\title{
A METALLURGICAL STUDY OF SOME VIKING SWORDS
}

\author{
ESTUDIO METALÚRGICO DE ALGUNAS ESPADAS VIKINGAS
}

POR

Alan Williams*

\section{Abstract - Resumen}

While «pattern-welded» swords have been found all over Europe from sites dating from the Migration Period and into the Early Middle Ages, they were steadily supplanted during the Viking period by swords made out of a few pieces of iron and steel, or even a single piece of steel. Swords with «Ulfberht» or related inscriptions were the most famous of these. The results of the metallurgical study of 44 specimens from «Ulfberht» swords, as well as some other Viking-age swords, together with electron microanalyses carried out on selected examples, are presented here.

Mientras que se han encontrado en toda Europa espadas forjadas mediante el sistema de 'pattern welding' (entrelazado de láminas formando patrones visibles), procedentes de yacimientos que se extienden desde el Periodo de las Migraciones bárbaras hasta la Alta Edad Media, durante el periodo vikingo fueron habitualmente reemplazadas por espadas forjadas a partir de unas pocas piezas de hierro y acero, o incluso de una única pieza de acero. Las más famosas de entre ellas fueron las espadas con la inscripción «Ulfbehrt» u otras relacionadas. Este artículo presenta los resultados del estudio metalúrgico de 44 ejemplares de espadas de «Ulfberht»y otras de época vikinga, así como los microanálisis efectuados sobre algunas muestras seleccionadas.

Key words - Palabras Clave

Metallurgy; metallography; crucible steel; Viking swords; Ulfberht» inscriptions.

Metalurgia; metalografía; acero de crisol; espadas vikingas; inscrpciones «Ulfberht».

\section{BLOOMERY STEEL AND CRUCIBLE STEEL}

During the early Middle Ages, the only ferrous material available for swords in Europe was «bloomery iron». This was the product of heating iron ore with charcoal in a small furnace. To oversimplify a complex series of reactions,

$$
\begin{gathered}
\text { Iron oxide }+ \text { carbon }=\text { carbon dioxide }+ \text { iron } \\
2 \mathrm{FeO}+\mathrm{C}=2 \mathrm{Fe}+\mathrm{CO}_{2}
\end{gathered}
$$

The iron ore was reduced to iron, but never melted, since the melting-point of pure iron is $1550^{\circ} \mathrm{C}$, and therefore never entirely separated from the slag formed by non-metallic impurities. The slag becomes liquid around $1100-1200^{\circ} \mathrm{C}$.

\footnotetext{
*Archaeometallurgist, The Wallace Collection, London. E-mail: armourmetal@ntlworld.com.
} 
Slags might also contain traces of the oxides of $\mathrm{Ca}$ (calcium) and $\mathrm{Mg}$ (magnesium) from the minerals associated with the ores, as well as traces of Mn (manganese) and Cr (chromium) as well as $\mathrm{K}$ (potassium) from wood-ash, as the fuel used was charcoal. The use of bog-iron ores might result in an iron high in $\mathrm{P}$ (phosphorus) which would harden the iron somewhat. Again, oversimplifying,

$$
\begin{aligned}
& \text { Silica (from sand, clay, etc) }+ \text { iron oxide }=\text { iron silicate (slag) } \\
& \qquad \mathrm{SiO}_{2}+2 \mathrm{FeO}=\mathrm{Fe}_{2} \mathrm{SiO}_{4}
\end{aligned}
$$

The lump (or «bloom») of iron formed might be forged out into swords which would still be full of slag inclusions. Parts of this iron bloom might absorb some carbon and thus become steel, but separating out the steel would have been extremely difficult. Producing it deliberately would have been almost impossible, at that time. Nevertheless, the large increase in hardness when steel is quenched would have made it attractive to try and select pieces of steel for the best weapons and tools. The hardness of pure iron is around 100 on the Vickers Pyramid Hardness (VPH) scale, the units of which are $\mathrm{kg} \cdot \mathrm{mm}^{-2}$. Absorbing enough carbon to form a $0.8 \% \mathrm{C}$ steel (called a eutectoid steel) might raise its hardness to about $250 \mathrm{VPH}$. But quenching this steel (plunging the red-hot artefact into cold water) might raise its hardness to 600 or even 800 $\mathrm{VPH}$, at the expense of increased brittleness. Successful heat-treatment might have involved gentle reheating («tempering») to reduce the hardness while increasing the toughness, but this process was extremely difficult to control, and heat-treatment was frequently avoided.

In China, the bloom was left in the furnace until it melted. Since the melting-point of steel falls with increasing carbon content, if it absorbs over $2 \% \mathrm{C}$, it will then melt at $1150^{\circ} \mathrm{C}$, forming a liquid called «cast iron». This may be cast into shape, but cannot be forged, and is of limited usefulness for making weapons.

However, a completely different approach, employed in India, Persia, and central Asia, was to make crucible steel. This was made by placing small pieces of iron in sealed crucibles packed with charcoal, or even pieces of cast iron, and heated (to around $1300-1400^{\circ} \mathrm{C}$ ) until it had absorbed enough carbon to wholly or partially melt into a cake of steel, and then allowed to cool extremely slowly. These ingots were exported to centres of arms manufacture where they were carefully forged, at a low temperature, into sword blades. Crucible steel was a highcarbon (about $1.2 \% \mathrm{C}$, but sometimes as high as $1.6 \% \mathrm{C}$ ) steel, called a hypereutectoid steel, which did not need any heat-treatment, since it already attained 300-350 VPH in hardness, nor did any amount of sharpening ever remove the edge. A much later development was a very slow-cooled ingot which preserved large crystals of cementite within the steel, which could then after etching generate a characteristic pattern («watered silk») on the surface of the blade. This was to be called wootz or «Damascus steel».

Several of these steels (in Group A) do not seem to have been homogeneous. If these steels were made by heating together iron and other substances in crucibles, there may well have been an intermediate stage when the charge was only partly melted. For example, a steel of $1.7 \% \mathrm{C}$ will not have a sharp melting-point but a «slushy» range of approximately 1200$1400^{\circ} \mathrm{C}$. Solidifying such a melt may well explain the heterogeneous nature of some of these specimens. Indeed, it may well have been several centuries before a temperature high enough and a time long enough were employed to form an entirely homogenous cast steel, and many more centuries before the production of wootz was mastered.

Nevertheless, even an imperfect crucible steel would have been considerably better than the fragments of bloomery steel which was all that was then otherwise available. 
What can be seen microscopically:

Ferrite crystals are pure iron, and appear as irregular white areas. Only the grain boundaries are actually visible. Hardness is $80-120 \mathrm{VPH}$. Pure iron does not harden on quenching.

Pearlite is a mixture of iron and iron carbide containing up to $0.8 \% \mathrm{C}$. It has a grey, lamellar appearance. It forms when steels are cooled in air after forging. Hardness up to 250-300 VPH.

Most steels (hypoeutectoid, below $0.8 \% \mathrm{C}$ ) are mixtures of ferrite and pearlite.

Martensite forms in quenched steels. It appears like laths, with some triangular symmetry. Hardness, depending upon C\%, varies from 200 to $800 \mathrm{VPH}$.

Bainite also may appear in quenched steels. It appears as a feathery or needle-like material. Hardness 200-400 VPH.

Cementite, iron carbide, $\mathrm{Fe}_{3} \mathrm{C}$, may be found as part of pearlite, or as separate areas in a network, or even appearing like needles, in hypereutectoid (above $0.8 \% \mathrm{C}$ ) steels, and also in cast irons (over $2 \% \mathrm{C}$ ). Hardness of cast iron might be $400 \mathrm{VPH}$, although pure cementite is much harder. Cast iron does not harden on quenching. In annealed («grey») cast irons, the cementite may break down into iron and carbon (as graphite).

\section{EARLY ANALYSES OF VIKING SWORDS}

Some very early quantitative analyses of Viking-age swords have been undertaken. Lorange ${ }^{1}$ took the view that the quality of a sword depended on its carbon content, so he had three patternwelded blades from Norway analysed (by T.N. Holme at Lillehammer) and their carbon contents were found to be $0.414 \% \mathrm{C}, 0.401 \% \mathrm{C}$, and $0.520 \% \mathrm{C}$. These did not include any Ulfberht swords. Some years later, a number of swords were analysed for Petersen ${ }^{2}$ by the engineer K. Refsaas, of Trondheim. He set about an extensive series of tests. Due to the condition of the swords he had to be content with samples of $1 \mathrm{~g}$ weight, which were analysed by direct combustion in a stream of oxygen. He was aware of the possible difference in composition between edge and blade, and for fragment 16276, for example, only the inner part with little carbon was preserved. He attempted to carry out 2 analyses, but in those specimens marked *, only one was possible.

Table of analyses of 9 swords from the Oslo University collection:

\begin{tabular}{c|c|c|c} 
INVENTORY NUMBER & FRAGMENT & CARBON CONTENT & TYPE \\
\hline 1977 & small fragment* & $0.48 \%$ & $\mathrm{D}$ \\
\hline 16276 & small fragment* & $0.20 \%$ & $\mathrm{D}$ \\
\hline 16519 & larger fragment* & $0.62 \%$ & $\mathrm{C}$ \\
\hline 13757 & larger fragment & $0.31 \%$ & $\mathrm{H}$ \\
\hline 14286 & $1 / 3$ sword $?$ & $0.67 \%$ & $\mathrm{~L}$ \\
\hline 4690 & $10 \mathrm{~cm}$ & $0.75 \%$ & $\mathrm{~S}$ \\
\hline 4979 & $15 \mathrm{~cm}$ & $0.46 \%$ & type20 \\
\hline 3983 & $9 \mathrm{~cm} *$ & $0.43 \%$ & $\mathrm{AE}$ \\
\hline 11056 & bar & $0.69 \%$ & $\bullet$
\end{tabular}

1 A. L. Lorange, Den yngre jernalders svaerd. Bergen, 1889.

J. Petersen, De norske vikingesverd. Kristiana, 1919. 
The highest carbon content $(0.75 \% \mathrm{C})$ of those tested was 4690 , an VLFBERH+T sword from Aker, Hedemarken. This has been examined again more recently (see below).

\section{«ULFBERHT» SWORDS}

There are around 100 swords with 'Ulfberht', or variants on this name, inlaid into the blade. These have been found scattered all over Northern Europe. The largest concentration is in Scandinavia and the Baltic Sea, although it has been suggested that if Ulfbehrt was their maker then on linguistic grounds the source of their manufacture should lie in the Rhineland ${ }^{3}$. From the different forms of these swords, Ulfbehrt would have been active for 300 years, so it has been suggested that perhaps this was a family of smiths rather than an individual, or the name was a trade mark of some sort. The analyses of some 44 of these swords are presented below.

For convenience, they are here divided into four groups, according to the spelling of their maker's name.

(Group A) +VLFBERH+T

(Group B) +VLFBERHT+

(Group C) variant spellings - on steel swords

(Group D) variant spellings - on iron swords

The inscriptions given are as read by the author, unless another attribution is quoted. Many of the swords in Norway were illustrated by Lorange (1889) but not all the letters he recorded seem to be visible now.

\section{$($ Group A) +VLFBERH+T swords}

1. Before the First World War, an «Ulfberht» sword $95.5 \mathrm{~cm}$ long with the inscription +VLFBERH+T was dredged from the Alster and given to the Museum for Hamburg History (M.1152, Type X, $11^{\text {th }}$ century). This was published, with an illustration, by Schwietering in $1915^{4}$ but then later an analysis (by one Dr. Schindler) was published in a Festschrift $t^{5}$. It was found to have a carbon content of $1.2 \%$. No other data was published, and the very high carbon content of a hypereutectoid steel was not remarked upon. Yet another «Ulfberht» sword, with a broken blade, found in the Elbe in 1957, is now in the same museum, and was published in 1970 by Müller-Wille. This also proved to be a hypereutectoid steel (see below).

Recent analyses.- Until recently, the use of hypereutectoid steels in Medieval Europe do not seem to have been recognised. But some years ago, this author analysed a broken sword in the stores of the Württemburg Landesmuseum with an «Ulfbehrt» inscription, and found it to be made of a hypereutectoid steel, of perhaps $1.4 \% \mathrm{C}$ or more (see below).

\footnotetext{
3 M. Müller-Wille, «Eine neue Ulfbehrt -schwert». Offa, 27(Neumunster, 1970): 65-91.

4 J. Schwietering, «Ein Ulfberhtschwert des 11 Jahrhunderts». Zeitschrift für Historische Waffen- und Kostümkunde, 7 (Berlin, 1915): 107-108.

5 H. Jankuhn, Festschrift für G. Schwantes. Hamburg, 1951: 212-229. Analysis of the Ulfberht sword is given on p. 224.
} 


\section{Württemburg Landesmuseum (WLM) Stuttgart, inv.no.1973-70 (Figs. 1-4)}

This was acquired at auction in 1973, having been found in the river Rhine at Karlsruhe, with the inscription +VLFBERH+T.

The microstructure taken from a half-section at the broken end, consisted of pearlite and cementite, some at grain-boundaries, and some in needle-like form. It is now evident that this was made from a billet of crucible steel (hypereutectoid) which had been folded twice and forged out into a blade (Williams, 1977). The presence of these cementite needles may have led to a certain brittleness in the blade, as its end had been broken off. This bore no resemblance to the microstructure of any other contemporary Western European sword so far observed, but Paul Craddock later suggested that the blade was made from a crucible steel which had undergone sufficient hot-work to obliterate traces of dendrites (although cementite needles are still present mixed with areas of pearlite); and indeed the section suggests that it was folded from a billet in the course of forging out the sword.

\section{Oslo Historisk Museum c.4690 (Figs. 5-11)}

It has an inscription which may be read as + VI F B E R H + T.

Average surface hardness (body) 130-180 VPH (nearer edges) 220-310 VPH.

An analysis of samples from this sword (by Refsaas) was published in Petersen (1919). The cavities left by his sampling are still visible on the surface of the blade. They were taken from the middle of the blade, which might explain why the carbon content in the published analysis $(0.75 \% \mathrm{C})$ does not tally with that expected from the microstructure of the edge.

A sample was taken from the edge, at the broken end of the sword tip.

The microstructure consists mostly of pearlite, in areas surrounded with a network of cementite. In places, this cementite appears as laths within the areas of pearlite; in other places, the network has broken up into globules. There are a few slag inclusions. In parts, away from the edge, there are areas of ferrite also. These seem to become more frequent as one moves towards the areas from where the samples were taken.

This appears to be a hypereuctectoid steel, in places, which has undergone considerable hot-working (or even perhaps a deliberate anneal to soften it) which has caused the cementite to spheroidise in some parts. This may also have led to surface decarburisation, deliberately or accidentally. This may explain why the carbon content, according to combustion analysis of samples away from the edge, is only $0.75 \% \mathrm{C}$; but away from the surface, according to the microstructure, it is well over $1.0 \% \mathrm{C}$.

WDX microanalysis: The carbon content from point analyses varied from $0.59 \%$ to $2.33 \%$. An average of 15 points gave $1.4 \% \mathrm{C}$, which is in accordance with the microstructure here.

\section{Bergen Historisk Museum 882 (Figs. 12-17)}

It has an inscription which may be read as V L F B E R H +...

[Read as VLFBERH+T by Lorange] Average surface hardness 180-220VPH. Three specimens were taken:

(i) A specimen from the body of the sword was examined. The microstructure consists of areas of fine pearlite, with a network of cementite, and no visible slag inclusions. This is a hypereutectoid steel of carbon content at least $1 \%$.

Microhardness range 253-308 VPH (average $=282$ ). 
(ii) Two smaller flakes from the edge were also examined. The microstructure of one consists of areas of fine pearlite, with some ferrite grains near the surface, and no visible slag. The microstructure of the other consists of areas of fine pearlite, with a network of cementite and some ferrite grains near the surface. There are also some unusual features, which on repolishing and re-examination at a higher magnification, turned out to be cavities, some of which still contain graphite flakes, and some of which are empty. In the surrounding area, the microhardness is higher there. This would appear to be the relic of an area of very high carbon content, which has contained primary graphite. If this was made from an ingot of crucible steel, then one of the ingredients of the crucible was a cast iron. This is reminiscent of al-Biruni's $11^{\text {th }}$ century description of the production of crucible steel in Herat ${ }^{6}$.

Local decarburisation near the surface might have occurred during forging. Microhardness range 226-279 VPH.

(iii)A sample was also taken from an inlaid letter. The microstructure of this consists of ferrite (in large equiaxed grains) and very elongated slag inclusions only. This suggests that the inlay was applied hot during forging, rather than hammered into the blade afterwards when cold.

WDX microanalysis: The carbon content from point analyses in the middle of sample (ii) varied from $1.72 \%$ to $8.96 \%$. However, avoiding primary graphite, an average of 9 points gave $2.7 \% \mathrm{C}$. This suggests an area which originated as cast iron.

\section{Bergen Historisk Museum 1483 (Figs. 18-20)}

Only part of the inscription can now be read: ...H $+\mathrm{T}$. [Read as VLFBERH+T by Lorange]

The microstructure consists of areas of fine pearlite, with a network of cementite, and only very few slag inclusions. This is a hypereutectoid steel of carbon content at least $1 \%$.

Microhardness range 295-360; average $=327 \mathrm{VPH}$.

WDX microanalysis: The carbon content from point analyses varied from 1.22 to $2.69 \%$, but, avoiding dendrites, an average of 6 points gave $1.3 \% \mathrm{C}$, which accords with the microstructure.

\section{Bergen Historisk Museum 3149 (Figs. 21-23)}

It has an inscription which may be read as V L F B E R + H T or V L F B E R H + T [read as V L F B E R H H T by Lorange].

Average surface hardness was $240 \mathrm{VPH}$ (the hilt was $107 \mathrm{VPH}$ ) - two specimens were taken:

(i) From the edge

The microstructure consists of areas of fine pearlite, with numerous small equiaxed grains of ferrite, and very few inclusions, which are not elongated, but there is no cementite network. This area is a medium-carbon steel of perhaps $0.5 \%$ overall. Local decarburisation must have occurred during forging. A low forging temperature might explain the small ferritic grain size.

Microhardness range 220-274; average $=231 \mathrm{VPH}$.

(ii) From the body

6 R. G. Hoyland \& B. Gilmour, Medieval Islamic swords and Swordmaking. Oxford, 2006: 148-174. 
The microstructure consists of areas of fine pearlite, outlined with a network of cementite, and no visible slag inclusions. This part is a hypereutectoid steel of carbon content at least $1 \%$, which has been subsequently annealed.

Microhardness (Vickers, 100g load) range 204-286 VPH.

The lower carbon content of the edge may be the result of an imperfectly melted and homogenised crucible steel, or decarburisation due to excessive hot-working.

WDX microanalysis: The carbon content from point analyses varied from $1.09 \%$ to $6.19 \%$. An average of 9 points gave $1.7 \% \mathrm{C}$, if the $\mathrm{Fe}_{3} \mathrm{C}$ dendrites were avoided altogether.

\section{Museum für Hamburg Geschichte; inv.no.1965/124 (Fig. 24-25)}

Inscription +VLFBERH+T. Another river find, from the Elbe.

A sample taken from the damaged edge about $10 \mathrm{~cm}$ from the end, shows a microstructure of mostly fine pearlite with some cementite at grain boundaries, but no visible slag inclusions. Another taken from near the centre, at the broken tip, shows a microstructure of very fine pearlite. This is a steel of perhaps $1 \%$ carbon, or more, and so it is almost certainly a hypereutectoid steel.

Microhardness centre 337-388; average $=355$ VPH. - edge 439-476; average $=463$ VPH.

It seems that this blade underwent more hot-working than sword \# 2, and perhaps had a lower carbon content, for no cementite was observed in the form of needles within the prior austenite grains, but only at grain boundaries, or as laths, in a more equiaxed form. By contrast, the sword \# A 8 seems to have undergone a little too much hot working.

Electron microanalysis suggests that the inclusions are iron oxide.

\section{Solingen, Deutsche Klingenmuseum; inv.no.1973.w.5 (Figs. 26-27)}

It has an inscription which may be read as +VLFBERH+T.

A sample taken from the damaged edge shows a microstructure of what seems to have been pearlite which has been mostly divorced into carbide particles, and a network of particles outlining the prior pearlitic areas. There are very few slag inclusions ${ }^{7}$.

Microhardness 243-277; average $=258 \mathrm{VPH}$.

This seems to be a steel which has been annealed, or undergone an excessive amount of hot-working. Since it seems unlikely that any sword would be intentionally softened by annealing, one may speculate that this was another hypereutectoid steel but it was somewhat overheated in working.

\section{Helsinki Kansali Museum 9164:3 (Figs. 28-29)}

From Eura. It has an inscription which may be read on one side as +VL F ...E R H +T and on other side ||$|X|||$, where $\mathrm{X}$ is within a hexagonal shape ${ }^{8}$; the character between $\mathrm{F}$ and E might be read as $\mathbf{b}$ or a distorted $\mathrm{B}$.

7 A. Williams, «Crucible steel in medieval swords», S. LaNiece, D. Hook and P. Craddock, Metals and Mines. London, 2007: 233-241.

8 J. Leppäaho, Späteisenzeitliche waffen aus Finland. Helsinki, 1965: 12. This book of illustrations of blades was posthumously published as Finska Fornminnesföreningens Tidskrift, 61 . 
The microstructure shows large areas of pearlite, of a feathery appearance, and almost irresolvable. There are no visible slag inclusions, nor areas of ferrite.

Microhardness range 417-476; average $=447 \mathrm{VPH}$.

The absence of slag inclusions may be significant. If this is another hypereutectoid steel, that has undergone some form of accelerated cooling, to form irresolvable pearlite (or perhaps even upper bainite) then the absence of visible proeutectoid cementite might be explicable.

Samuels ${ }^{9}$ shows a photomicrograph of a $1.0 \% \mathrm{C}$ steel which has been isothermally transformed at $450^{\circ} \mathrm{C}$ for 1 minute to produce a fine pearlite/bainite microstructure with a hardness of $425 \mathrm{VPH}$.

A similar microstructure is also shown in some $17^{\text {th }}-18^{\text {th }}$ century Indian swords from Hyde$\operatorname{rabad}^{10}$; one specimen showing very fine pearlite of $370 \mathrm{VPH}$. This is presumed to have been made much later from another crucible steel.

\section{Helsinki Kansali Museum 2548:839 (Figs. 30-31)}

From Laitila. It has an inscription which may be read on one side as +VLFBERH+T and on the other side ||$|X|||$ with $X$ within an ovoid (as read by Leppäaho ${ }^{11}$, although this does not now seem to be visible).

The microstructure shows large areas of pearlite, lamellar in some places, but irresolvable in others. Some ferrite is present near one end of the sample as equiaxed grains, and in other places within the pearlite areas in a Widmanstätten formation.

There are also a number of large, irregular, slag inclusions.

This is a rather unusual microstructure, but it seems to be a steel of varying carbon content which has undergone a rapid air-cool.

Microhardness range 236-286; average $=269 \mathrm{VPH}$.

\section{A sword from a private collection (Figs. 32-34)}

Hemispherical pommel decorated with inlay - unclear inscription but found by subsequent X-radiography to read +VLFBERH+T - perhaps 1000CE.

The microstructure consists of a very uniform mixture of very small grains of ferrite, mixed with areas of very fine pearlite irresolvable in place (and perhaps $0.5 \% \mathrm{C}$ overall) with no visible inclusions.

This is a notably uniform medium-carbon steel which has been quickly air-cooled after fabrication. It is possible that it is also a crucible steel in origin.

Microhardness range $=279-322$; average $=297 \mathrm{VPH}$

\section{Virumaa Museum, Rakvere, Estonia RM 587/A21 (Figs. 35-38)}

It bears an inscription which may now be read as (.....) F B E R H + T but was read as +VL F B E R H + T by Anteins ${ }^{12}$, with the V and L joined.

\footnotetext{
9 L. E. Samuels, Light microscopy of carbon steels. Ohio, 1999: 266-269.

10 "The metallurgy of some Indian swords from the Arsenal of Hyderabad and elsewhere» (with D. Edge) Gladius, 27 (Madrid, 2007): 149-176.

11 Leppäaho, op. cit.: 46,

12 A. K. Anteins, Damascene steel in the lands of the Baltic Sea Basin. Riga, 1973: 44.
} 
The inlaid letters are formed of pattern-welded strips. The blade may have been annealed, and there is a fracture (the result of a cremation ?) half way down the blade. Surface hardness of the blade was 160-320 VPH, the pommel was 130-150 VPH.

Two samples were studied:

(i) A sample from the edge $15 \mathrm{~cm}$ from the hilt.

Metallography: the microstructure consists largely of areas of pearlite with some ferrite grains, and very few slag inclusions. The carbon content is around $0.6 \%-0.8 \%$.

(ii) A half-section detached where the blade was already fractured.

Metallography: the microstructure shows an area with more ferrite near the surface than in the centre. There does not seem to be any trace of a weld, although there are a number of small, elongated slag inclusions. Otherwise it is a fairly uniform pearliticferritic steel, with carbon content varying between $0.4 \%$ and $0.9 \%$. The pearlite is broken up in a way characteristic of annealing. Cremation may have caused some surface decarburisation, but only within a fairly narrow layer. The hardness ranges from 150 to $200 \mathrm{VPH}$.

\section{Estonian History Museum, Tallinn A.580:2020 (Figs. 39-41)}

Sword excavated in 1985 from a cremation site at Maidla, Western Estonia. The sword has been rolled up into a coil.

It had apparently been polished and etched by Antiens, but subsequent corrosion had obscured the inscription. However, it was repolished by the Conservation Department, and the inscription became partially visible again. Traces of copper appear on the inlaid letters. It may be read as (doubtful letters in brackets)

$+(\mathrm{L}) \mathrm{F}(\mathrm{B}) \mathrm{E}(\mathrm{P}) \mathrm{H}+(\mathrm{I}) \quad$ although it was read as VLFBERHT by Mandel ${ }^{13}$.

Surface hardness 150-170 VPH. A sample was detached from the broken edge, $4 \mathrm{~cm}$ from the end of the blade.

Metallography: the microstructure consists of fine pearlite with some ferrite grains arranged in bands. The carbon content reaches between $0.6 \%$ and $0.8 \%$. There is a large corrosion crack visible. Cremation may have caused some surface decarburisation, but only within a fairly narrow layer, despite its history.

Microhardness; ranges from 178 to 246; average $=197 \mathrm{VPH}$.

\section{A sword from a private collection (Fig. 42-45)}

It has an inscription (which is unusually clear, perhaps due to over-cleaning in the past) which may be read as +VLFBERH+T.

A sample taken from the upper edge has the microstructure of an unusual mixture of areas of ferrite and carbides, which resembles somewhat an overtempered martensite, a large lump of iron oxide, and an area of ferrite and pearlite with grains of cementite and small, ovoid, slag inclusions. This is very heterogeneous and may perhaps have been the result of attempting (but failing) to completely melt a crucible steel.

13 M. Mandel, «Typology and dating of Estonian swords of the $8^{\text {th }}-13^{\text {th }}$ centuries». Muinasaja Teadus I (Tallinn, 1991): 126-130. 
The carbon content varies between around $0.8 \%$ and $1 \% \mathrm{C}$. Some of the pearlite areas are lamellar, and some are irresolvable. After forging, it may have been given some sort of accelerated cooling to harden it. The precise nature of the heat-treatment is difficult to discern, as an overtempered martensite will resemble a hot-worked crucible steel.

Microhardness range 308-345; average $=321 \mathrm{VPH}$.

Electron microanalysis. The metal matrix is virtually pure iron. Some elongated inclusions of iron silicate (with Mn, K) a typical bloomery slag. There is another inclusion high in Si (possibly from the furnace lining?).

Out of these 14 swords, 9 are made of hypereutectoid steels, or steels hypereutectoid in places. The carbon content of a tenth (\#9) cannot be determined, but was probably at least eutectoid. Of the remainder, two specimens (\#12 and \#13) are partly eutectoid although they are from cremation burials. And one specimen (\# 11) is not eutectoid, but is very uniform in microstructure.

So most of these could have been made from crucible steel, whatever the source of that might have been. No swords from any of the other groups were made from hypereutectoid steels.

$($ Group B) +VLFBERHT + swords

When other «Ulfberht» swords with the same spelling of the inscription but with the cross after the letter T (that is +VLFBERHT + ) are examined, we find that their metallurgy is different to those of Group A but similar to one another.

\section{Olomouc Regional Museum, Czech Republic. (Fig. 46)}

A sword from a $10^{\text {th }}$ century grave at Nemilany, with the inscription +VLFBERHT + .

It was examined by the staff of the Conservation Laboratory of the Brno Technical Museum $^{14}$. It has a core of low carbon content $(<235 \mathrm{VPH})$ and welded-on steel cutting edges, hardened to $320-460 \mathrm{VPH}$ by quenching .

\section{Helsinki Kansali Museo 18402:1c (Figs. 47-48)}

\section{+V L F B E R H T+}

Average surface hardness $=210-220$ (tang 110) edge 310-390 VPH.

The microstructure of a sample from the edge consists of uniform tempered martensite, with a few slag inclusions. There appear to be no separate grains of ferrite, nor areas of pearlite.

Microhardness range 388-476; average $=437 \mathrm{VPH}$.

The low surface hardness of the body suggests that this was made of iron, which will not harden on quenching.

Electron microanalysis. The metal matrix is virtually pure iron. There are some elongated inclusions of iron silicate (with $\mathrm{Mn}, \mathrm{Ca}, \mathrm{Mg}, \mathrm{Al}, \mathrm{K}$ ) and some smaller, rounder, ones of iron silicate (some without K). Perhaps these may have come from the 2 different metals employed.

14 A. Selucká, A. Richtrová \& M. Hložek, Konservace železného meče Ulfberht, Sbornik z konservátorského a restaurátorského semináře. České Budějovice, 2001: 65-68 and 103-104. 


\section{Bergen Historisk Museum 1165 (Figs. 49-50)}

\section{L F B E R ++ [read as VLFBERHT+ by Lorange]}

The microstructure consists of uniform very fine pearlite, feathery in some areas, and irresolvable in others. No separate ferrite grains are visible, but there are a few slag inclusions. This is a steel of perhaps $0.5 \% \mathrm{C}$, which appears to have undergone some form of accelerated cooling after forging.

Microhardness range 234-261; average $=250 \mathrm{VPH}$.

\section{Helsinki Kansali Museo 10390:2 (Figs. 51-53)}

With inscription on one side +VLFBERHT $+{ }^{15}$.

The microstructure shows a mixture of pearlite areas and ferrite grains both as a network and within the pearlitic areas. The latter grains are equiaxed rather than spiny in their formation. It is difficult to decide the previous heat-treatment, but it could have been a Widmanstätten microstructure in a steel which has undergone considerable subsequent hot-working. The overall carbon content seems to be about $0.5 \%$. Microhardness range 116-223 VPH.

\section{A sword from a private collection (Figs. 54-56)}

Possibly $9^{\text {th }}$ century. A sword with the inlay of pattern-welded metal forming the letters RHT+.

One sample had only ferrite and some circular slag inclusions.

Another sample (taken from nearer the edge) was also taken and the microstructure consists of a fairly uniform mixture of areas of nodular pearlite mixed with lightly tempered martensite (perhaps $0.5 \% \mathrm{C}$ ) and some small grey slag inclusions.

This is a medium-carbon steel which has been hardened by slack-quenching. It may well be that only the cutting edges were made of steel.

Microhardness range $=264$ (pearlite)-564 (martensite); average $=378 \mathrm{VPH}$

Electron microanalysis. The metal matrix is virtually pure iron. There are some elongated inclusions of iron silicate (with $\mathrm{Ca}, \mathrm{Mn}$ ) a typical bloomery slag. Some of these contain 2 visible phases. There are also some irregular lumps (with $\mathrm{Mg}$, high $\mathrm{Si}$ ) which are possibly slagged furnace lining.

Of these swords in Group B, 3 out of 5 have fully hardened edges, while the others one has steel edges which have undergone some sort of heat-treatment, albeit not a very successful ones.

The similarity of their manufacture, the hardnesses attained, as well as the variant spelling, together suggest that they may well have come from the same workshop, which was endeavouring to copy the high-carbon blades of the original «Ulfberht» workshop. One possible way would have been by welding small pieces of bloomery steel onto a billet of iron, and forging that into a blade before quenching it. The sharp edge that could be formed might well fool the less discerning customer, but with a depth of only a few millimetres it would not have survived many sharpenings. It would have been very tempting to try and counterfeit these valued blades, and many other workshops seem to have followed similar methods, which were already well-established in Europe.

15 Leppäaho, op. cit.: 42. 
(Group C). Swords MAdE WITH VARIANT SPELLINGS OF THE INSCRIPTION VLFBERHT - WITH HARDENED STEEL EDGES

\section{A sword in a private British collection ${ }^{16}$ (Figs. 57-60)}

This had a very worn inscription which might be read as VLFBERN+T.

The microstructure consists largely of ferrite with a layer of martensite corresponding to a cutting edge approximately $6 \mathrm{~mm}$ deep. Evidently a thin layer of (perhaps $0.5 \% \mathrm{C}$ ) steel was wrapped around a much larger piece of iron, or low-carbon steel, and attached by forgewelding. This composite billet was then forged out into a sword-blade and hardened by quenching. This gave a hard $(423-540$, average $=467 \mathrm{VPH})$ edge on a much less hard core (236 $\mathrm{VPH})$. Its resemblance to sword \#1 in Group B above is conspicuous.

\section{A sword found in the Danube at Abbsbach and now in a private collection ${ }^{17}$ (Figs. 61- 63)}

It has the inscription + VLFBERH $+\perp$ with the final $\mathrm{T}$ inverted.

A sample taken from the upper edge (near the end of the inscription) has a microstructure which consists of areas of carbides, which have a feathery appearance in places (probably bainite). No free ferrite or pearlite is visible. This seems to be a low/medium-carbon steel which has been given an accelerated cooling to harden it. There is no way of knowing whether this is an all-steel blade, or whether only the edges are steel.

Microhardness range 295-322; average $=307 \mathrm{VPH}$.

Electron microanalysis. Metal matrix virtually is pure iron with a trace of $\mathrm{Cr}$. There are very few, small, inclusions, one of which is of iron silicate. Others are apparently also of iron silicate but very high in Si (probably because all the iron oxide has been reduced from the iron silicate by the adjacent carbon).

\section{Germanisches National Museum, Nürnberg FG.2187 (Fig. 64-66)}

A sword with the inscription +VLFBEH+T

A sample was taken from the middle of the broken end. The microstructure consists of very fine pearlite, irresolvable in places, with a little proeutectoid ferrite, spiny in places. There are very few slag inclusions. This is a medium-carbon steel (around $0.7 \%-0.8 \% \mathrm{C}$ ) which has been given an accelerated cooling after forging, such as for example, a lead quench.

Microhardness range 286-345; average $=310 \mathrm{VPH}$

Electron microanalysis. The metal matrix is virtually pure iron. There are some elongated inclusions of iron silicate (with $\mathrm{Ca}, \mathrm{P}$ ) and some smaller ones of iron silicate (with $\mathrm{Mn}$ ).

\section{Wisbech \& Fenland Museum; inv.no.1860.5 (Figs. 67-70)}

This sword has the inscription $+\mathrm{V} \Gamma$ EBERHTC+ (with $\mathrm{L}$ and $\mathrm{F}$ inverted) on one side and another inscription INGEFLRII, on the other side.

16 D. Edge \& A. Williams, «Some early medieval swords in the Wallace Collection and elsewhere». Gladius, 23 (Madrid, 2003): 191-210.

17 E. Szameit, «Ein VLFBERHT-Schwert aus der Donau bei Aggsbach, Niederösterreich». Archaeologia Austriaca, 76 (Wien, 1992): 215-221. 
A sample was detached from a damaged edge, at about $8 \mathrm{~cm}$ from the tip.

The microstructure consists of tempered martensite, without free ferrite or pearlite visible.

Microhardness (Vickers, 100g load) 329-379; average $=356 \mathrm{VPH}$

So this is a sword whose steel edges have been hardened by a successful heat-treatment. It is not possible without sampling the interior of the blade, to know whether the body of the sword was made of iron, with steel edges welded on, or whether it was all made of steel. This sword has been described and illustrated recently ${ }^{18}$.

\section{Helsinki Kansali Museo 6066:1 (Figs. 71-72)}

With an inscription on one side $\quad$ V......T (intermediate letters might include L and B) and on the other side ||$|X X|||$, where the two X are interlaced (reading of Leppäaho, 44). Average surface hardness $=330-380 \mathrm{VPH}$.

The microstructure shows a mixture of ferrite and martensite, in bands, without any visible pearlite, and a few slag inclusions. This sword had a steel edge, possibly welded onto an iron core, although there is no row of slag inclusions along the boundary between the ferrite and martensite. The sword was subsequently hardened by a full quench.

Microhardness range 261-429; average $=350 \mathrm{VPH}$.

Electron microanalysis. The metal matrix is virtually pure iron. There are some inclusions of iron silicate (with Mn) and some of iron silicate (without Mn).

\section{Saaremaa Museum, Estonia K85-108 (Figs. 73-76)}

Three VLFBERHT swords which all came from the island of Saaremaa, and which were stored in the Institute of History, Tallinn University, are now back in the Saaremaa Museum, housed in Kuressaare Castle. Traces of silver are left on the hilt and pommel. The inscription is very unclear, but the letters $(\ldots \ldots.) \mathrm{B} \mathrm{E}(\ldots)+$. may be discerned. Anteins ${ }^{19}$ read this as + VLFBERH+

The surface hardness was 170-220 VPH in the centre. Two samples were detached:

(i) From the broken end near the tip

Metallography: the microstructure appears to consist of ferrite and slag only.

This sword was evidently made with an iron core and steel edges.

(ii) From the edge, halfway down the blade $(92 \mathrm{~cm})$

Metallography: the microstructure consists of a very uniform mixture of fine carbides, apparently divorced pearlite and an acicular material, probably bainite. There are no slag inclusions visible, nor separate grains of ferrite. This sword was made from steel edges welded onto an iron body, and then was given some sort of heat treatment to form a mixture of fine pearlite and bainite, which was finally tempered.

Microhardness (edge); range 230-248; average $=240 \mathrm{VPH}$.

18 M. R. Gorman, «Ulfberht: innovation and imitation in early Medieval Swords». The XVIth Park Lane Arms Fair Catalogue (1999): 7-12.

19 Op. cit.: 44. 
STEEL SWORDS (UNHARDENED) MADE WITH VARIANT SPELLINGS OF THE INSCRIPTION VLFBERHT

7. Saaremaa Museum, Estonia. K85-122 (Figs. 77-82)

This is a blade without a hilt. It has been polished in the past, but only a few letters can be discerned. + (NN) (....) (P) E ...H...

$\mathrm{P}$ might be $\mathrm{B}$ and NN might be a joined VL. Length $96 \mathrm{~cm}$.

Anteins ${ }^{20}$ read the inscription as + VLBERHT + (and the + are Latin crosses and do not resemble the + on swords described above)

Three samples were detached:

(i) The edge $1 \mathrm{~cm}$ from the tip

Metallography: the microstructure consists of divorced pearlite in small areas with very little slag. There are no separate ferrite grains.

Microhardness; range 234-266; average $=252 \mathrm{VPH}$.

(ii) The edge $20 \mathrm{~cm}$ from the tip

Metallography: the microstructure consists of slightly divorced fine pearlite with some isolated ferrite grains.

Microhardness; range 210-234; average $=217 \mathrm{VPH}$.

(iii) The rim of the central hole.

Metallography: the microstructure consists of a mixture of ferrite and pearlite with some elongated slag inclusions. The carbon content is $0.4 \%-0.5 \%$. The higher carbon content of the edges is probably intentional.

Microhardness; range 137-185; average $=158 \mathrm{VPH}$. The final heat-treatment seems to have been annealing.

8. Saaremaa Museum, Estonia K85-120 (Figs. 83-85)

A hemispherical element seems to be missing from the end of the pommel ${ }^{21}$.

Length $68 \mathrm{~cm}$, with traces of a crack $10 \mathrm{~cm}$ from the end.

The inscription may be read as + VL F B E R H + (T) with the initial V \& L joined. Anteins $^{22}$ read the inscription as +VLFBERHI .

A sample was detached from the edge $20 \mathrm{~cm}$ from the tip.

Metallography: the microstructure consists of a very uniform mixture of small grains of ferrite and areas of divorced pearlite, with very few slag inclusions. (The author wonders whether, if this is significant, this sword should have been placed in the first category) The carbon content varies between $0.3 \%$ and $0.6 \%$.

Microhardness; range 189-217; average $=205 \mathrm{VPH}$.

\section{Bergen Historisk Museum 2944 (Figs. 86-88)}

This sword was found damaged and bent somewhat at the end. It has an inscription [read as VLFBERHCT by Lorange].

20 Op. cit.: 44

${ }_{21}$ M. Ebert, «Ein Schwert mit tauschierte Klinge von Lümmada auf Oesel», Baltische Studien zur Archäologie und Geschichte. Berlin, 1914: 147-158. He illustrates a sword (without an inventory number, then in the Arensburger Museum, Oesel) which could be this one, if the end of its pommel has since been lost. The inscription is recorded there as +VLFBERH+ apparently without a final T. It should be noted that the German name for Saaremaa was Oesel.

22 Op. cit.: 44. 
The microstructure of a specimen from the body consists of ferrite mixed with pearlite completely divorced (to iron carbide); there is some trace of a prior pearlitic structure in places. This was probably a ferrite/pearlite steel, whose carbon content varied between perhaps $0.2 \%$ and $0.8 \%$, before it was annealed.

Microhardness range 163-289; average $=215 \mathrm{VPH}$

\section{Helsinki Kansali Museum 3601:2 (Figs. 89-91)}

This sword was found bent double. It has an inscription on one side

+ V L F B E R H ++ and on the other side X within a lozenge ${ }^{23}$.

The microstructure shows a mixture of ferrite and globular carbides. At higher magnification, it is apparently fairly uniform pearlite which has been almost completely divorced. There are also a few slag inclusions.

This seems to be a medium-carbon steel (perhaps $0.5 \%-0.6 \% \mathrm{C}$ ) which has undergone a prolonged annealing. It view of the fact that the sword was found bent double, this would seem to be the explanation for such an unsuitable microstructure. Traces of a prior lamellar arrangement suggest that the original microstructure may have been pearlitic rather than martensitic, but this cannot now be confirmed.

Microhardness range 195-217; average $=208 \mathrm{VPH}$.

\section{Bergen Historisk Museum 2695 (Figs. 92-93)}

It has an inscription of which F...T can still be discerned $\quad$ read as VLFBERHH by Lorange]. Average surface hardness $=188 \mathrm{VPH}$.

A specimen was taken from the edge of the blade. The microstructure shows mostly fine pearlite with some ferrite grains in a network, and some within the pearlite areas. The overall carbon content is perhaps $0.6 \%$.

Microhardness (edge) range 175-243 VPH.

A specimen was also taken from the centre of the blade. The microstructure (not shown) of this specimen consists of equiaxed ferrite grains and areas of pearlite as well as some fairly large slag inclusions. The overall carbon content is around $0.4 \% \mathrm{C}$. Although no attempt has been made to harden the blade, the higher carbon content of the edge is probably intentional.

Microhardness (centre) range 160-215 VPH.

\section{Bergen Historisk Museum 1069 (Figs. 94-95) (Sword not shown)}

It has an inscription $\mathrm{H} \Gamma \mathrm{X}$ I N T + (broken-up letters which perhaps were a copy of Ulfberht). Average surface hardness $=210 \mathrm{VPH}$

The microstructure shows mostly pearlite with a few ferrite grains, and very few slag inclusions. The overall carbon content is perhaps $0.6 \%$.

Microhardness range 226-279 VPH.

\section{Bergen Historisk Museum 3993 (Figs. 96-97)}

The end is broken off; it has an inscription which may be read + I I E....

Average surface hardness $=130-160 \mathrm{VPH}$.

\footnotetext{
23 Leppäaho, op. cit.: 46.
} 
The microstructure shows mostly pearlite with a few ferrite grains, and very few slag inclusions. The overall carbon content is perhaps $0.6 \%$.

Microhardness range 199-264 VPH.

\section{Bergen Historisk Museum 1622 (Figs. 98-100)}

This has an inlaid hilt, and an inscription which seems to read now .... B R T (but it was read as THURMUTH by Lorange).

Two specimens were taken:

(i) A specimen from the centre of the blade shows a microstructure of ferrite and slag only (not shown). Microhardness (Vickers, 100g load) range 119-163 VPH

(ii) A specimen from the edge of the blade shows a uniform microstructure of pearlite, which has been largely divorced (to cementite) by heating, together with some slag inclusions. There do not seem to be any separate areas of ferrite grains. This is a steel of around $0.8 \% \mathrm{C}$ which has been annealed; for what reason can only be conjectured. Microhardness (Vickers, 100g load) range 204-305; average $=231 \mathrm{VPH}$.

(Group D). IRON SWORDS MADE WITH VARIANT SPELLINGS OF THE INSCRIPTION VLFBERHT

1. Helsinki Kansali Museum 6503:20 (Figs. 101-102)

From Tyrväntö. It has an inscription on one side +V L ..B E R H $+\mathrm{T}$ and on the other side ||| IXI |||, where $\mathrm{X}$ is within a lozenge ${ }^{24}$. The character between $\mathrm{L}$ and $\mathrm{B}$ might be a distorted $\mathrm{F}$, but to this author, resembles $\Gamma$.

The microstructure shows bands of ferrite and very few carbides, with another band of ferrite and slightly more pearlite (but less than $0.2 \% \mathrm{C}$ in this band). This contains a few elongated slag inclusions, and also pearlite which seems to be associated with slag in some places (perhaps a weld).

Microhardness range 148-171; average $=161 \mathrm{VPH}$.

\section{Bergen Historisk Museum 1484 (Figs. 103-105)}

This is a blade without a hilt or pommel. It has an inscription of which only

...F V ... can now be read. Average surface hardness $=200 \mathrm{VPH}$

The microstructure shows a uniform ferrite-carbide aggregate, apparently the result of (over-) tempering a low-carbon martensite.

Microhardness (Vickers, 100g load) range 195-217; average $=209 \mathrm{VPH}$.

The low hardness suggests that this was only around $0.2 \%-0.3 \% \mathrm{C}$, although the smith evidently believed that it was a better steel.

Electron microanalysis. The metal matrix is virtually pure iron. There are very few, and small inclusions apparently of iron silicate but high in $\mathrm{Si}$ (with $\mathrm{Mn}, \mathrm{Ca}, \mathrm{Mg}, \mathrm{Al}, \mathrm{K}$ and $\mathrm{P}$ ) and some with Ti also. Some of these are very small (around $1 \mu$ ) yet high in Mn.

24 Ibid: 46 . 
3. Helsinki Kansali Museo 2767 (Figs. 106-107)

From Sääksmäki. It has an inscription on one side which was read by Leppäaho ${ }^{25}$, as

V L F B E (R)H +.. and on the other side ||$|\ni+C|||$ (where + is a Latin cross).

The end of the blade is broken off after + , and the letters between $\mathrm{B}$ and $\mathrm{H}$ cannot now be distinguished. Average surface hardness $=166-236 \mathrm{VPH}$.

The microstructure shows bands of ferrite and ferrite with some pearlite, which appears very coarse (overall less than $0.2 \% \mathrm{C}$ ) The central band seems to be carbon- free. There is lots of inter-granular corrosion and some elongated slag inclusions.

Microhardness range 189-207; average $=196 \mathrm{VPH}$.

\section{Pitt-Rivers Museum, Oxford (Fig. 108)}

(inv.no.1555.2580; on loan to the Ashmolean Museum).

The inscription may be read as $+\mathrm{VI}_{7}$ IFR I $+\perp$.

A sample was detached from a damaged edge, near to the letter R. The microstructure consists of ferrite, with a few slag inclusions.

Microhardness (average) $=143 \mathrm{VPH}$.

It may be hypothesised that this blade did have a hard steel edge at one time, but that repeated sharpening has removed this edge, leaving the iron core. This might perhaps be a reason why the blade has been bent, and seems to have undergone fire damage. This sword has been described and illustrated recently ${ }^{26}$.

\section{Bergen Historisk Museum 946 (Figs. 109-110)}

To this author only ..R $\mathrm{T}$...of the inscription is visible [although it was read as VLFBERH+T by Lorange]

The microstructure consists of ferrite mixed with a little pearlite. There is a band visible where the pearlite seems to have been reduced in quantity and broken up into smaller areas; this may well be a fold line from forging. There are some slag inclusions. The overall carbon content is only around $0.1 \%$.

Microhardness range 165-236; average $=204 \mathrm{VPH}$.

\section{Bergen Historisk Museum 3315 (Figs. 111-112)}

It has an inscription of broken-up letters which perhaps were a copy of VLFBERHT.

$\dashv \mid\left\ulcorner\mid T T^{\lrcorner \perp}+\right.$ Average surface hardness $=230-240 \mathrm{VPH}$.

A specimen from the edge of the blade shows a microstructure of ferrite and slag. This metal would have made a very poor sword indeed.

25 Ibid.: 36.

26 I. Pierce, «A newly identified Ulfberht inscribed sword in the Ashmolean Museum, Oxford». The Spring 2004 Park Lane Arms Fair Catalogue, 2004: 14-15. 
7.Helsinki Kansali Museo 10390:5 (Figs. 113-114)

From Vesilahti. It has an inscription on one side +VLEHRAH LN++ where AH are conjoined and the terminal $\mathrm{LN}+$ are conjoined, and on the other side || $\mathrm{X} \mid$ where $\mathrm{X}$ is within an oval ${ }^{27}$.

A specimen from the edge of the blade shows a microstructure of ferrite and pearlite, with a few slag inclusions. The overall carbon content is around $0.3 \% \mathrm{C}$.

Microhardness range 149-179; average $=152 \mathrm{VPH}$.

\section{Helsinki Kansali Museo 1174:2 (Figs. 115-116)}

It has an inscription on one side $+\mathrm{VL} \Gamma \mathrm{P} .$. and on the other side || $\mid \mathrm{X}$ where $\mathrm{X}$ is within a lozenge ${ }^{28}$.

The microstructure shows a mixture of equiaxed ferrite grains and pearlite areas as well as some elongated slag inclusions. The overall carbon content is around $0.3 \% \mathrm{C}$.

Microhardness range 187-261; average $=211 \mathrm{VPH}$.

\section{Chertsey Museum sword (Fig. 117)}

The inscription appears to be $+\mathrm{M}-\mathrm{B}$ E RIT +

$\mathrm{M} F$ might be IVIF and the crosses have flat end-pieces.

The surface hardness was measured and found to vary from 91 to $190 \mathrm{VPH}$ (average = $144 \mathrm{VPH}$ ). Although it was not possible to take a sample for metallography, it seems highly unlikely that this is anything other than a bloomery iron.

\section{Institute of History, Tallinn University K85.121 (Figs. 118-119)}

This was a broken swordblade, only $56 \mathrm{~cm}$ in length, and without any hilt, but with an inscription, which may now be read only as - - B - - - - T or even perhaps

(..) L F (Г) (H) (E) T ...

Anteins ${ }^{29}$, read the inscription of K85:121 as K L IIIH X D (?)

A sample was detached from the broken end, at the edge.

Metallography: the microstructure consists of ferrite and isolated areas of somewhat divorced pearlite. The carbon content is around $0.1 \%$. There are also numerous slag inclusions

\section{Institute of History, Tallinn University AI 2643:108 (Figs. 120-122)}

This was a sword from Randvere, on the island of Saaremaa, which was analysed by Anteins, who sectioned it transversely ${ }^{30}$. He found that the central core was $0.15 \% \mathrm{C}$, and the outer layers were $0.4 \%-0.8 \% \mathrm{C}$. The outer strips appeared to reach to the edges. It will be noted

27 Leppäaho, op. cit.: 42.

28 Ibid.: 42.

29 Anteins, op. cit.: 58.

30 A. K. Anteins, «Pattern-welded objects found in Baltic states». Journal of the Iron \& Steel Institute, 206 (June 1968): 563-571. This is a much shorter (English) version of Anteins (1973). 
that the cutting edges were iron, and the backing strips steel - the opposite of the desirable arrangement. The surface was polished by Anteins, but the inscription was not then described in any detail. In a later publication (1973) he published his reading of this as +VLFBERH+ (without a final T).

The hardness varies from 130-190 VPH in the centre. A section was removed from the broken end for re-examination. The microstructure consists of ferrite and pearlite only, with slag inclusions. One of the outer bands appears to be wider than the other. The cutting edges are formed from the low-carbon band, which does not suggest that it would have been a very successful sword.

Division between high- and low-carbon bands is marked by elongated slag inclusions. The upper surface in this photomicrograph is the outer surface of the sword (scale bar $=100$ microns). A large corrosion crack has opened up.

SUMMARY:

The metallurgical results may be summarised as follows:

Group A: Swords with their maker's name spelt +VLFBERH+T

Out of these 14 swords, nine are made of hypereutectoid steels, and a tenth may also have been. The others are all made of eutectoid steels, which might of course have come from a steel hypereutectoid in other places. So all 14 could have been made from a crucible steel, whatever the source of that might have been.

Group B: Swords with their maker's name spelt the same way, but with the second cross in a different position +VLFBERHT+

Out of these five swords, three were fully hardened and a fourth partly hardened. Three of the hardened 4 have only their edges made of steel, and although it is not possible to know what the bodies of the others were made of, it seems probable that they were all made the same way.

Swords with their maker's name as a variant spelling show more diverse microstructures.

Group C: These 14 are made of medium-carbon steel, at least in their edges.

6 had Steel edges hardened by quenching, including an unsuccessful attempt at quenching

VLFBERN+T

+ VLFBERH $+\perp$

$+\mathrm{VLFBEH}+\mathrm{T}$

$+\mathrm{V} \Gamma\lrcorner$ FBERHTC + and INGEFLRII (sic)

$\mathrm{V}(\mathrm{L}) \ldots(\mathrm{B}) \ldots . . \mathrm{T}$

+ VLFBERH+

A further 8 swords had Steel edges, but were not quenched.

+ VLBERHT + (+ Latin crosses $)$

+ VLFBERHI

+VLFBERHCT

+VLFBERH++

VLFBERHH

$\mathrm{H}\ulcorner\mathrm{XINT}+$ 
+ I I E...

..BRT

Group D: Swords largely made of iron, or low-carbon steel. These 11 swords were of the lowest metallurgical quality, and also generally show the greatest variations in spellings.

$+\mathrm{VL}$ CBERH $+\mathrm{T}$

...F V ...

VLFB ...H..+

$+\mathrm{VI}_{\urcorner} \mathrm{IFR} \mathrm{I}+\perp$

..... R T ...

$\dddot{-1} \mid\left\ulcorner\left.\right|_{T} T^{\lrcorner \perp}+\right.$

+ VLEHBAH LN++

$+\mathrm{VLTP} .$.

$+\mathrm{M} F \mathrm{~B}$ E RIT +

.......L F TH E T ...

+ VLFBERH+

(Group E). OTHER VIKING SWORDS WITH INSCRIPTIONS

E.1. The analysis of a sword found at Donnybrook (County Dublin) and subsequently displayed in Castle Museum, Nottingham (T608) is given in Hall ${ }^{31}$. (Fig. 123).

The inscription appears to be $\mathrm{F} \mathrm{N} \mathrm{H} \mathrm{I}\lrcorner$ I (T). The drawing (by N. Griffiths) is reproduced by courtesy of the Society for Medieval Archaeology.

A sample was taken from the broken end, and analysed in the Ancient Monuments Laboratory, London, for elements by EPMA as well by metallography.

\begin{tabular}{|l|c|c|c|c|c|c|c|}
\hline$\%$ & $\mathrm{C}$ & $\mathrm{Si}$ & $\mathrm{Mn}$ & $\mathrm{S}$ & $\mathrm{P}$ & $\mathrm{Ni}$ & $\mathrm{Al}$ \\
\hline Centre & 0.2 & $*$ & $0.1-1.0$ & 0.01 & 0.02 & n.d & $<0.01$ \\
\hline Edge & $0.3-0.4$ & $*$ & 0.1 & $\operatorname{tr}$ & $\operatorname{tr}$ & $0.2-0.3$ & nd \\
\hline
\end{tabular}

$\operatorname{tr}=$ less than $0.01 \%$

nd $=$ not detected

Silicon was not specifically determined, since analysis would have included slag. The microstructure consisted of ferrite and «pearlitic carbides» in the centre and «tempered martensite» with some ferrite near the edge. The hardness was $250 \mathrm{VPH}$ at the centre and 520-550 VPH at the edge. The photomicrographs published suggest a piled structure, so presumably the higher $\mathrm{C} \%$ of the edges was intentional, to give harder edges on quenching, whatever the precise method of heattreatment employed. The slag inclusions were said to be «mostly alumino-silicates» with only traces of Mn, S, P, and Fe. Most of the manganese seems to have gone into the matrix, surprisingly.

The opportunity was also taken to analyse samples of brass and silver from the upper guard. The brass plate was $90 \% \mathrm{Cu}$ and $10 \% \mathrm{Zn}$, with homogenous distribution of the zinc, and only traces of lead and tin. The «silver» was in fact a eutectic alloy of $72 \% \mathrm{Ag}$ and $28 \%$ $\mathrm{Cu}\left(\mathrm{m} . \mathrm{pt} .780^{\circ} \mathrm{C}\right)$ with traces of $\mathrm{Zn}, \mathrm{Sn}$ and $\mathrm{Pb}$.

31 R. A. Hall, «A Viking-age grave at Donnybrook». Medieval Archaeology, 22 (1978): 64-83. 


\section{E.2. Sword from Olomouc}

This fragment of a late $10^{\text {th }}$ or early $11^{\text {th }}$ century sword was excavated in 1889 and rediscovered in the collections of the Museum of Olomouc (A94696) a few years ago. It comes from the city of Olomouc, and should not be confused with the +VLFBERHT+ sword which was discovered at Nemilany, $5 \mathrm{~km}$ from the centre of Olomouc - published by Selucka et al. (see above). It was possibly associated with the Polish occupation of Moravia in the early $11^{\text {th }}$ century.

It bears an inscription on one side and a pattern-welded panel on the other side. The inscription is made up of letters which, according to Frait ${ }^{32}$, might be read as (V)(B) EH although damage to the fragment makes the $\mathrm{V}$ and $\mathrm{B}$ doubtful.

This sword has been analysed by Hošek ${ }^{33}$, who found that the blade had cutting edges of steel, hardened to $545 \mathrm{VPH}$ while the core was composed of a heterogeneous steel of 197 VPH on one side and the pattern-welded panel on the other side. This panel was made up of high- and low- phosphorus layers, whose hardness reached $259 \mathrm{VPH}$ in the high P\% areas. Fragments of a «silver»inlay on the pommel were also analysed and found to consist of: $\mathrm{Cu}$ $14 \%$, Zn 1\%, Ag 82\%, Sn 1.4\%, Pb 1.6\%.

\section{E.3. Sword from a Private Collection (on loan to the Metropolitan Museum of Art, New York)} (Figs. 124-125)

Possibly $9^{\text {th }}$ century. It has an inscription which might be read as HARTO( ) FER

The microstructure of a sample taken from the edge consists of a mixture of blocky ferrite and areas of untempered martensite. This appears to be a low-C\% steel which has been quenched. The microhardness reaches $296 \mathrm{VPH}$ in places.

The microstructure of a sample taken from near the surface, as well as that of samples from the tang and pommel, consists of ferrite and slag; these parts are made of wrought iron. The blade has apparently been carburised (but only in a very thin layer) and then quenched (but not tempered) in an attempt to harden it.

\section{E.4. Helsinki, Kansali Museo 8911 (Figs. 126-129)}

Possibly $10^{\text {th }}$ century. With an inscription on one side REX and on the other side CONSTANIIENS with the $\mathrm{N}$ s reversed and the middle A and N run together (reading of Leppäaho ${ }^{34}$ ). It might be a debased copy of CONSTANTINUS ${ }^{35}$. A complete section was available from the research initiated by Leppäaho, but never completed.

The microstructure consists of pearlite and ferrite with some slag inclusions. There are also lines of inclusions where the outer pearlitic areas (of around $0.5 \% \mathrm{C}$ ) have been welded to the central, ferritic areas. This sword has been forged from a billet made up of a piece (or several pieces) of iron surrounded by pieces of steel, to give a harder outer part, and harder edges, but it has not been quenched. It seems to be representative of many swords of average quality.

32 R. Frait, Malodohradištní meč z Univerzitní ulice v Olomouci. Zprávy Vlastivědného muzea v Olomouci, 2006: 97-102.

33 J. Hošek, Meč i.č. A94696-Olomouc. Metallographic report No. 11403/07. Archive of Institute of Archaeology CAS, Prague, 2007, v.v.i.

34 J. Leppäaho, Späteisenzeitliche waffen aus Finland. Helsinki, 1964: 38.

35 Oakeshott, op. cit.: 35 , for a similar inscription. 
Electron microanalysis of Helsinki 8911 (whole section). The metal matrix is virtually pure iron (with some $\mathrm{C}$ ). The long inclusions are from the steely layer near the edge. The long inclusions from the boundary between the layers are of iron silicate (with $\mathrm{Mn}, \mathrm{Ca}, \mathrm{Mg}, \mathrm{Al}, \mathrm{K}$ ) and there are some lumpy ones which are the same. Along the forge-welded area there are no traces of other elements, which might have been used as a flux. The lumps along the weld are larger inclusions of silica, and the stringers consist of iron silicate (with $\mathrm{Ca}, \mathrm{Mg}, \mathrm{Al}, \mathrm{K}$ ). The area of lower C\% has blocky, small, inclusions, high in Si (but overall like the others except for lacking Mn). Next to the stringer is a layer of iron oxide.

\section{E.5. Saaremaa Museum K85-123 (Figs. 130-131)}

It has been polished in the past, but only a few letters can be discerned. ....S... A section was removed from the end of the broken blade. Anteins ${ }^{36}$ described it as a letter-like inlay resembling $\mathrm{H} \mathrm{K} \mathrm{I} \Lambda \mathrm{I}$

Metallography. The microstructure consists mostly of pearlite with a lower-C\% band near the surface. There is a sharp division between the two areas. There are long inclusions, apparently from folding during manufacture, as well as a few small elongated inclusions.

\section{OTHER VIKING SWORDS (WITHOUT VISIBLE INSCRIPTIONS)}

\section{E.6. A sword from a Private Collection (Figs. 132-134)}

Perhaps $8^{\text {th }}$ or $9^{\text {th }}$ century; with a silver-inlaid hilt. A specimen was taken from the sword, near the edge. The microstructure consists of fairly uniform fine pearlite, irresolvable in places, with a few small elongated slag inclusions. There are also several large, lumpy, slag inclusions. Around the edges, in the vicinity of areas of corrosion products, there are layers containing ferritic grains as well as the pearlite. The carbon content of the edge is around $0.7-0.8 \%$.

The microhardness of the edge ranges from 311 to 357 ; average $=330 \mathrm{VPH}$, except away from the edge it ranges from 159-215 VPH.

Electron microanalysis. The metal matrix is virtually pure iron. Some elongated inclusions of iron silicate (with $\mathrm{Mg}, \mathrm{K}$ ) a typical bloomery slag. Another inclusion is high in $\mathrm{Si}$ (perhaps from the furnace lining?).

\section{E.7. A sword from a Private Collection (Figs. 135-137)}

Possibly $10^{\text {th }}$ century. The microstructure consists of a mixture of areas of pearlite, lamellar in places, and irresolvable in others, with carbide particles arranged in a network, areas of irresolvable material with a generally acicular appearance, and a few slag inclusions. No separate areas of ferrite seem to be visible.

This microstructure is that of a low/medium-carbon steel which has undergone some form of accelerated cooling, resulting in a mixture of pearlite and (possibly) bainite, which has then subsequently been reheated to temper it.

Microhardness range 308-345; average $=324 \mathrm{VPH}$

36 Op. cit.: 51. 


\section{CONCLUSIONS}

The original maker of the «Ulfberht» swords was evidently a craftsman (or perhaps a craftsman/merchant) who had access to a source of high-carbon steel. This may well have been ingots of crucible steel imported from the Middle East via the River Volga. In which case, his location was probably in the Baltic area, where this trade route terminated, and where most of these swords have been found (see map).

Such a high-carbon steel would have needed to have been forged, counter-intuitively, at a lower temperature than customary. If forged at the correct temperature and for the correct time, the swords produced would have been both hard and tough, and would have been highly valued. So it is not surprising that many other swordsmiths tried to copy these swords, and also copy their maker's inscription. One workshop, who made their swords with hardened steel edges, copied the spelling exactly, except for placing the terminal + in the wrong place. Other workshops, made swords of differing quality, and differing accuracy of spelling.

The presence of graphite (as well as cementite) in the microstructure of sword \# A.4 is presumably a relic from the manufacturing process, which involved heating cast iron with bloomery iron in a crucible, as described by al-Biruni (973-1048) who describes the melting together of «soft iron» \& «hard iron» (presumably cast iron) in covered crucibles for a matter of days. Eventually enough carbon would have been absorbed for the alloy to melt, and the broken crucible would yield a cake of cast steel, a convenient size for making a sword blade. The product was made around Herat and exported via North India to Persia \& other Muslim lands. The Persians traded in crucible steel ${ }^{37}$, but was any of this exported to Europe? This seems to be the first evidence that this might have been the case. Indeed, there was a wellestablished trade route from the Baltic to Persia via the Volga, exploited by the Vikings in the $9^{\text {th }}-10^{\text {th }}$ centuries, during the period of their manufacture. So there are said to be more Samanid (815-1005) silver coins from their Afghan mines in Sweden than there are in Persia. After the fall of the Samanids, and the rise of the various Russian principalities, the use of this trade route by the Vikings declined ${ }^{38}$. It is notable that, at this time, the manufacture of these «Ulfberht» swords apparently ceases, presumably because the raw material is no longer available.

\section{APPENDIX 1}

Analyses of some samples of hypereutectoid steels were undertaken at the National Physical Laboratory, Teddington, by wavelength-dispersive X-ray spectrometry (WDX). The results are a series of point analyses, and if the beam is centred upon a dendrite of cementite, for example, then the result would not be representative of the structure as a whole. However, the average of a series of such point analyses may well be useful, and so they are quoted here.

Oslo 4690: min.0.586; max.2.326; average (30) 1.546\%C. But if the $\mathrm{Fe}_{3} \mathrm{C}$ dendrites are avoided altogether, then

Average $(15)=1.417 \%$ C. $(\sigma 0.267)$.

37 J. Lang, P. T. Craddock and St. J. Simpson, «New evidence for early crucible steel». Historical Metallurgy, 32 (1998): 7-14. and also P. Craddock and J. Lang, Mining \& Metal production through the ages. London, 2003: 231-257.

38 M. Mitchiner, «Evidence for Viking-Islamic trade provided by Samanid silver coinage». East and West, 37 (Rome, 1987): 139-150. 
Bergen 3149: min. 1.085; max. 6.185; average (22) 2.705. But if the $\mathrm{Fe}_{3} \mathrm{C}$ dendrites are avoided altogether, then average $(9)=1.722 \%$ C. $(\sigma 0.510)$.

Bergen 3149 edge: min. 0.972; max. 2.094; average $(9)=1.608 \%$ C. $(\sigma 0.471)$

Bergen 1483: min. 1.215; max. 2.693; avoiding dendrites 1.536

Average $(6)=1.344 \%$ C. $(\sigma 0.131)$

Bergen 882 : min. 1.719; max. 8.961; avoiding primary graphite, average $(5)=2.724 \%$ C. $\sigma 1.071$

Bergen 1622 edge: $\min .1 .223$; $\max .2 .262$; average $(14)=1.678 \%$ C. $\sigma 0.342$

Helsinki 91643: $\min$. 1.038; $\max .1 .610$; average $(10)=1.241 \%$ C. $\sigma 0.184$.

Bergen 1069: min.0.904; $\max .1 .767$; average $(10)=1.252 \%(0.263)$

\section{EDX inclusion analyses done at NPL:}

Bergen 1165 (average of 7 readings)

\begin{tabular}{l|ccccccccccc}
\hline Spectrum & $\mathrm{C}$ & $\mathrm{O}$ & $\mathrm{Na}$ & $\mathrm{Mg}$ & $\mathrm{Al}$ & $\mathrm{Si}$ & $\mathrm{K}$ & $\mathrm{Ca}$ & $\mathrm{Mn}$ & $\mathrm{Fe}$ & Total \\
Mean & 24.99 & 32.80 & 0.25 & 0.27 & 1.30 & 8.99 & 0.53 & 1.27 & 0.07 & 29.52 & 100.00 \\
\hline
\end{tabular}

Bergen 1069 (average of 3 readings)

\begin{tabular}{l|ccccccccccc}
\hline Spectrum & $\mathrm{C}$ & $\mathrm{O}$ & $\mathrm{Na}$ & $\mathrm{Mg}$ & $\mathrm{Al}$ & $\mathrm{Si}$ & $\mathrm{K}$ & $\mathrm{Ca}$ & $\mathrm{Mn}$ & $\mathrm{Fe}$ & Total \\
Mean & 2.37 & 53.60 & 0.92 & 1.10 & 6.04 & 28.45 & 2.69 & 3.05 & 0.39 & 1.39 & 100.00 \\
\hline
\end{tabular}

And another (average of 6 readings)

\begin{tabular}{l|ccccccccccc}
\hline Spectrum & $\mathrm{C}$ & $\mathrm{O}$ & $\mathrm{Na}$ & $\mathrm{Mg}$ & $\mathrm{Al}$ & $\mathrm{Si}$ & $\mathrm{K}$ & $\mathrm{Ca}$ & $\mathrm{Mn}$ & $\mathrm{Fe}$ & Total \\
Mean & 39.40 & 4.98 & 0.01 & 0.01 & 0.05 & 16.89 & 0.00 & 0.02 & 0.02 & 38.61 & 100.00 \\
\hline
\end{tabular}

Two of these inclusions are basically iron silicates, which is what one would have expected from bloomery iron. This starting material, however, was heated for a considerable time with carbonaceous material, so that iron silicate or oxide would have been steadily reduced to iron, and thus removed from the slag, leaving other inclusions high in silica.

$$
\mathrm{Fe}_{2} \mathrm{SiO}_{4}+2 \mathrm{C}=2 \mathrm{Fe}+\mathrm{SiO}_{2}+2 \mathrm{CO}
$$

The total volume of inclusions would have been greatly reduced, even if the contents of the crucibles were not completely melted. The microstructures of these swords suggest that this was sometimes the case. An imperfectly homogenised crucible steel might well have been one stage on the route to producing a homogeneous cast steel, and eventually a very slowly cooled cast steel (wootz).

\section{APPENDIX 2}

The results of Electron microanalysis on selected swords are given here:

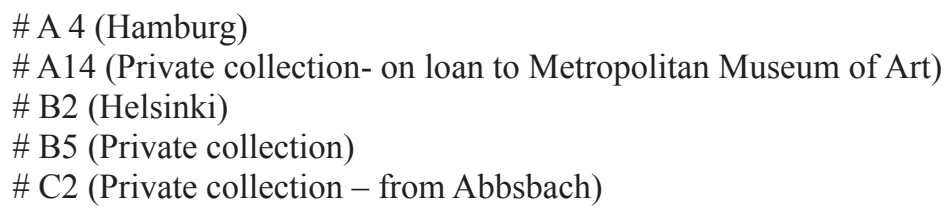


\# C3 (Nürnberg)

\# C6 (Helsinki)

\# D2 (Bergen)

Electron microanalysis was carried out in the Department of Materials Science \& Metallurgy, Cambridge University, with a CamScan MX2600, by Dr. David Nicol.

Metallography and hardness determinations were all carried out by the author. Unless otherwise stated, microhardnesses (Vickers, $100 \mathrm{~g}$ ) were determined from an average of 10 readings.

Some surface hardness measurements were also taken with a Branson-Krautkramer Sonodur, calibrated to read in Vickers Pyramid Hardness (VPH) the units of which are $\mathrm{kg} . \mathrm{mm}^{-2}$.

Publications are in London, unless stated otherwise.

\section{ACKNOWLEDGEMENTS}

I would like to thank those enlightened curators who helped me with this study (in alphabetical place order):

Dr. Birgid Kaland (Bergen Historical Museum), Dr. Ralf Wiechmann (Museum for Hamburg History), Dr. Leena Tomantera (Kansali Museo, Helsinki), Dr. Külli Rikas (Kuressaare Museum), Dr. Tobias Springer (Germanic National Museum, Nürnberg), Prof. Heid Gjøstein Resi, (Museum of Cultural Heritage, Oslo), Dr Arthur MacGregor (Ashmolean Museum, Oxford) and Dr. Michael O'Hanlon (Pitt-Rivers Museum, Oxford), Dr. Rutt Ojasalu (Rakvere Museum), Dr. Barbara Grotkamp (Klingenmuseum, Solingen), Prof. Volker Himmelein (Württemberg Landesmuseum, Stuttgart), Dr. Ulle Tamla, (Institute of History, Tallinn University), Jaak Mäll (Estonian History Museum, Tallinn) Prof. Erik Szameit (University of Vienna) Dr. Christian Beaufort-Spontin (Hofjagd- und Rüstkammer, Vienna) and Dr. Robin Hanley and Dr. Robert Bell (Fenland Museum, Wisbech).

The owners of those swords in private collections cannot be publicly named, although they can be thanked, as they have also played an important part in this study.

I would also like to thank Dr. Dipak Gohil of the National Physical Laboratory, Teddington, and Dr. David Nicol of Cambridge University, for their help with electron microanalyses. Dr. Jiři Hošek (Archaeological Institute, Prague) has kindly shared the results of his analyses of Czech swords with me.

The Society of Antiquaries of London has generously supported the author's travels to Scandinavia.

\section{ADDENDUM}

A sword from the Statens Historiska Museum Stockholm has been studied. The inlaid inscription is not very clear from the accompanying drawing but seems to be HP B E P H T which way well have been a form of VL F B E R T H. The inventory number is SHM 907 and it came from Alands. Hogran parish, Gotland.

The microestructure is described but not illustrated. It was made up of several layers, with an iron $(0,1 \% \mathrm{C})$ layer in the centre, and steel $(0,4 \%-0,8 \% \mathrm{C})$ layers on the outsides. The steel had not been hardened. It would therefore seem to belong to group C (unhardened).

«Metallografisk analys av inlaggingar i vikingatida svardsklinga» Tornblom, M. Fornvannen 76 (1981) 24-5. 


\section{FIGURES}

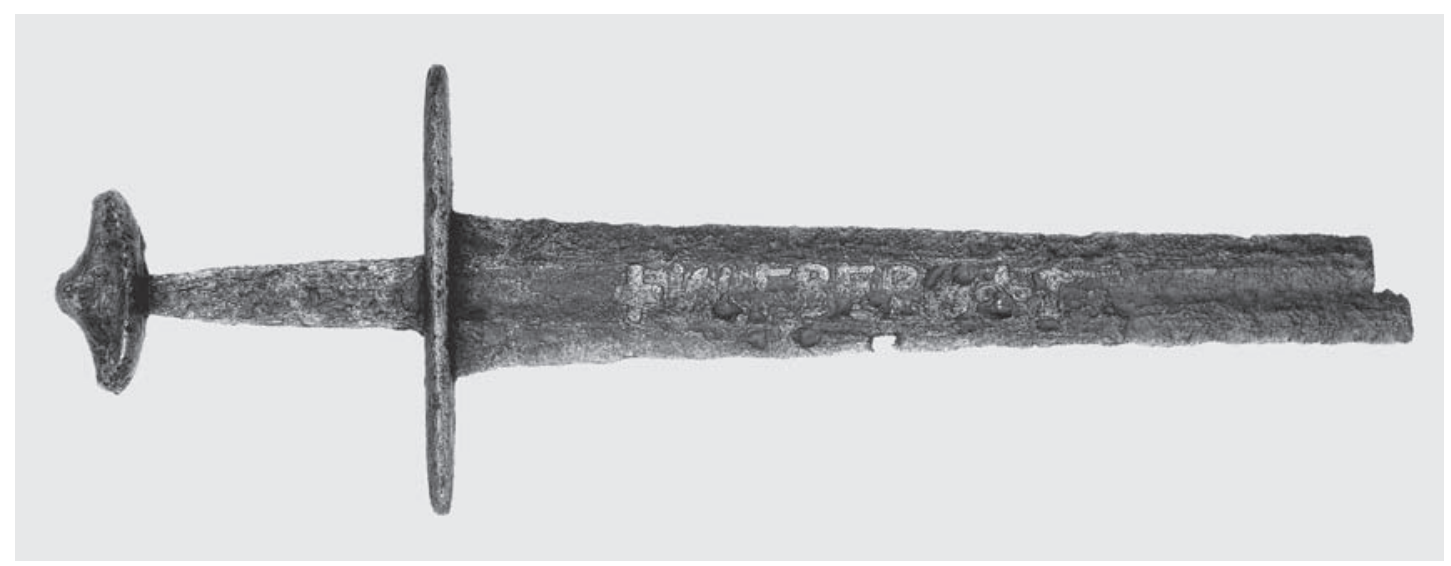

Figure 1. Sword \# A2 from Stuttgart.

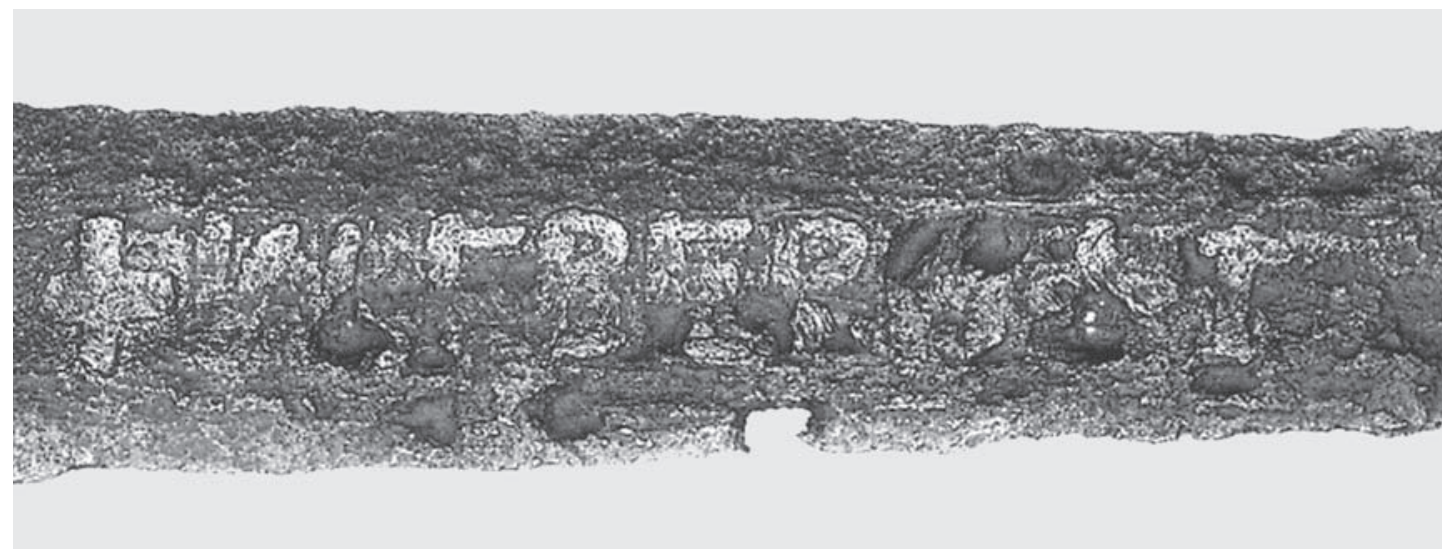

Figure 2. Inscription on \# A2.

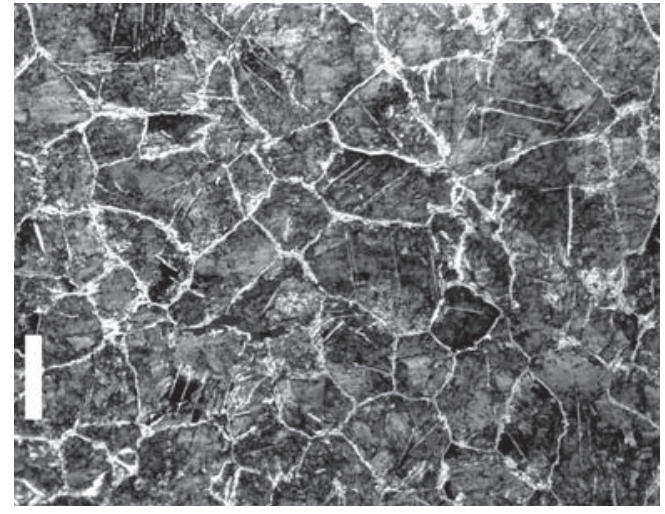

Figure 3. Microstructure of \# A2: pearlite and cementite (scale bar 50 microns).

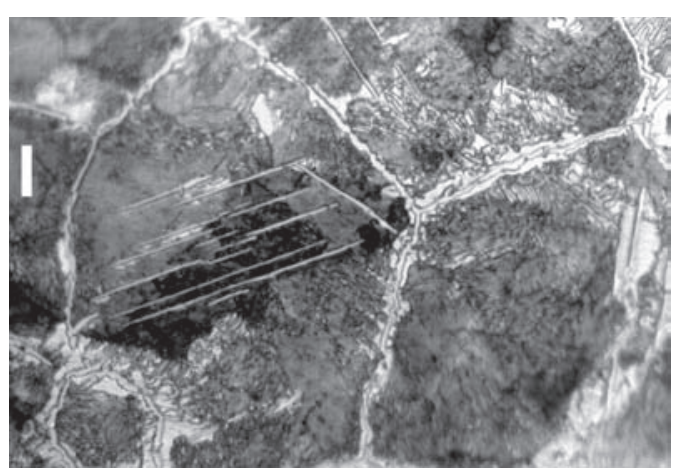

Figure 4. Microstructure of \# A2: pearlite areas and cementite as network and as needles (scale bar 10 microns). 


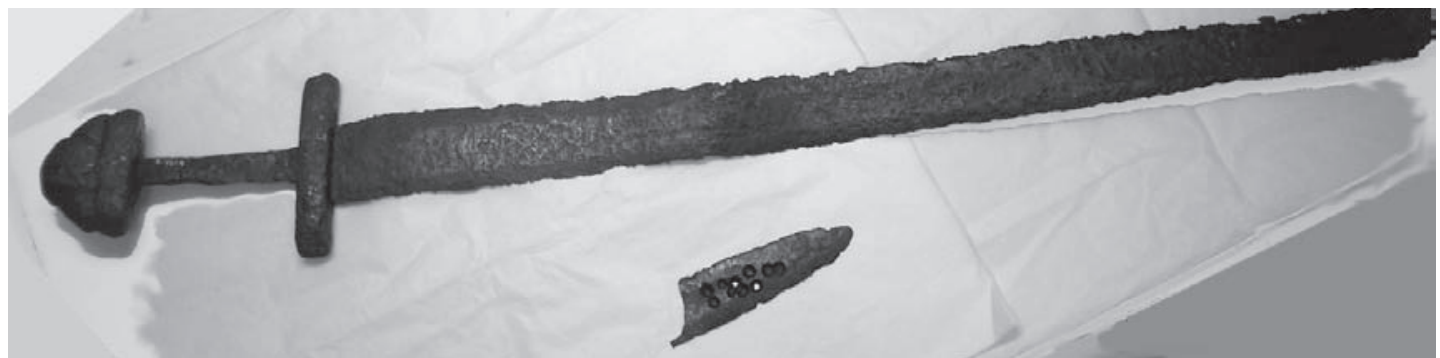

Figure 5. Sword \# A3: the detached end with earlier sample drillings may be observed

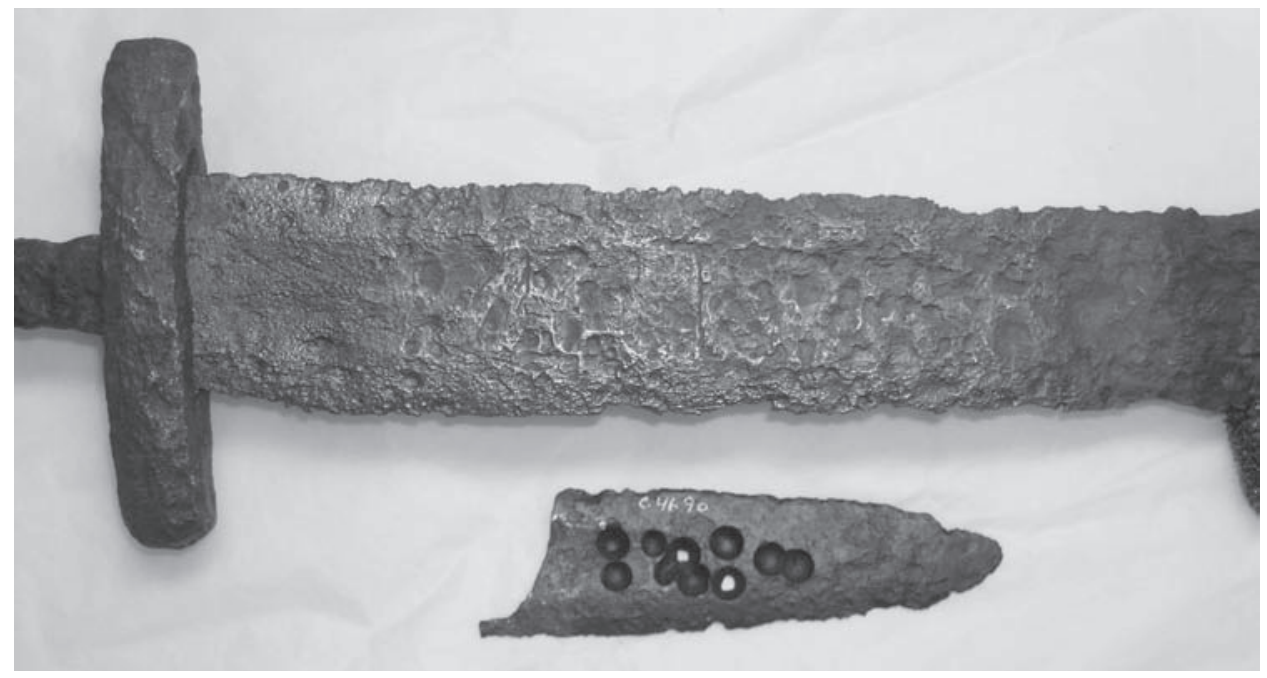

Figure 6. Sword \# A3: remains of the inscription.

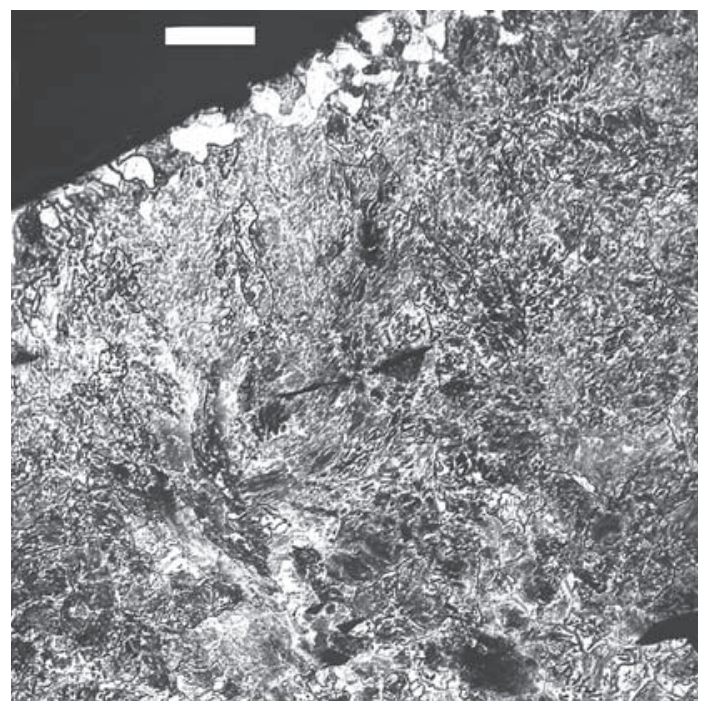

Figure 7. Microstructure of sword \#A3: note ferrite grains near surface. (scale bar $=50$ microns).

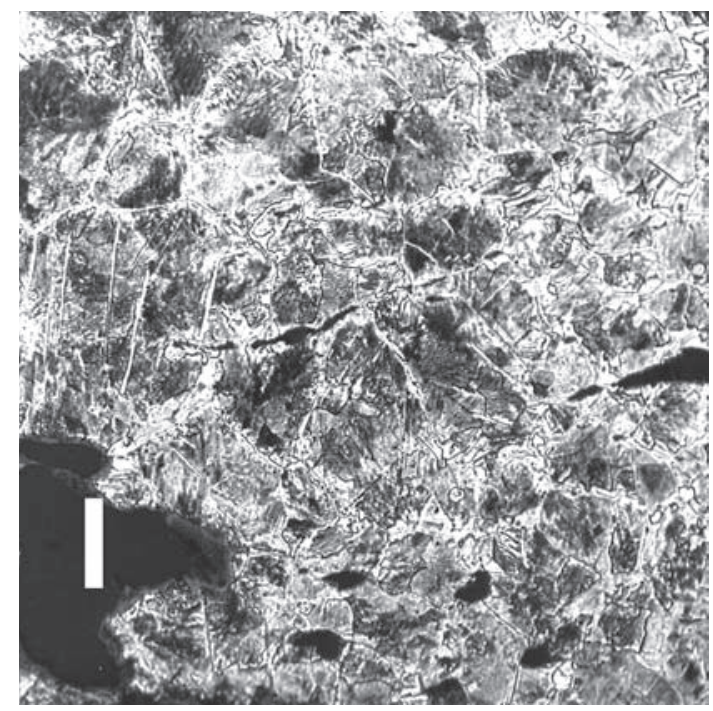

Figure 8. Microstructure of sword \# A3 interior: pearlite and cementite (scale bar $=50$ microns). 


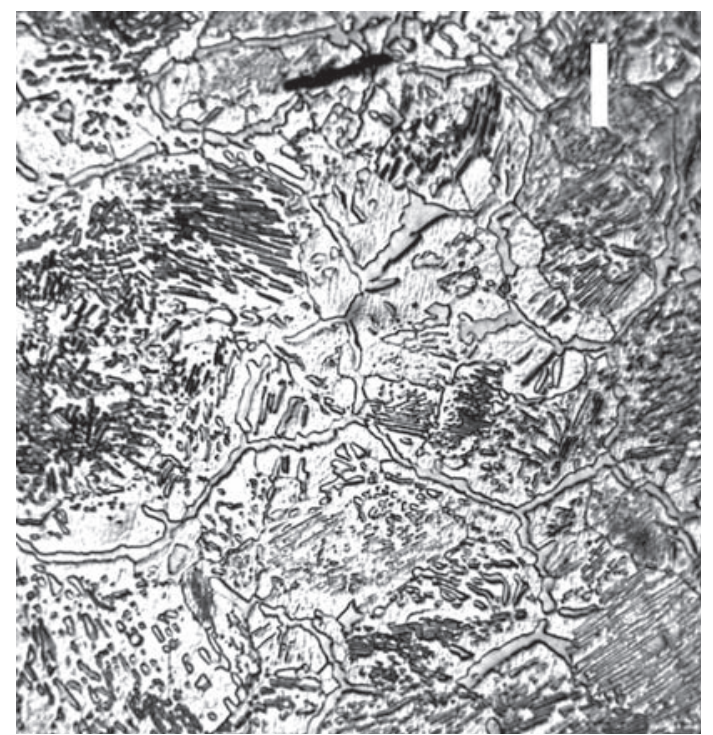

Figure 9. Microstructure of sword \# A3 interior: pearlite and cementite (scale bar $=10$ microns).

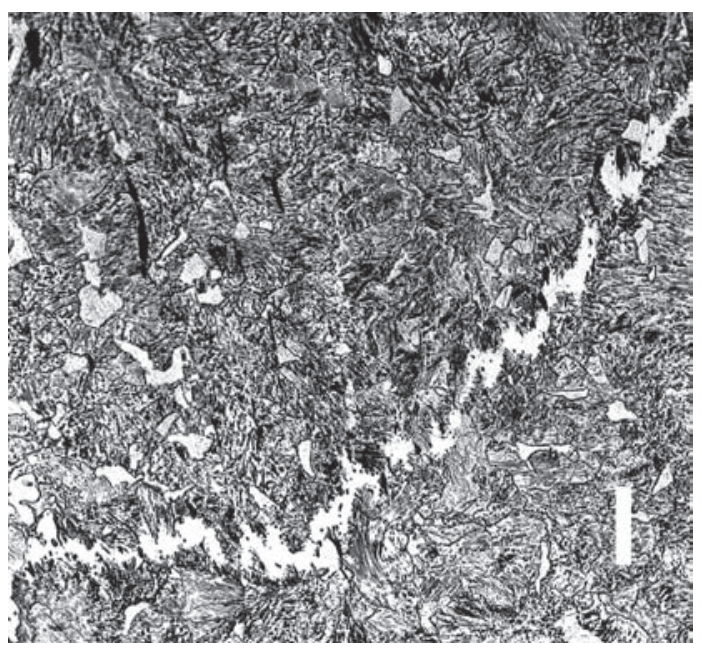

Figure 11. Microstructure of sword \# A3 interior: pearlite and ferrite showing outline of fold from forging also some small elongated slag inclusions (scale bar $=50$ microns).

Gladius, XXIX (2009), pp. 121-184. ISSN: 0436-029X

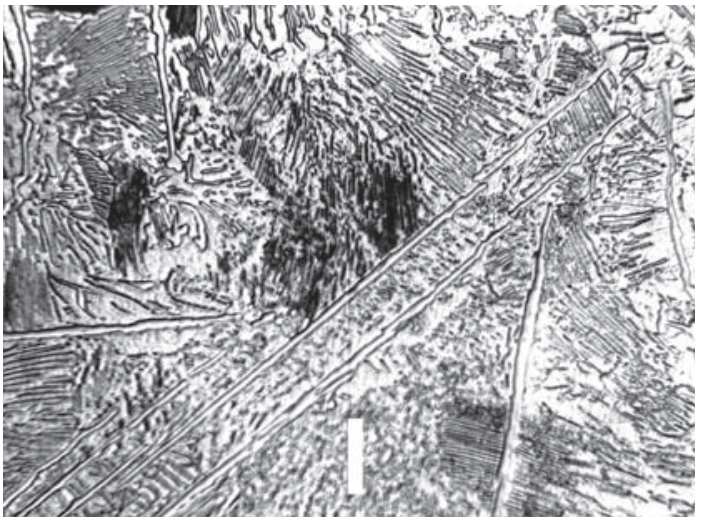

Figure 10. Microstructure of sword \# A3 interior: pearlite and cementite needles (scale bar $=10 \mathrm{mi}$ crons). 


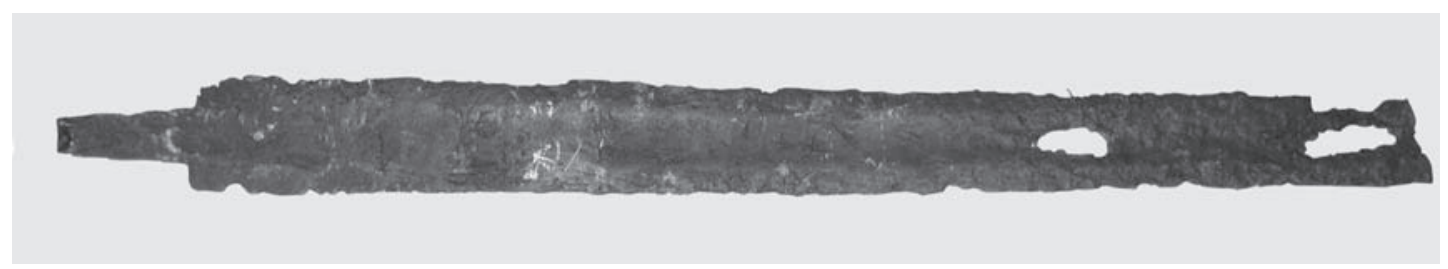

Figure 12. Sword \# A4 from Bergen.

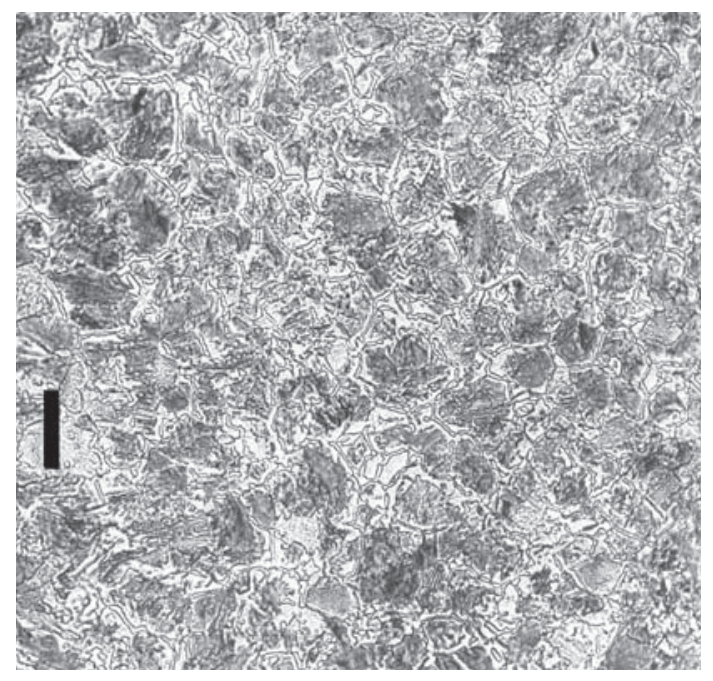

Figure 13. Microstructure of \# A4 body: pearlite and cementite (scale bar 50 microns).

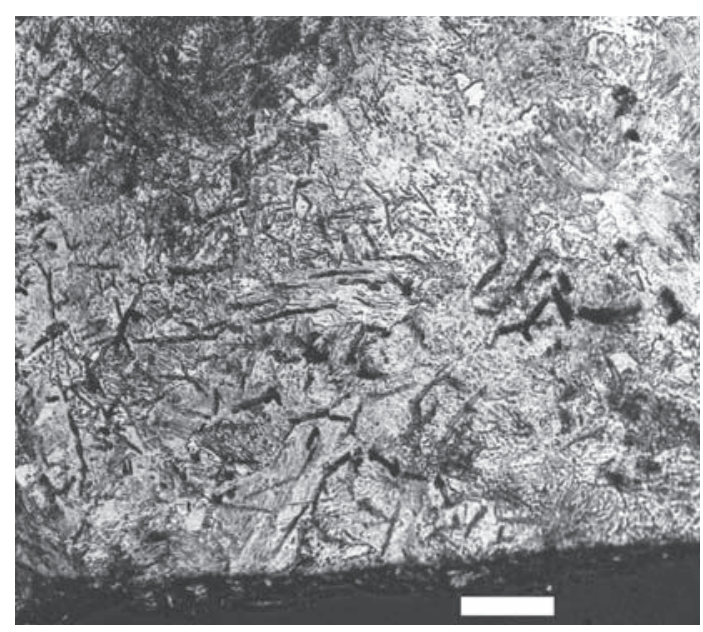

Figure 15. Microstructure of \# A4 edge: pearlite and graphite (scale bar 50 microns).

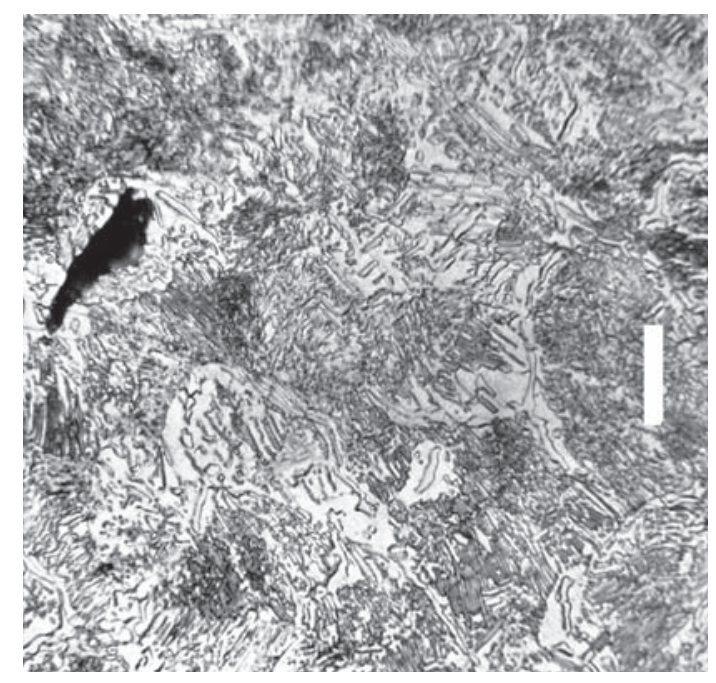

Figure 14. Microstructure of \# A4 body: pearlite and cementite (scale bar 10 microns).

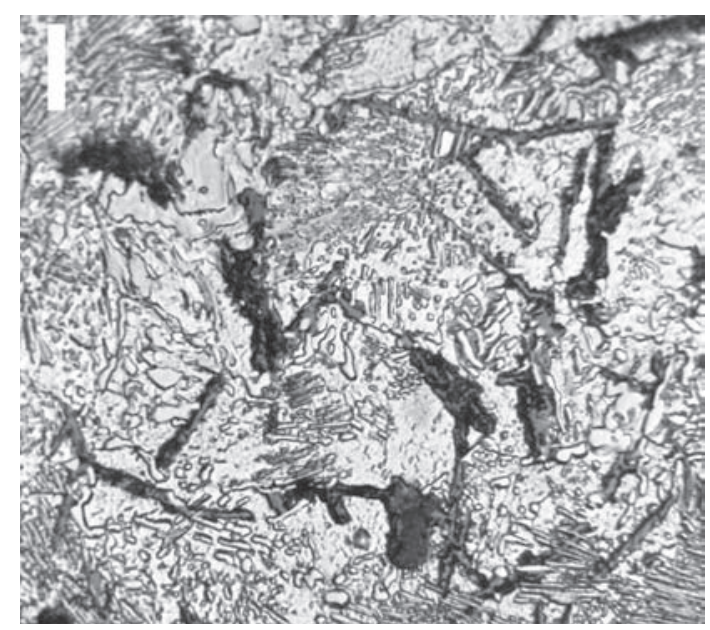

Figure 16. Microstructure of \# A4 edge: pearlite and graphite (scale bar 10 microns). 


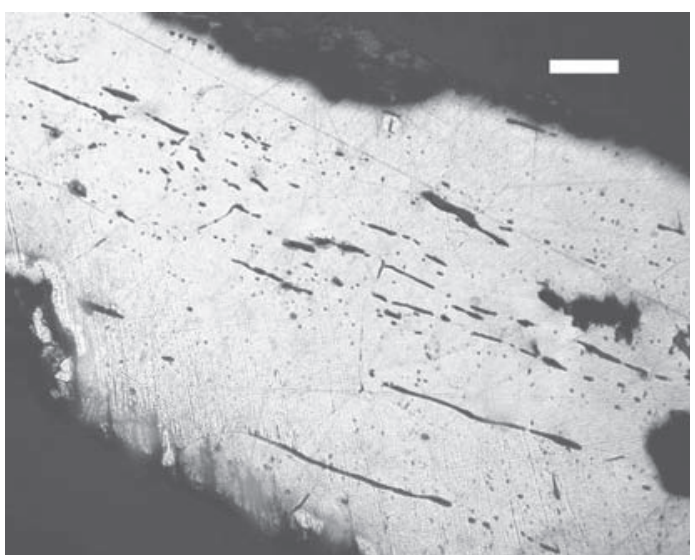

Figure 17. Microstructure of \# A4 inlay: ferrite and slag (scale bar 100 microns).

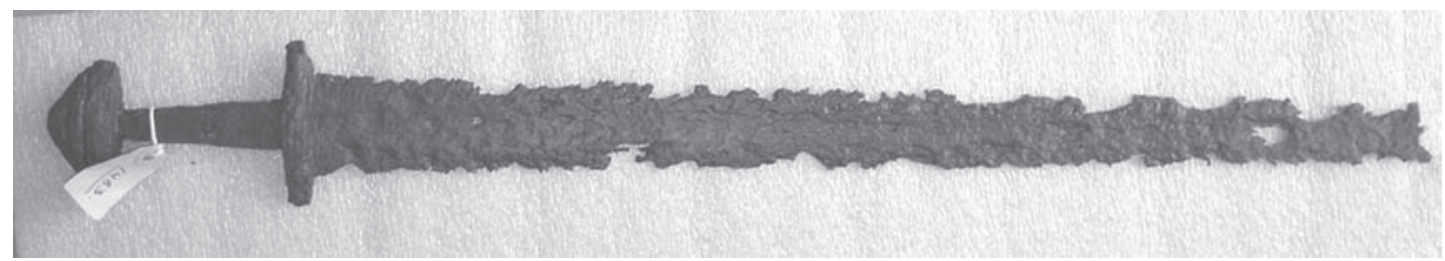

Figure 18. Sword \# A5 from Bergen.

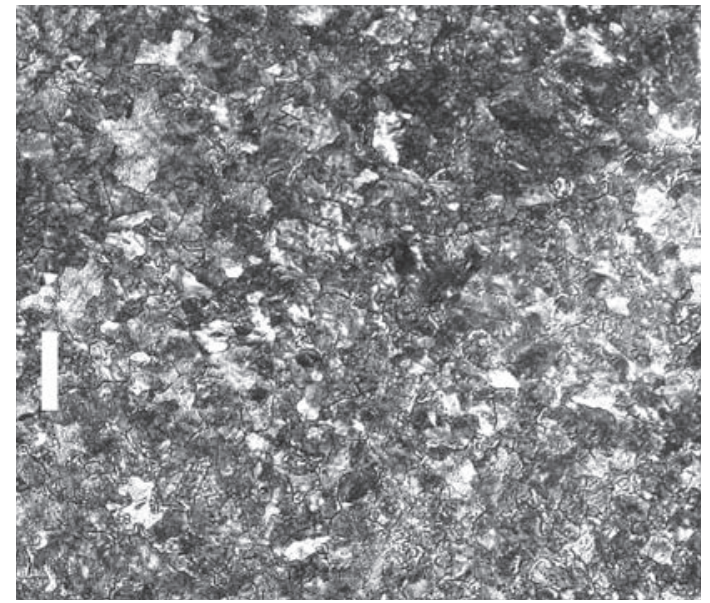

Figure 19. Microstructure of sword \# A5 : pearlite and cementite (scale bar $=50$ microns).

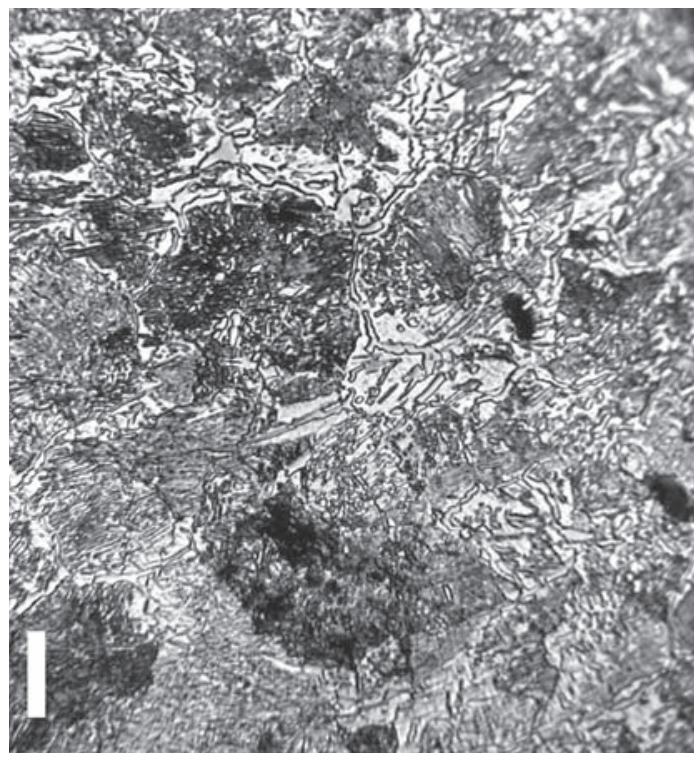

Figure 20. Microstructure of sword \# A5 : pearlite and cementite (scale bar $=10$ microns). 


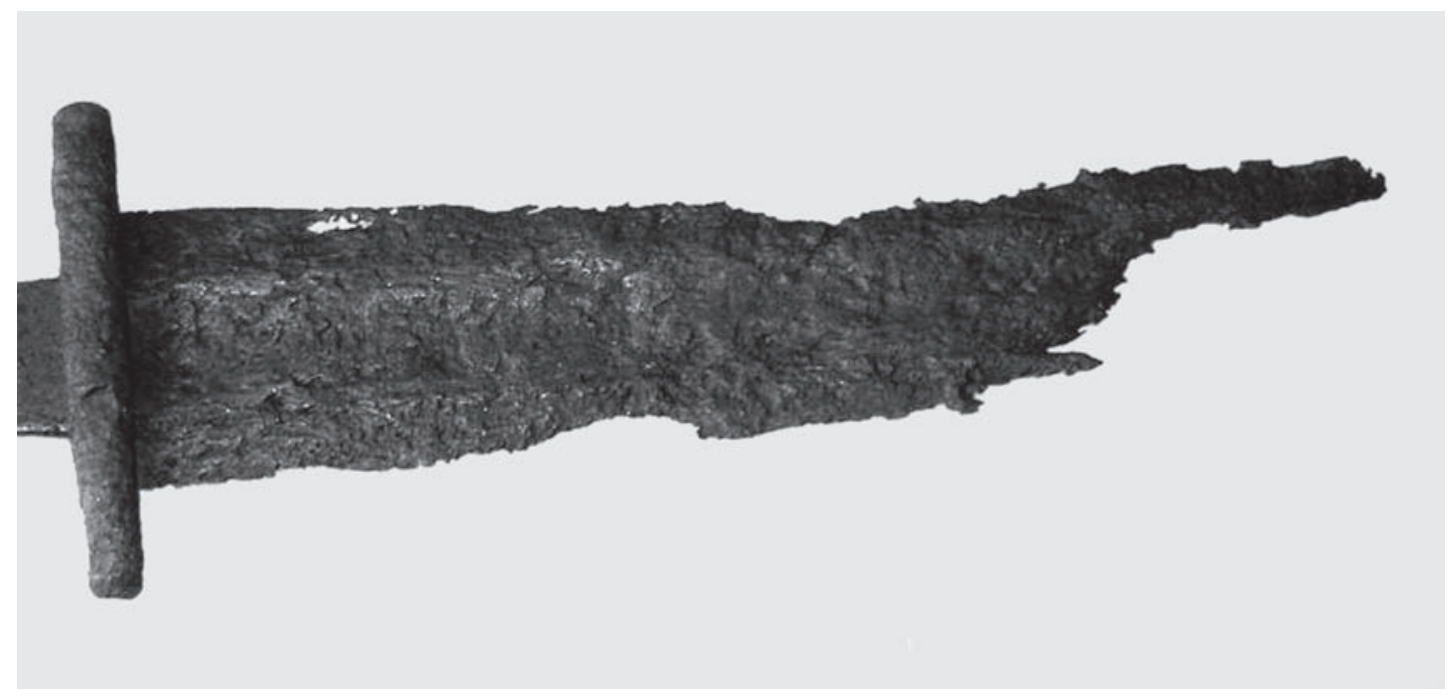

Figure 21. Sword \# A6 from Bergen.

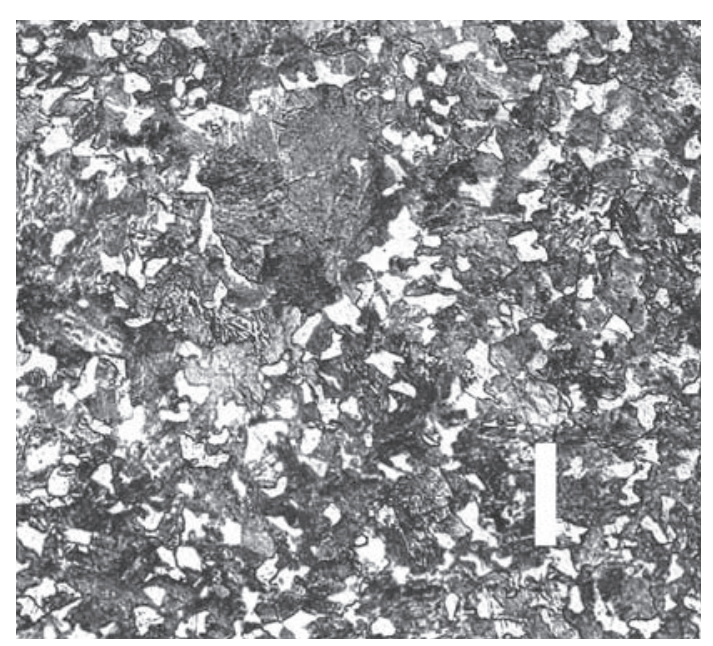

Figure 22. Microstructure of sword \# A6 edge: pearlite and ferrite (scale bar $=50$ microns).

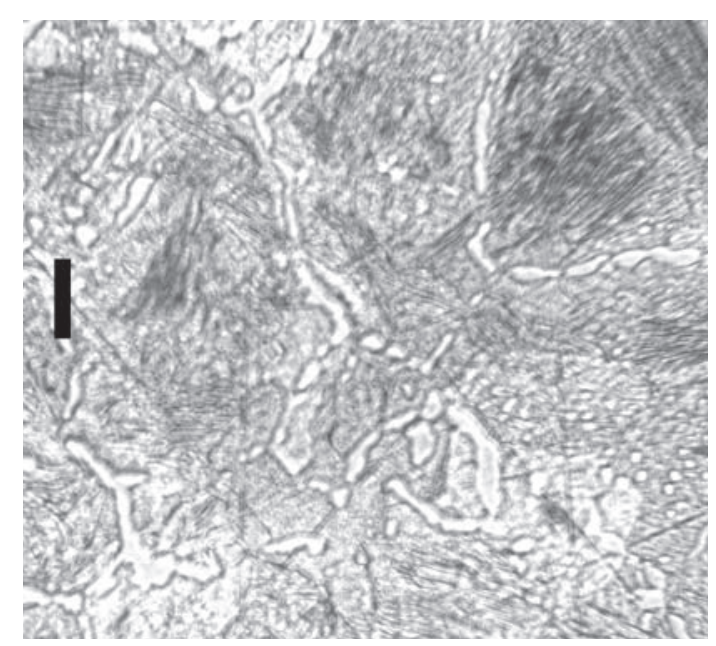

Figure 23. Microstructure of sword \# A6 body: pearlite and cementite (scale bar $=10$ microns). 


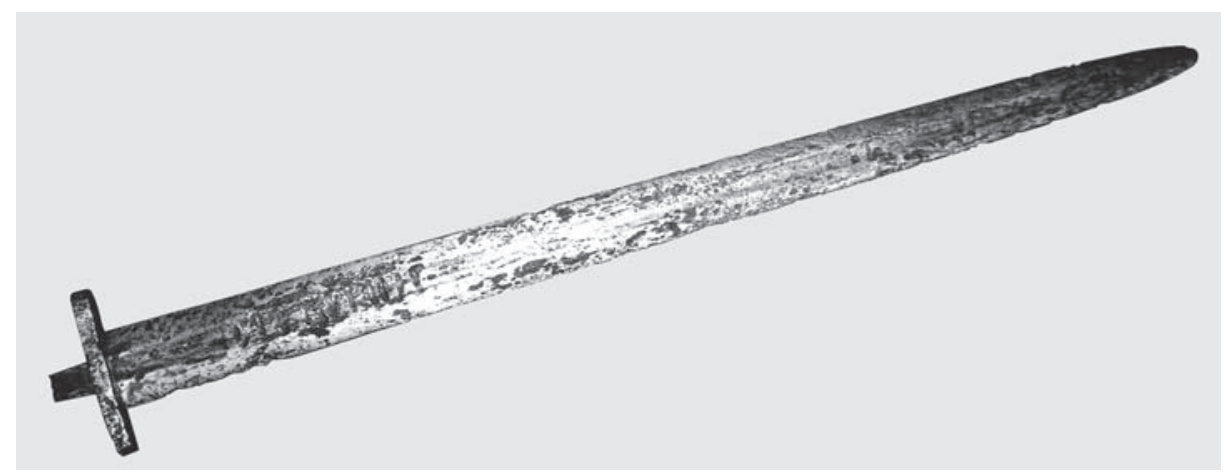

Figure 24. Sword \# A7 from Hamburg.

Figure 25. Microstructure of \# A7: fine pearlite, cementite and very little slag (scale bar 10 microns).
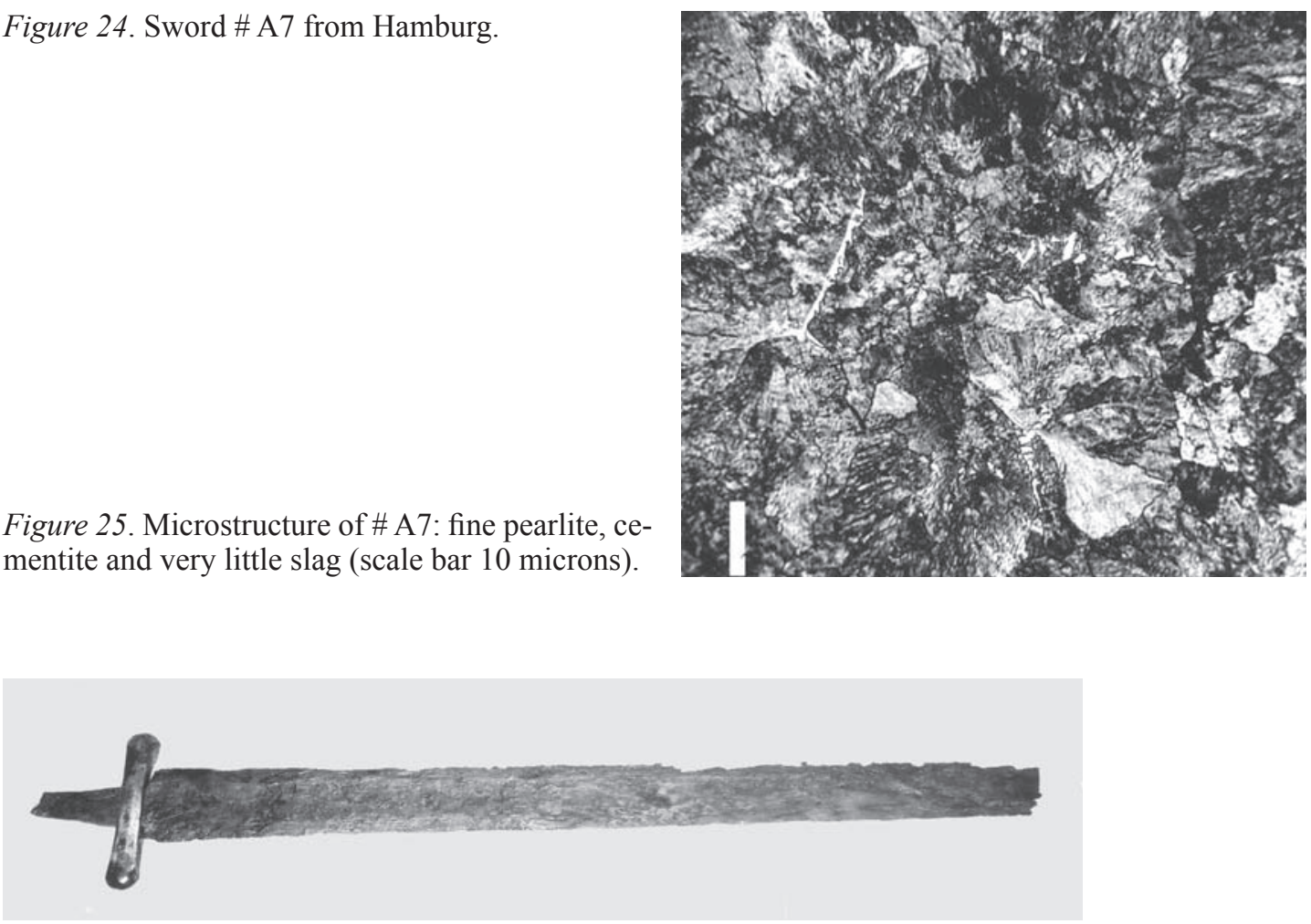

Figure 26. Sword \# A8 from Solingen.

Figure 27. Microstructure of \# A8: pearlite areas with network of carbide particles (scale bar $50 \mathrm{mi}$ crons).

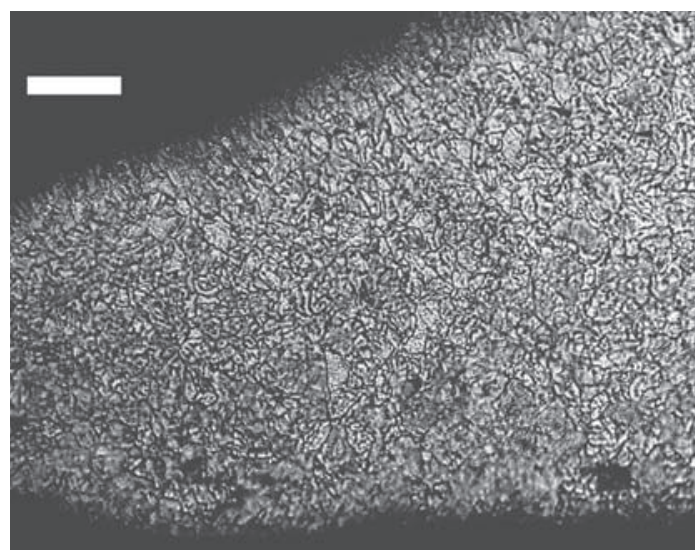




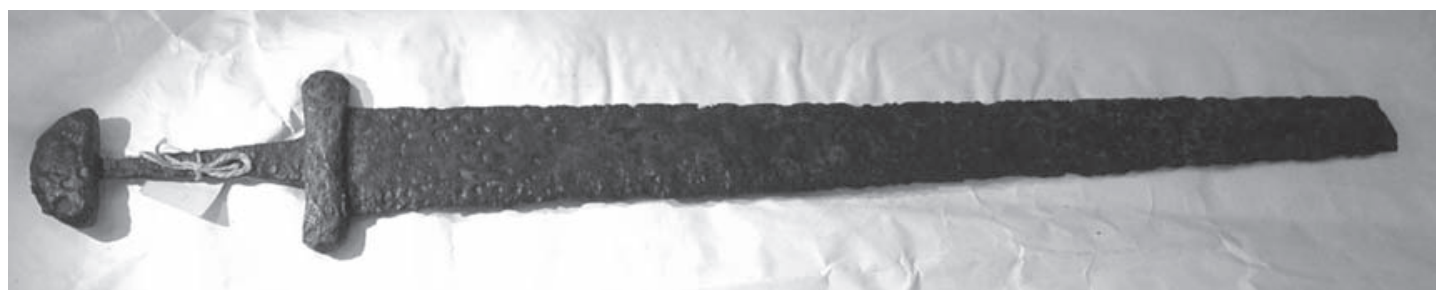

Figure 28. Sword \# A9 from Helsinki.

Figure 29. Microstructure of sword \# A9: very fine (almost irresolvable) pearlite.

(scale bar $=50$ microns).
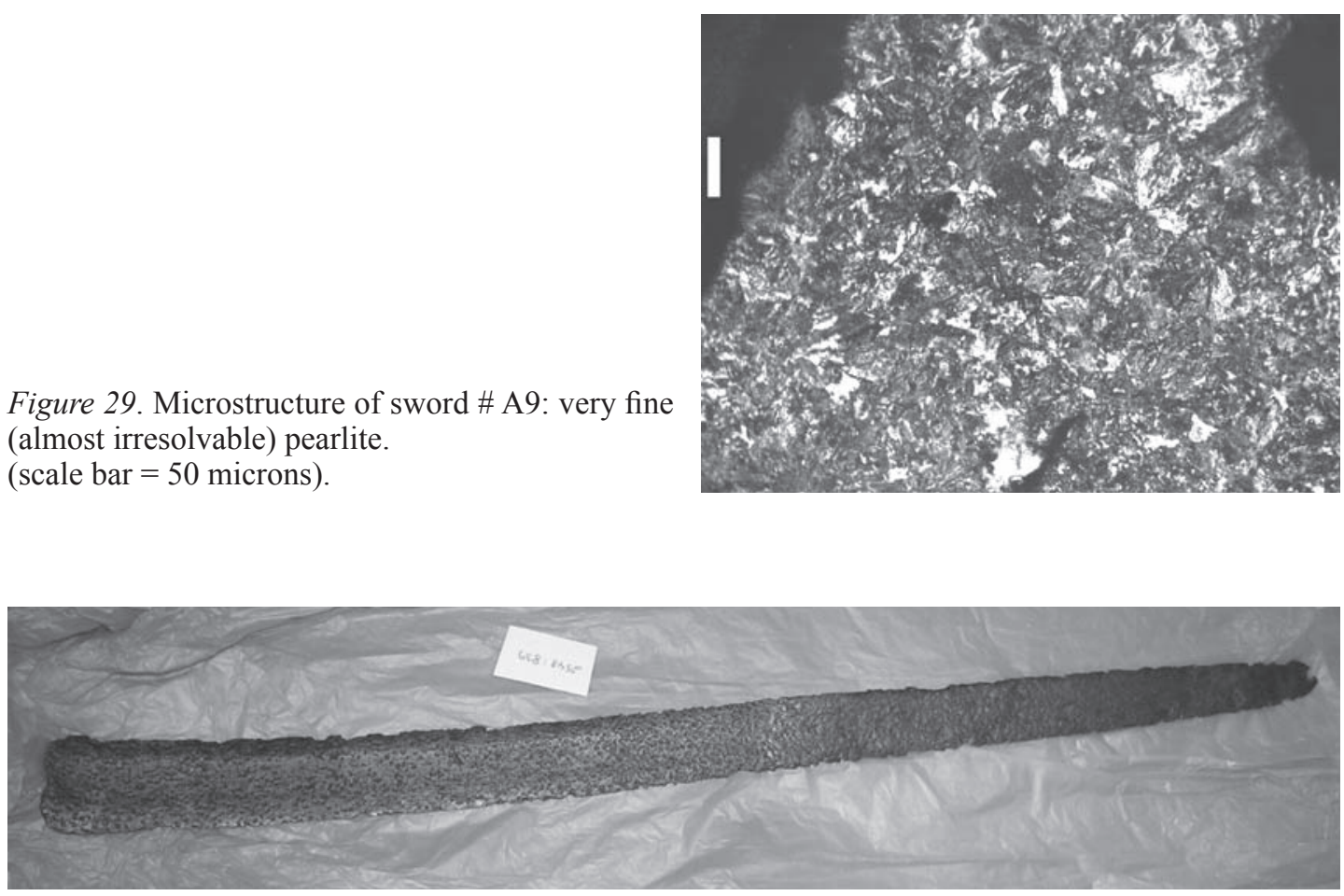

Figure 30. Sword \# A10 from Helsinki.

Figure 31. Microstructure of \# A10: pearlite with varying amounts of ferrite, and slag (scale bar $=50$ microns).

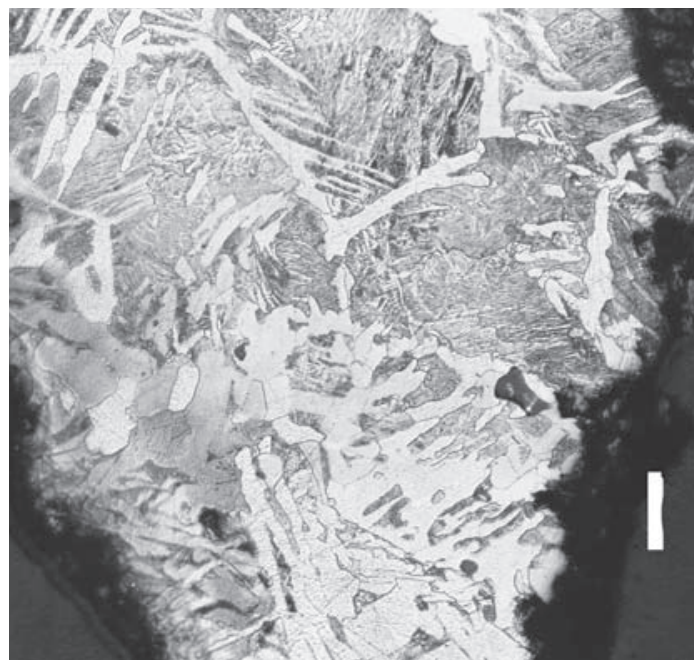




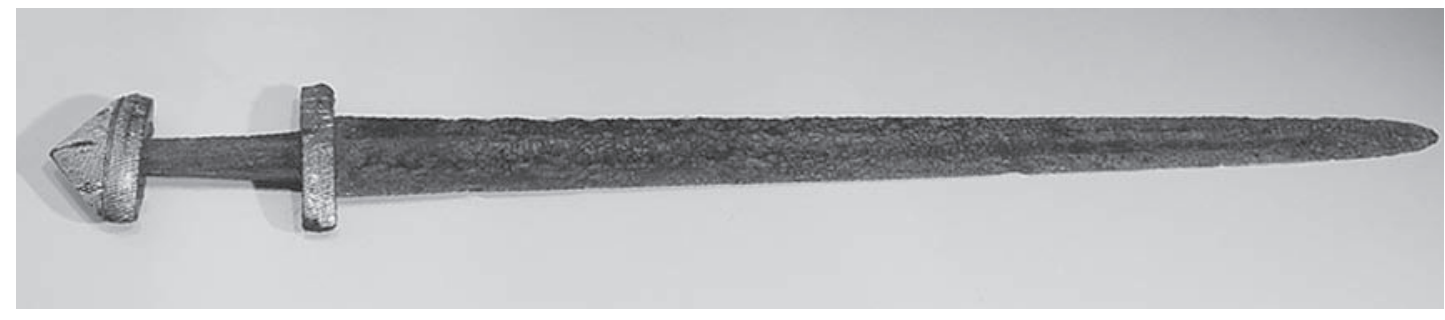

Figure 32. Sword \# A11 on exhibition at the Metropolitan Museum of Art, New York (L.2006.57).

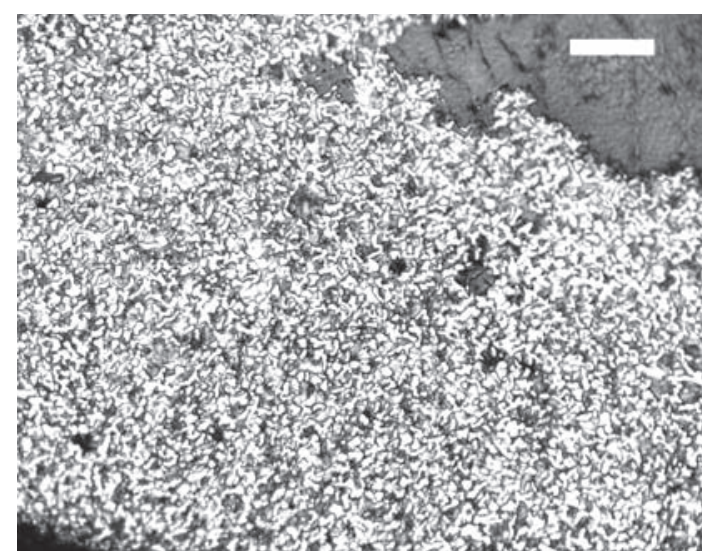

Figure 33. Microstructure of \# A11: pearlite and ferrite (scale bar $=50$ microns).

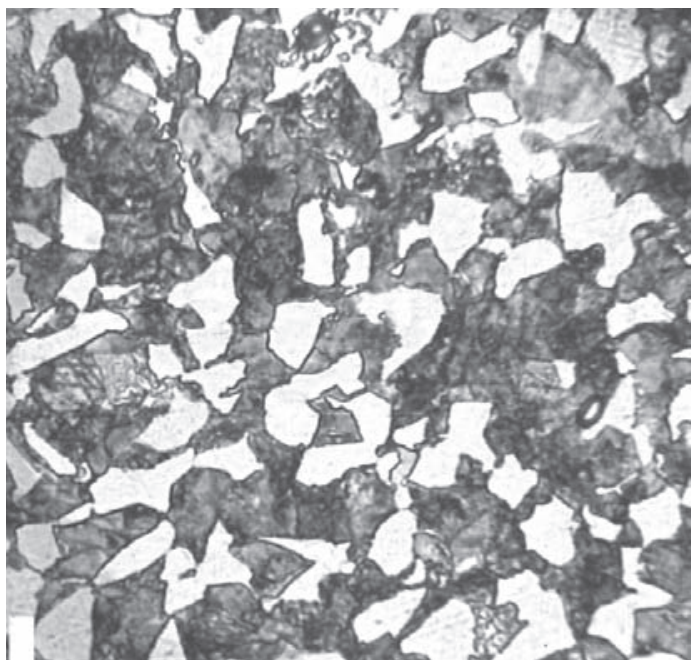

Figure 34. Microstructure of \# A11: pearlite and ferrite (scale bar $=10$ microns). 


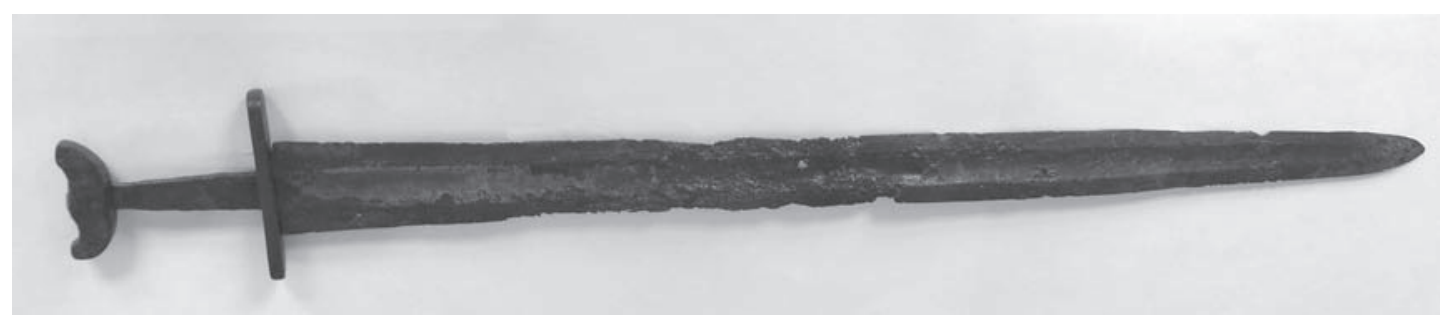

Figure 35. Sword \# A12 from Rakvere.

Figure 36. Microstructure of \# A12 : pearlite and some small, elongated, slag inclusions (scale bar $=50$ microns).
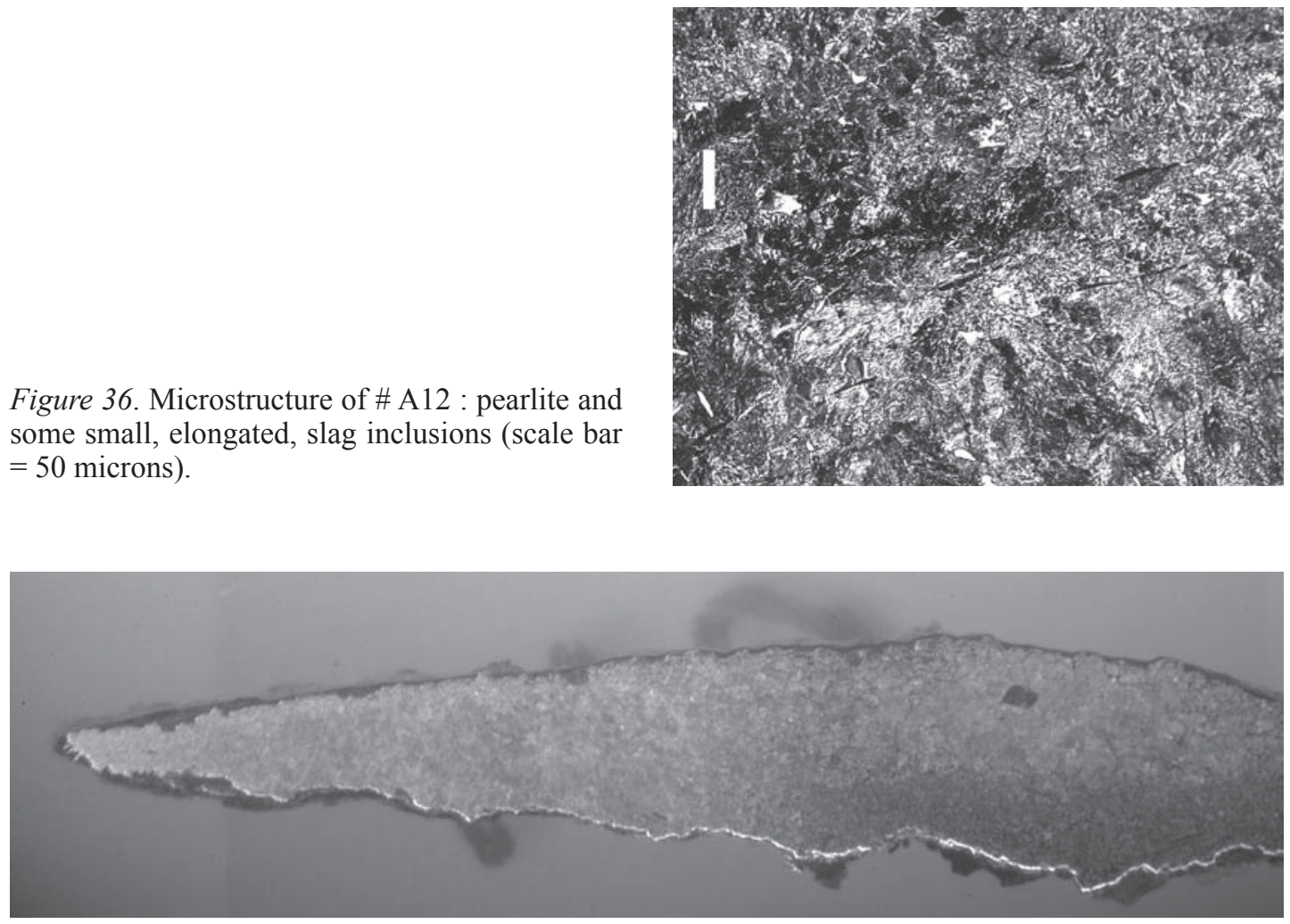

Figure 37. Section of half $(15 \mathrm{~mm})$ the blade width.

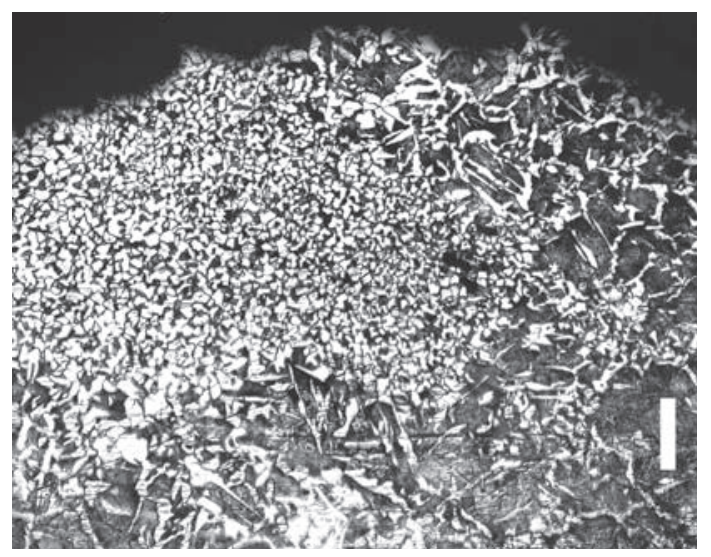

Figure 38. Microstructure of \# A12 : pearlite and ferrite (scale bar $=100$ microns). 

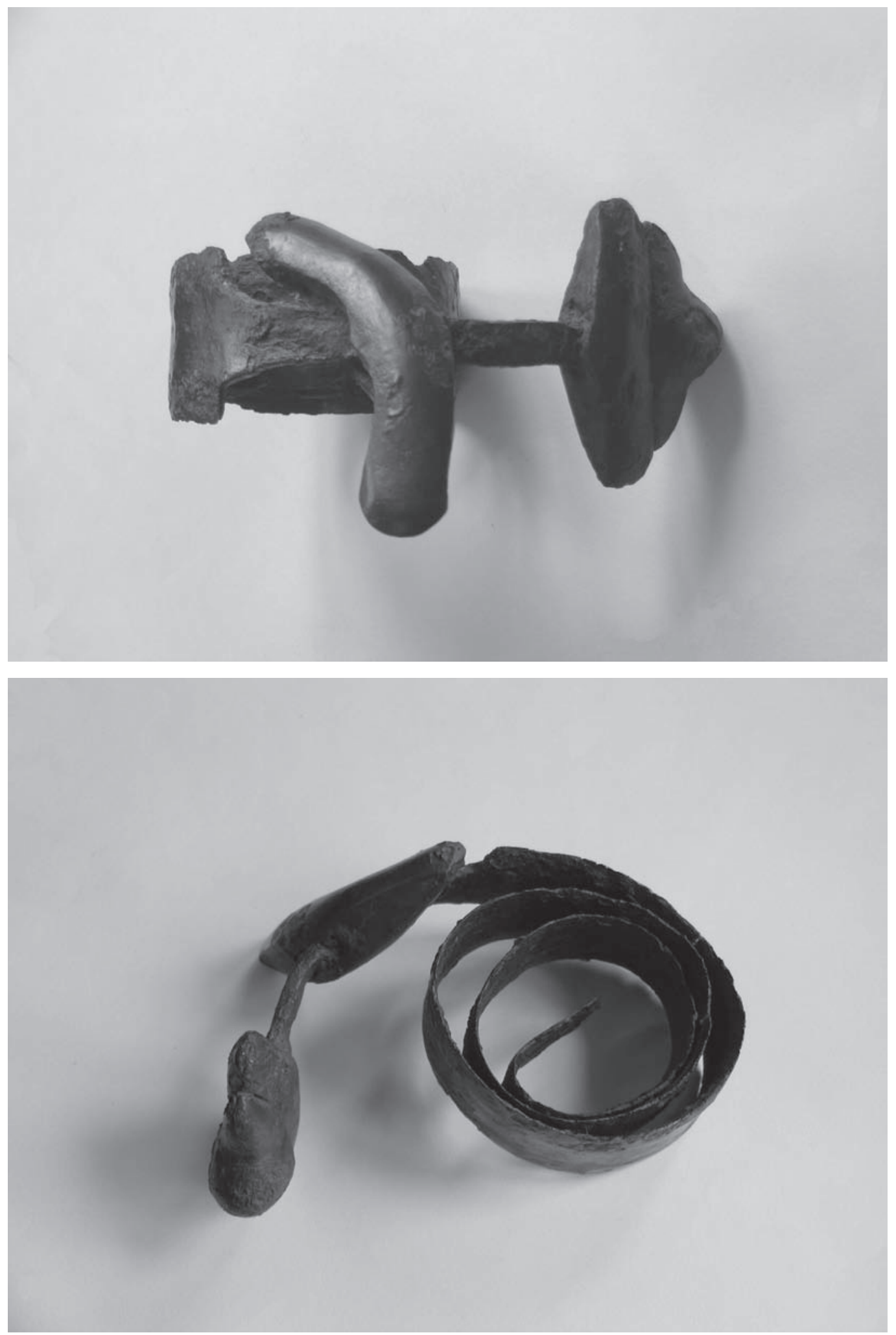

Figure 39 (a,b) Views of sword \# A13 rolled into a coil. 


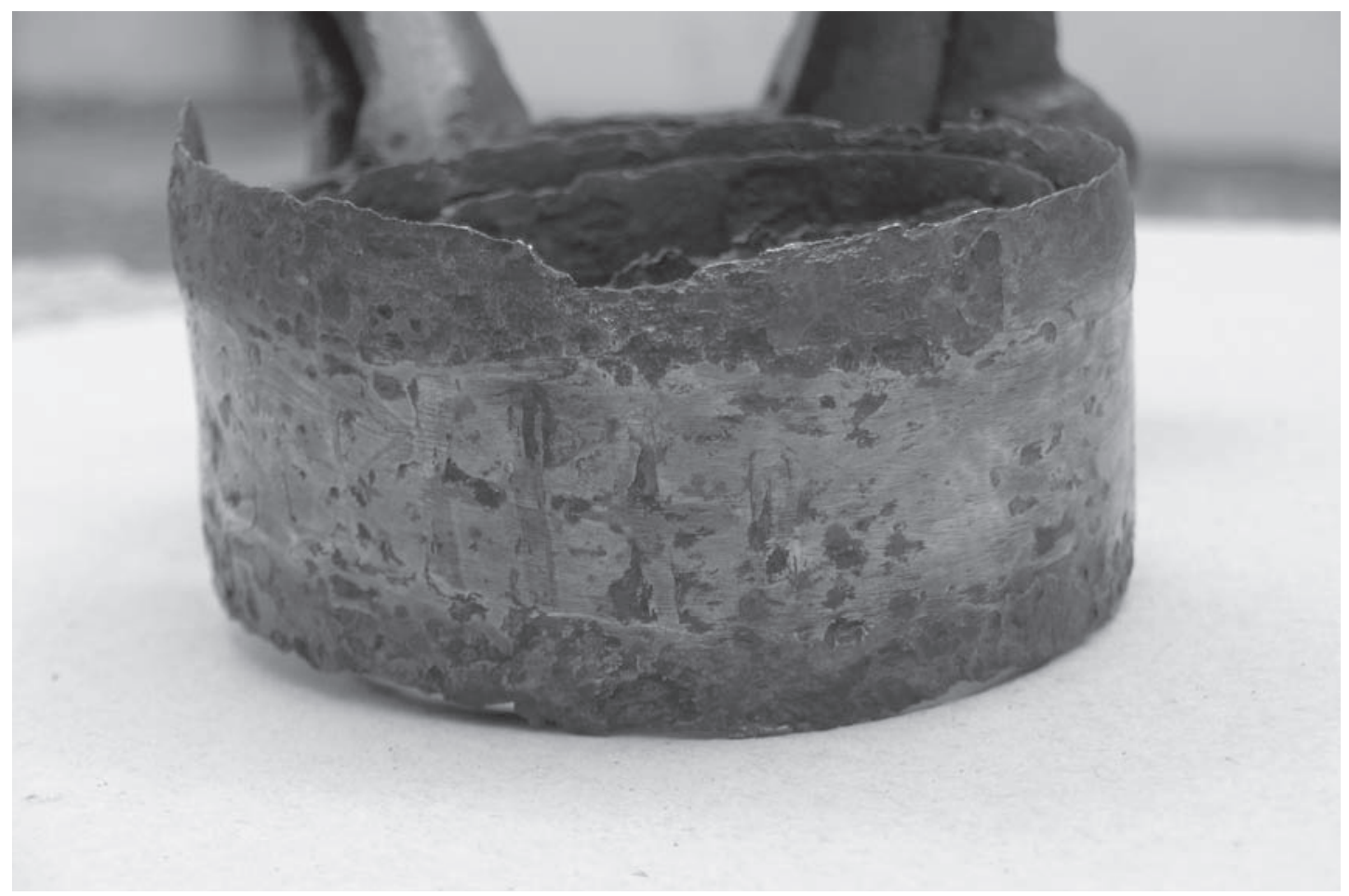

Figure 40. Sword \# A13 after repolishing.

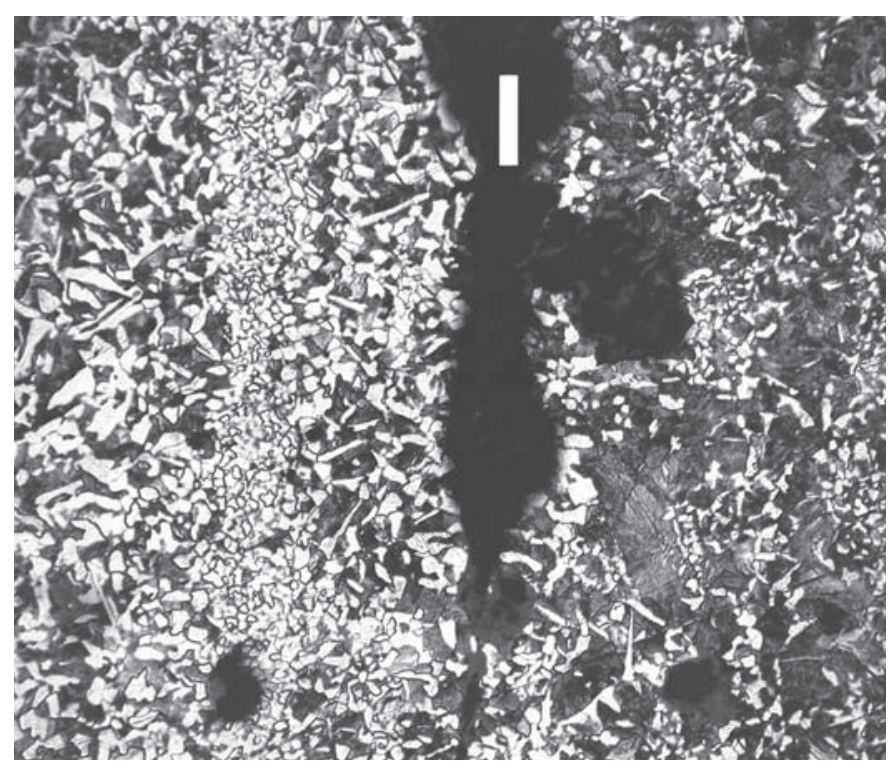

Figure 41. Microstructure of \# A13: pearlite and ferrite with a large corrosion crack (scale bar $=100$ microns). 


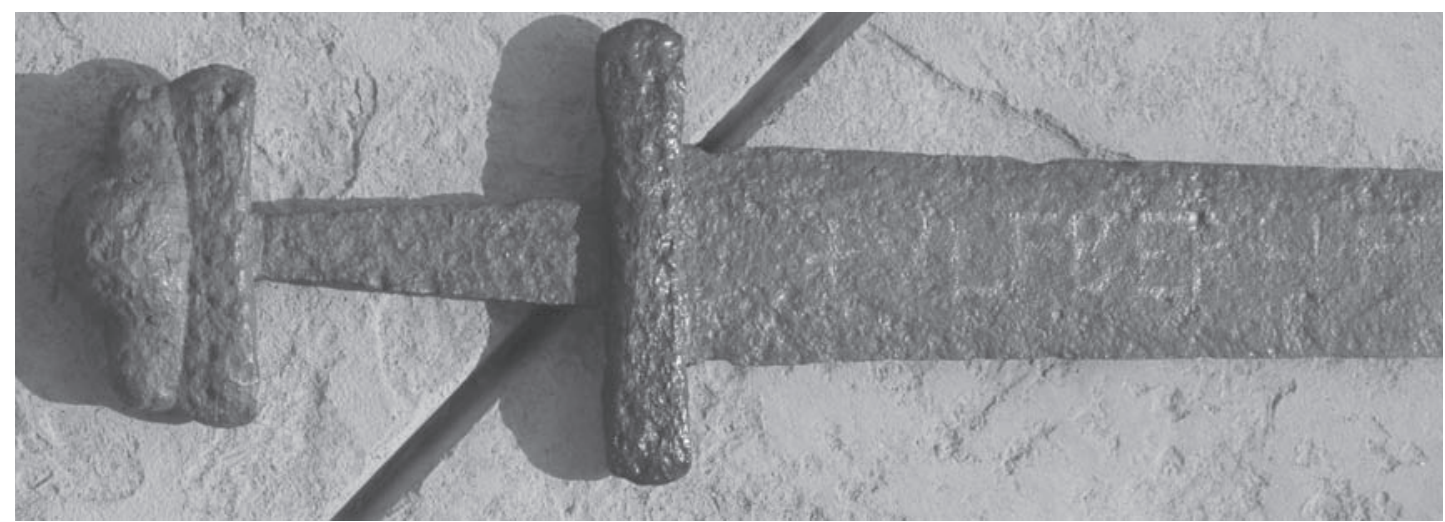

Figure 42. Sword \# A14.

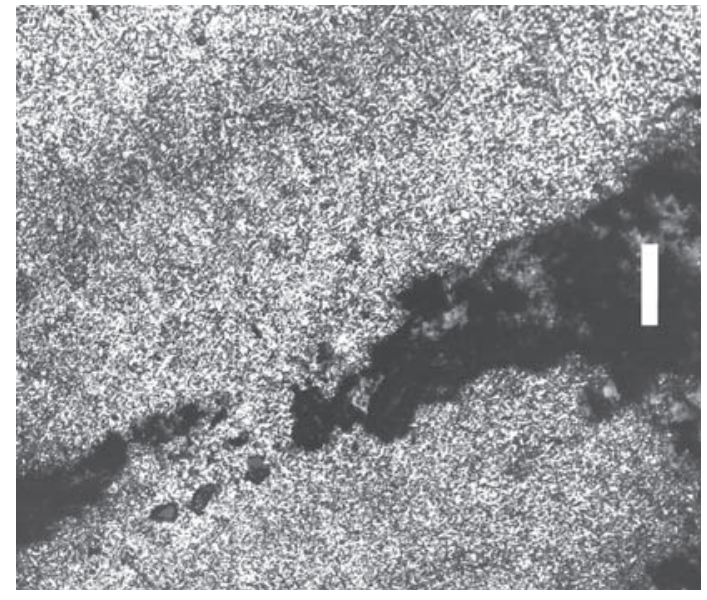

Figure 43. Microstructure of sword \# A14 (scale bar $=100$ microns $)$.

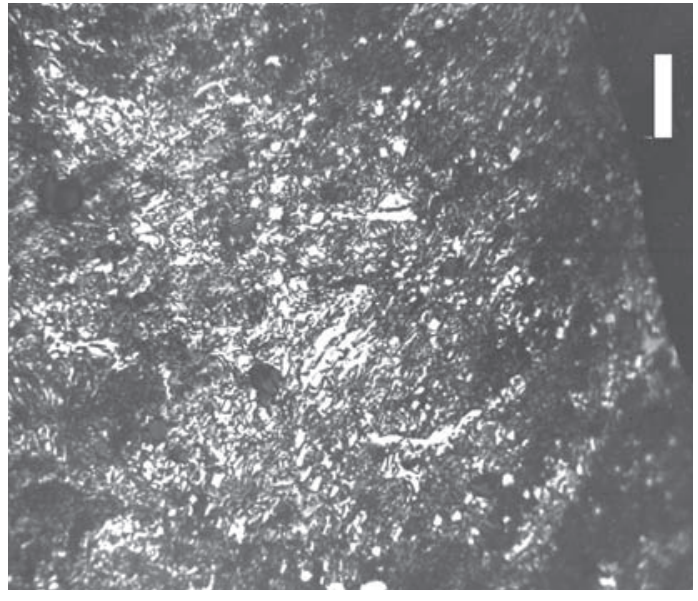

Figure 44. Microstructure of sword \# A14: pearlite and cementite (scale bar $=50$ microns).

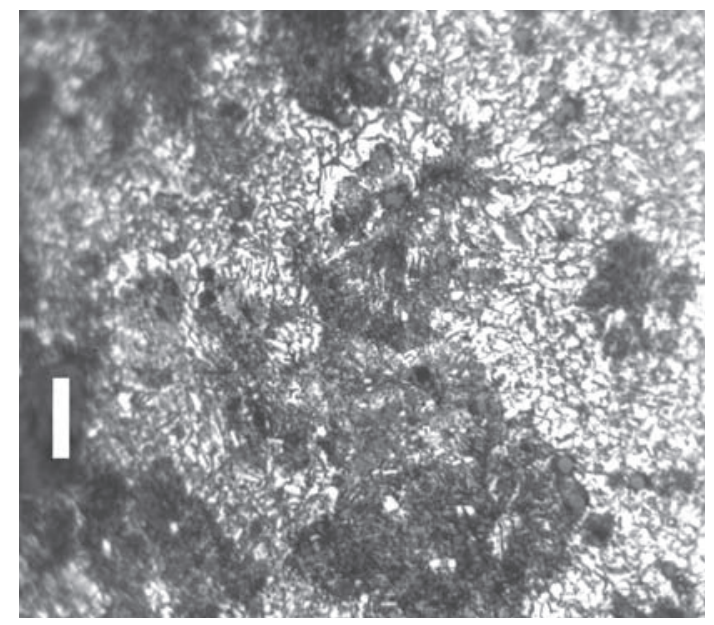

Figure 45. Microstructure of sword \# A14: pearlite and irresolvable carbides. 


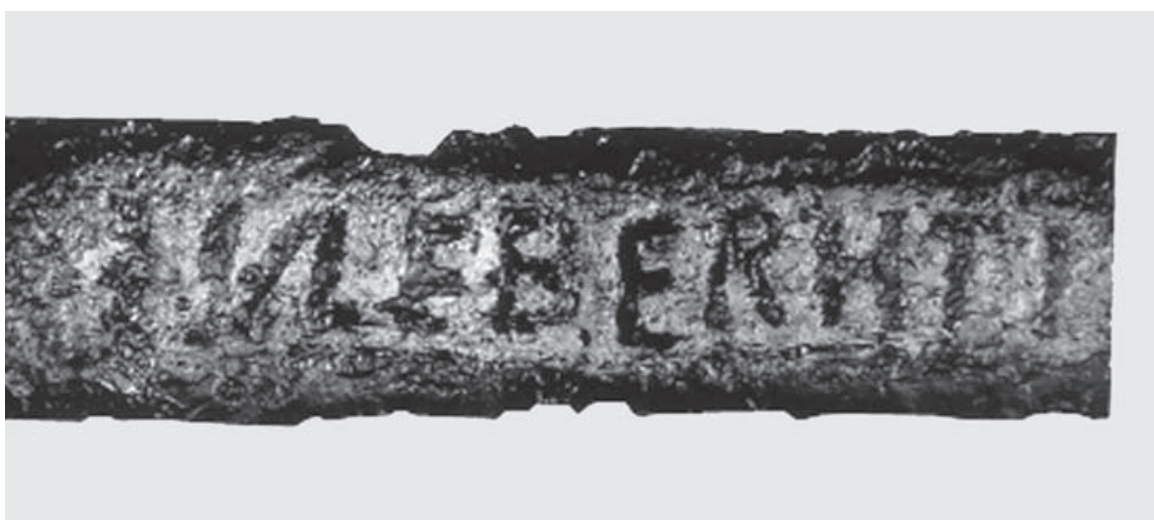

Figure 46. Sword \#B1 from Nemilany (Olomouc).

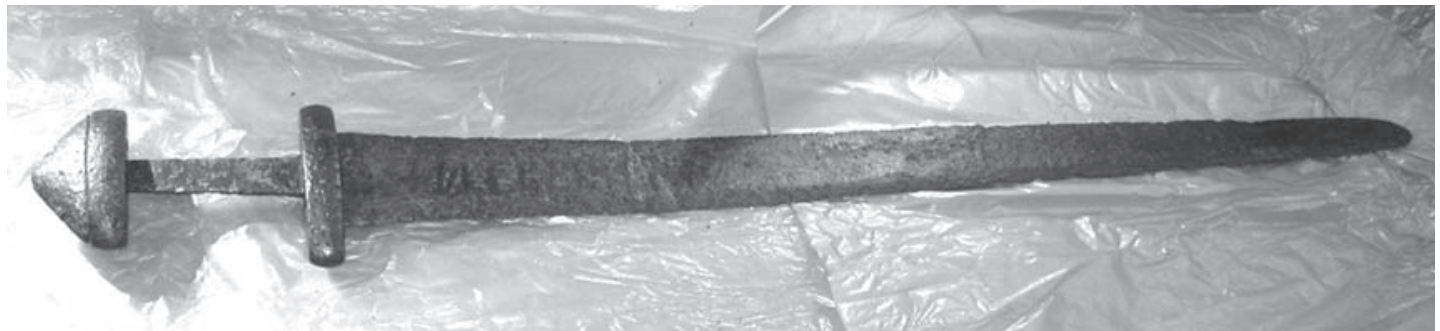

Figure 47. Sword \# B2 from Helsinki.

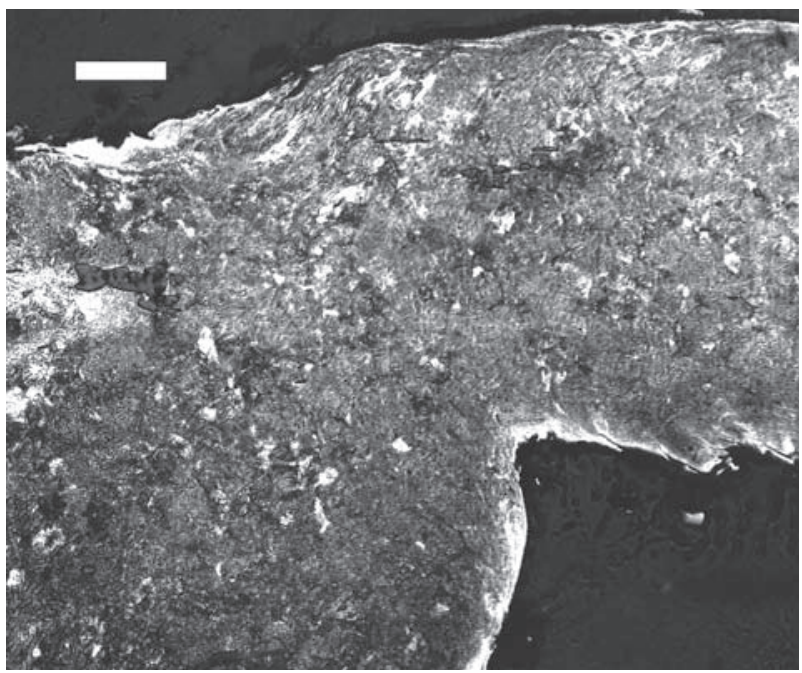

Figure 48. Microstructure of sword \# B2 tempered martensite. (scale bar $=50$ microns). 

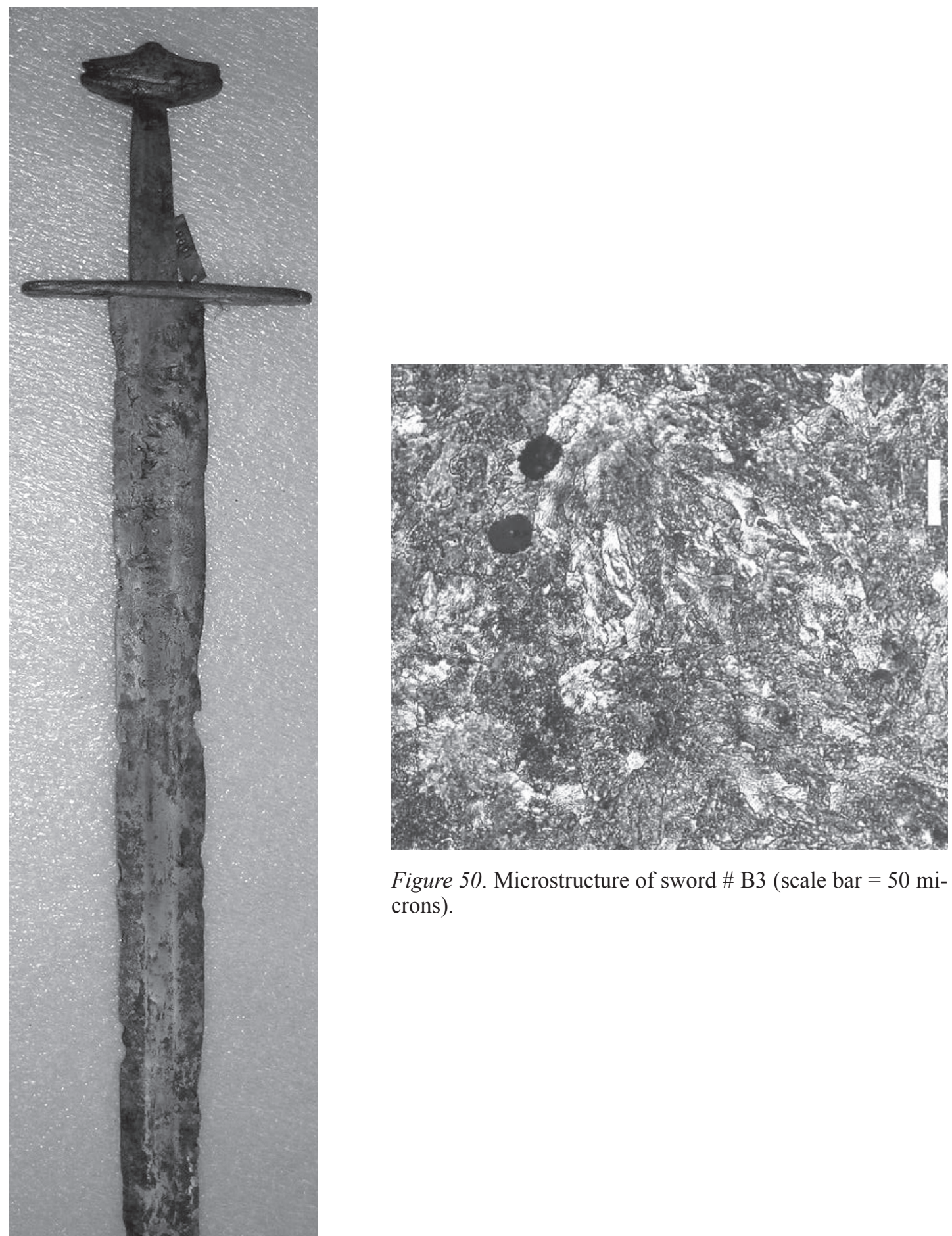

Figure 50. Microstructure of sword \# B3 (scale bar $=50 \mathrm{mi}-$ crons).

Figure 49. Sword \# B3 from Bergen. 


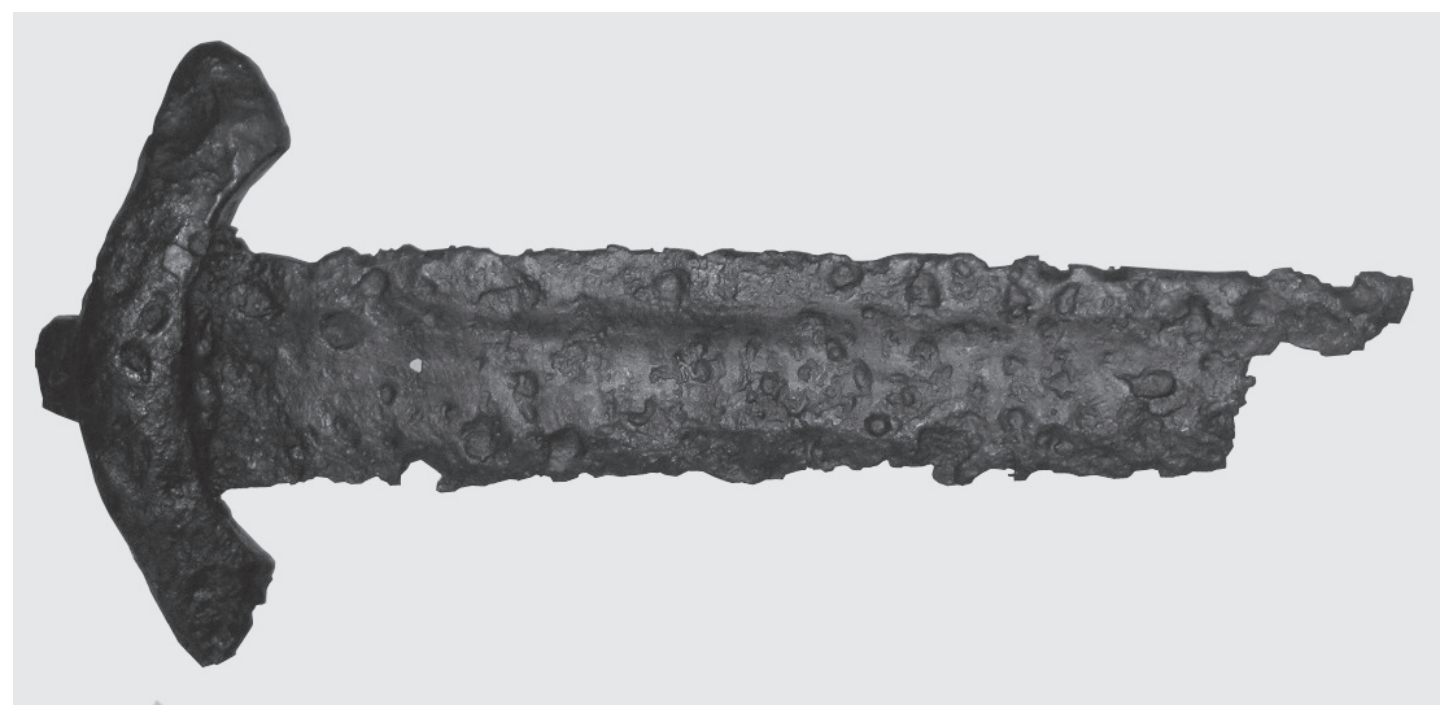

Figure 51. Sword \# B4 from Vesilahti.

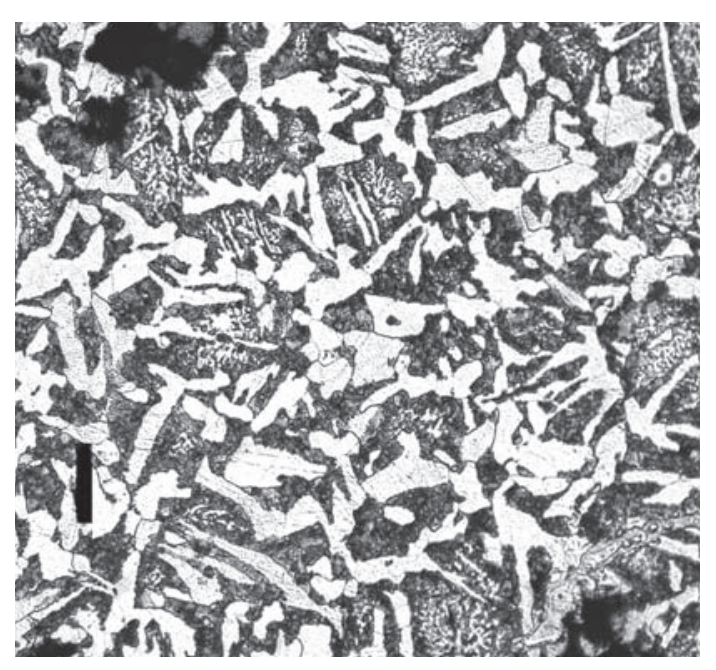

Figure 52. Microstructure of sword \# B4: ferrite and pearlite (scale bar $=50$ microns).

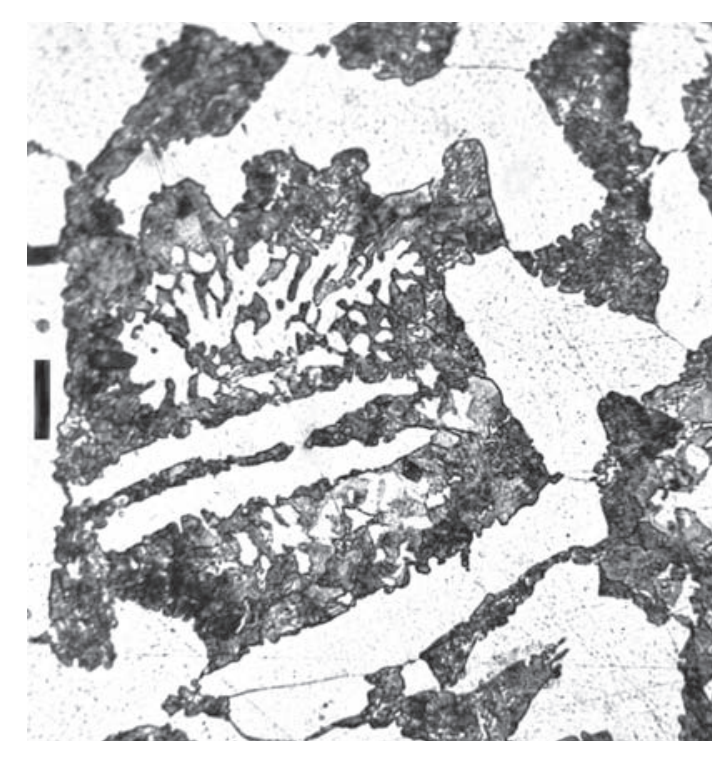

Figure 53. Microstructure of sword \# B4: equiaxed ferrite grains and ferrite within pearlite areas (scale bar $=10$ microns). 


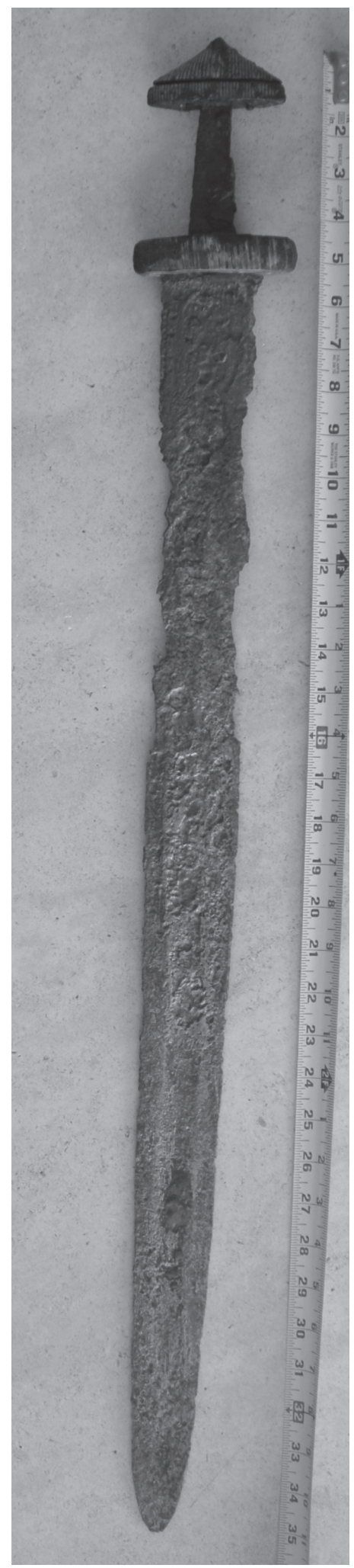

Figure 54. Sword \# B5.

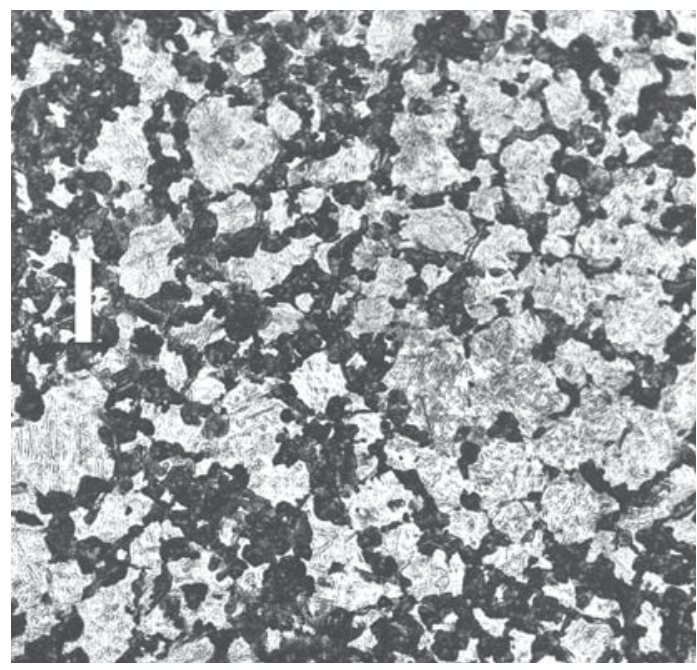

Figure 55. Microstructure of sword \# B5: tempered martensite and nodular pearlite.

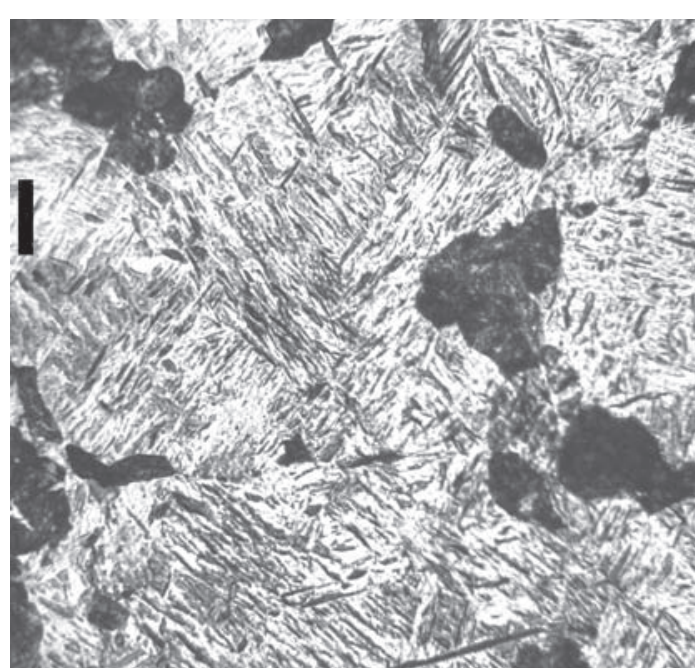

Figure 56. Microstructure of sword \# B5: tempered martensite and nodular pearlite. (scale bar $=10$ microns). 


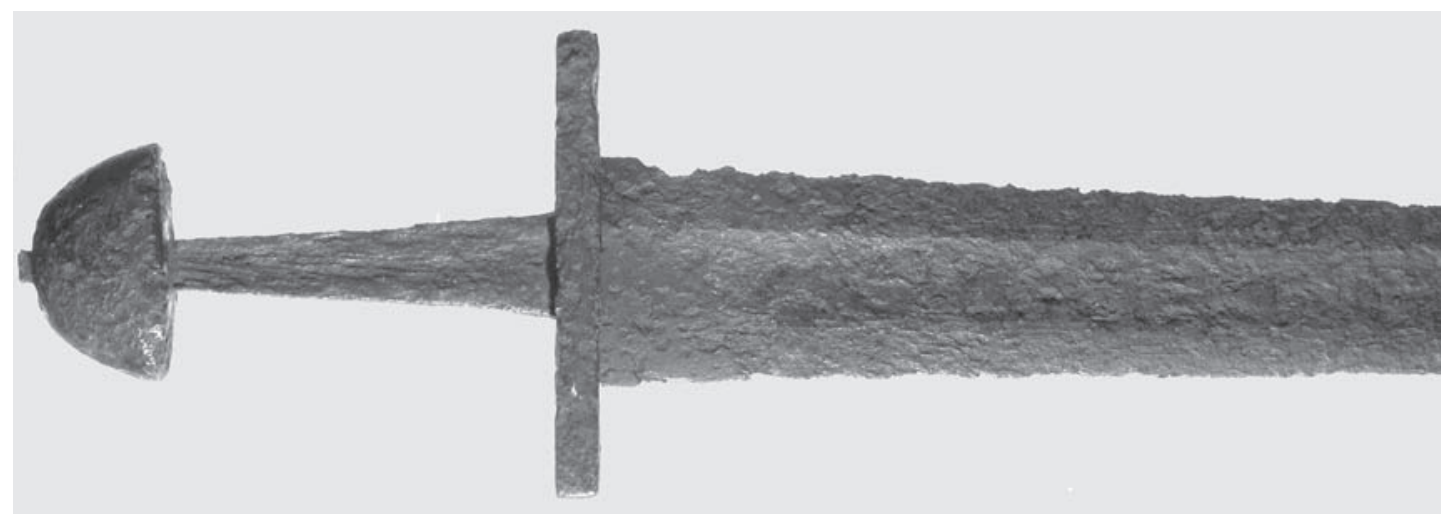

Figure 57. Sword \# C1.

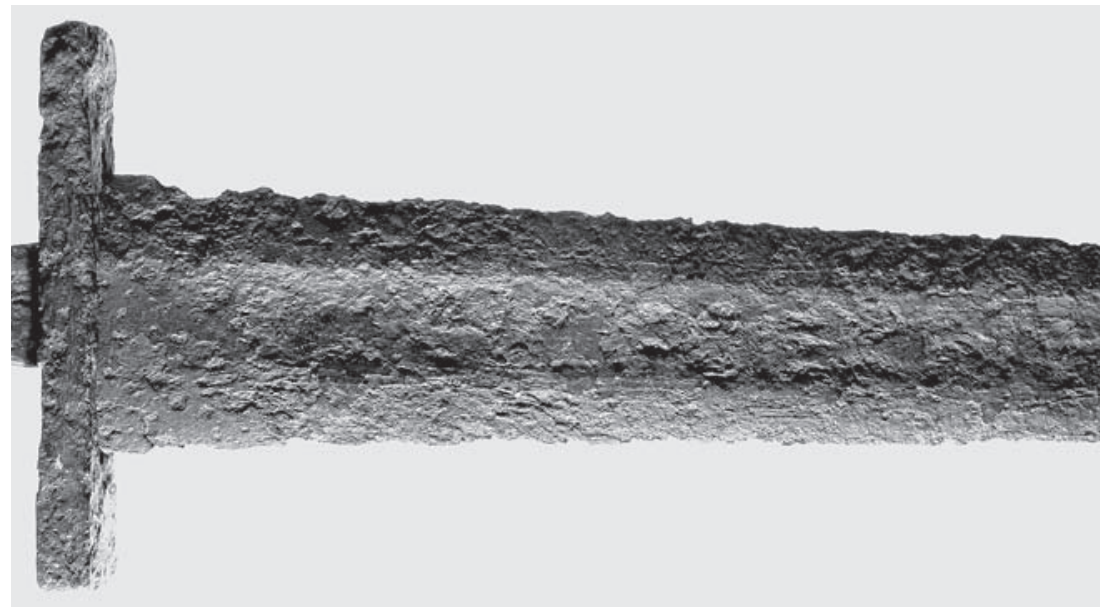

Figure 58. Sword \# C1 inscription.

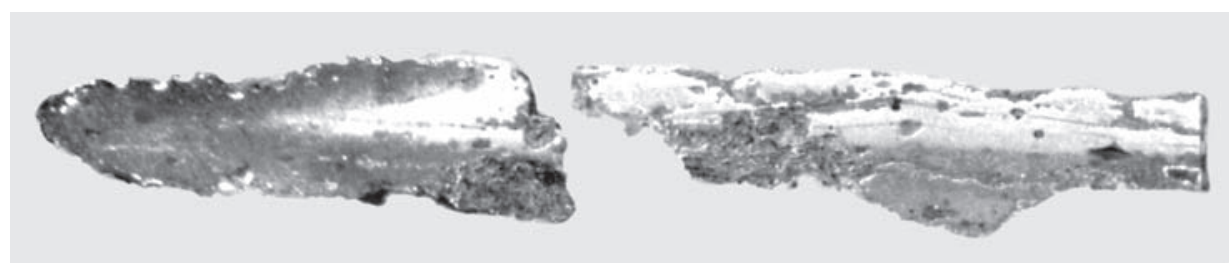

Figure 59. Cross-section of edge of \# C1.

Figure 60. Microstructure of edge of \# C1.

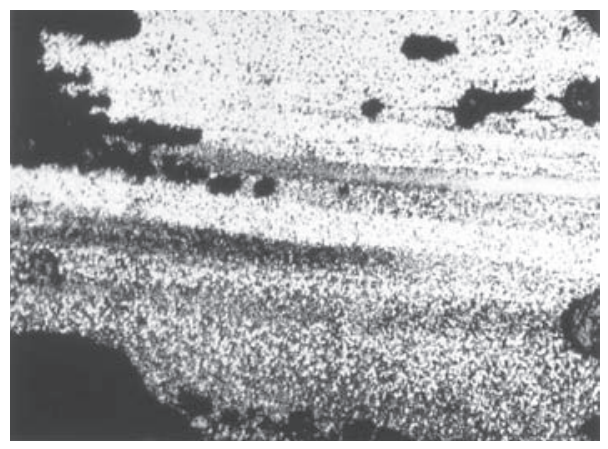




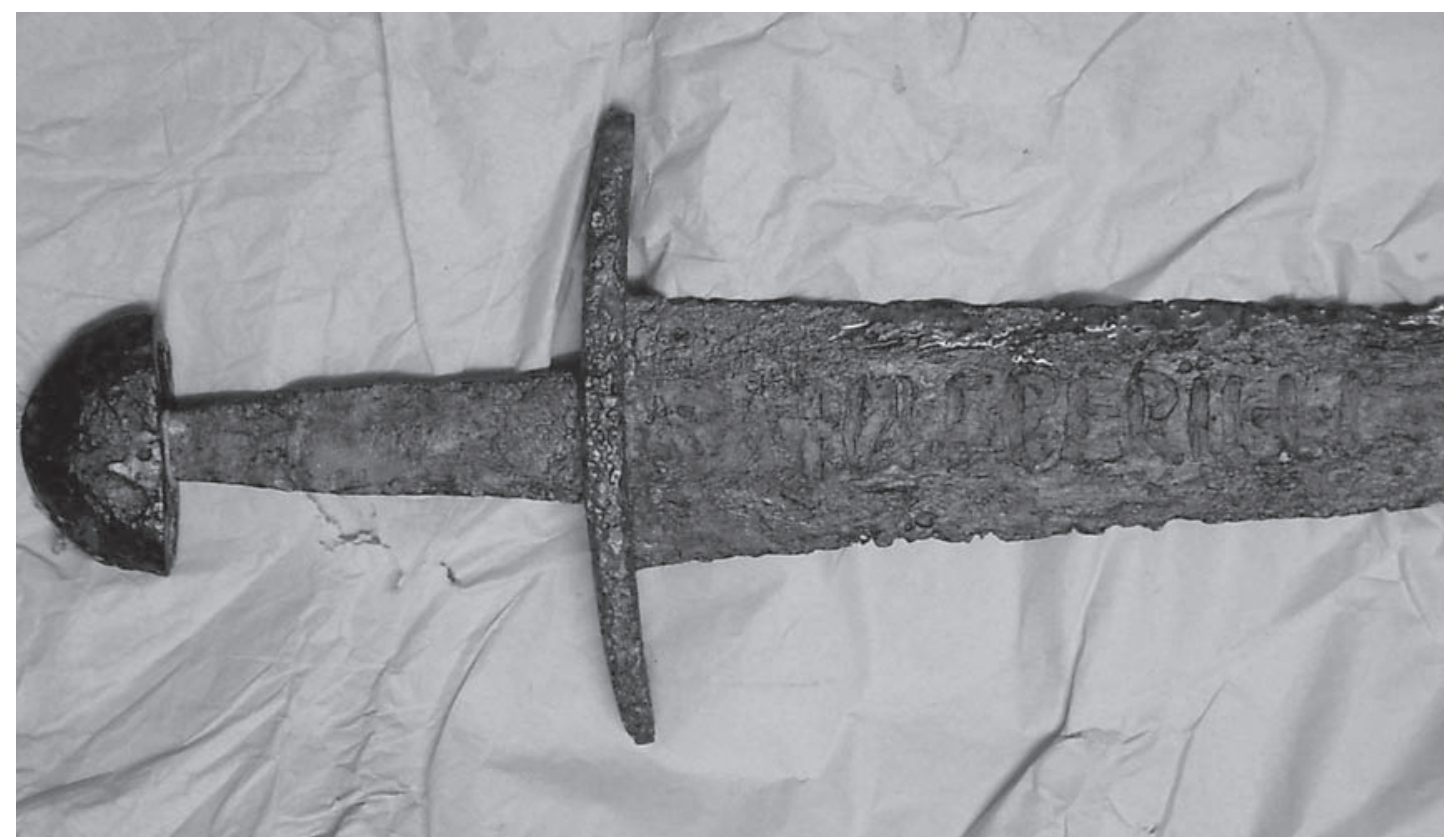

Figure 61. Sword \# C2.

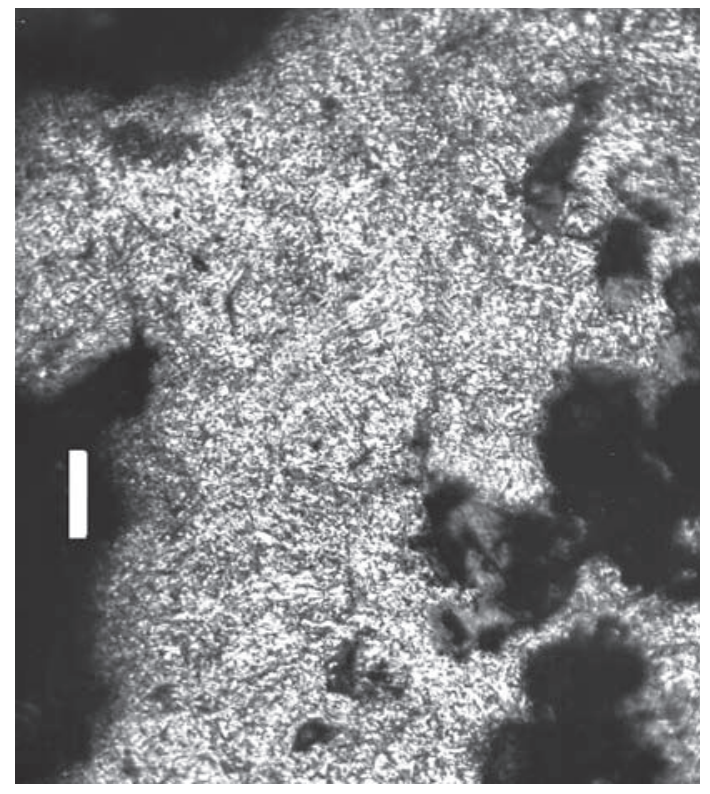

Figure 62. Microstructure of sword \# C2: (scale bar $=50$ microns).

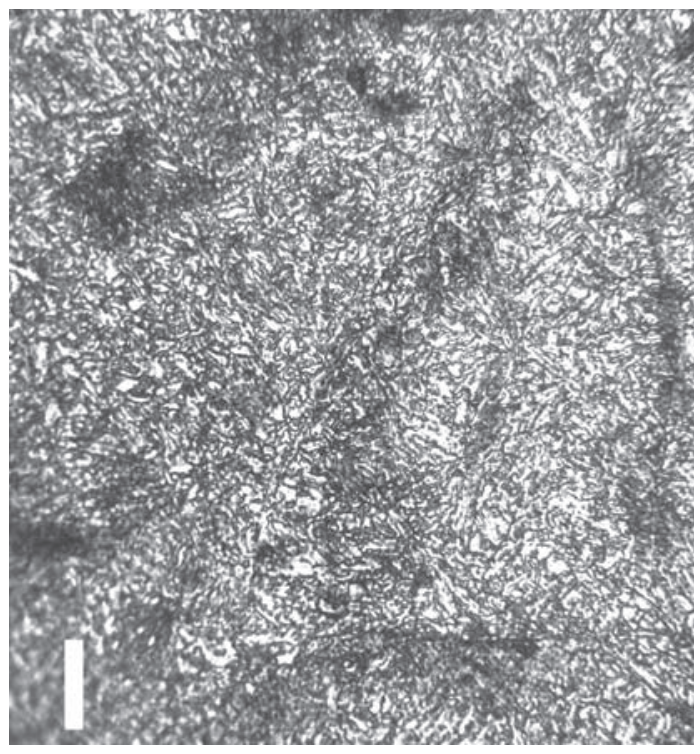

Figure 63. Microstructure of sword \# C2: acicular martensite (?) and bainite. 


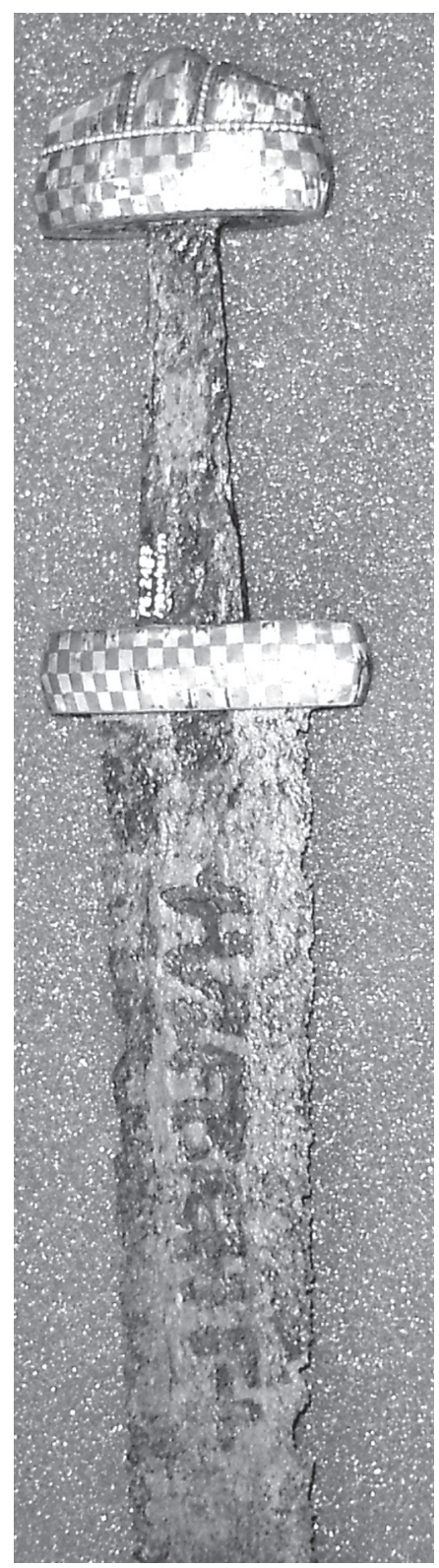

Figure 64. Sword \# C3 (from Mannheim).

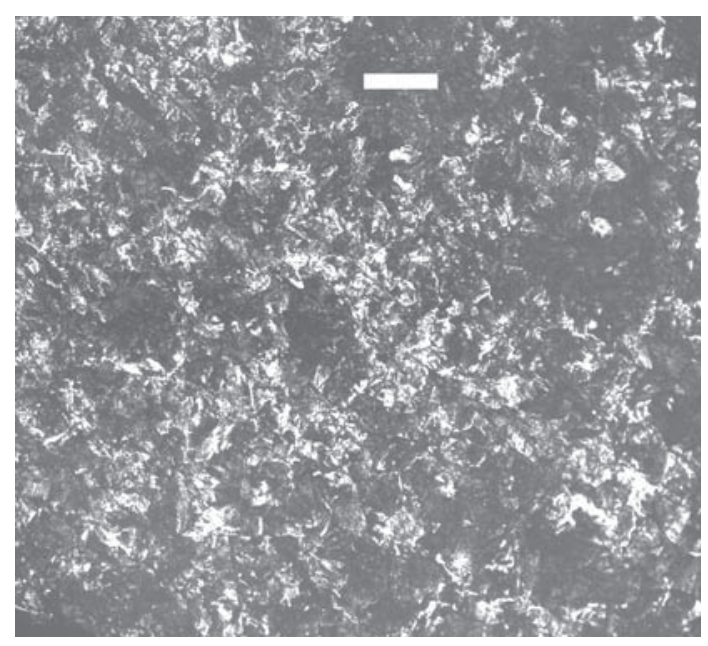

Figure 65. Microstructure of sword \# C3 (scale bar $=50$ microns).

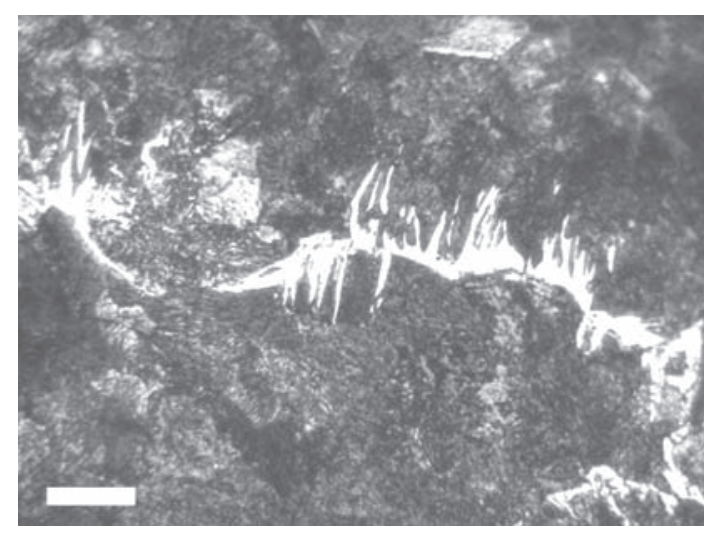

Figure 66. Microstructure of sword \# C3: pearlite, irresolvable in places, and spiny ferrite (scale bar $=10$ microns). 


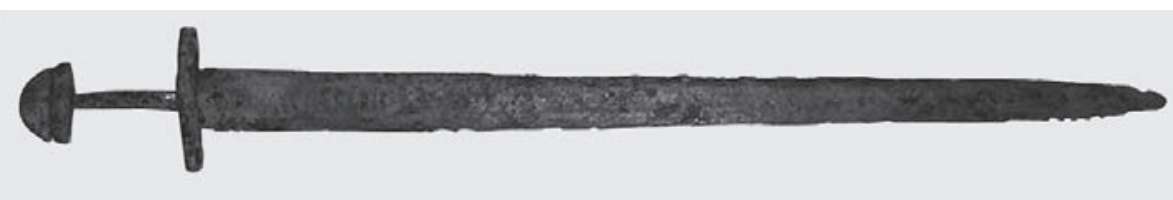

Figure 67. Sword \# C4 from the River Nene.

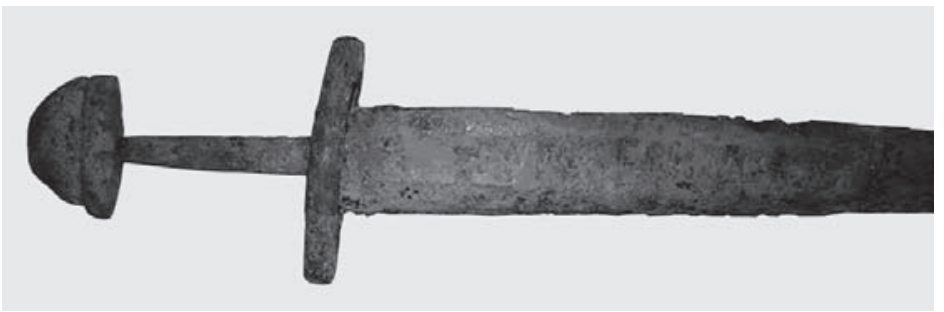

Figure 68. "Ulfberht" inscription on \# C4.

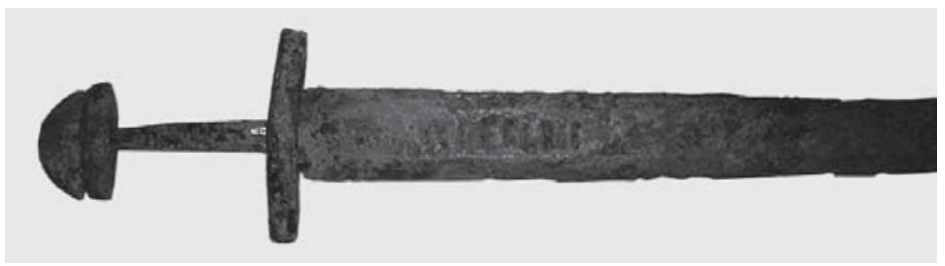

Figure 69. "Ingelrii" inscription on \# C4.

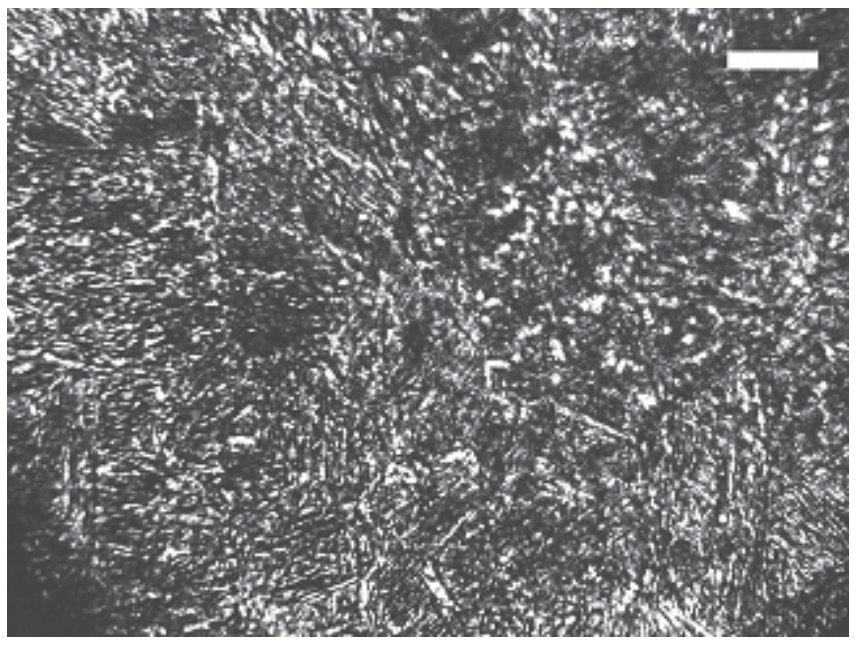

Figure 70. Microstructure of \# C4: tempered martensite and bainite. (scale bar $=10$ microns). 


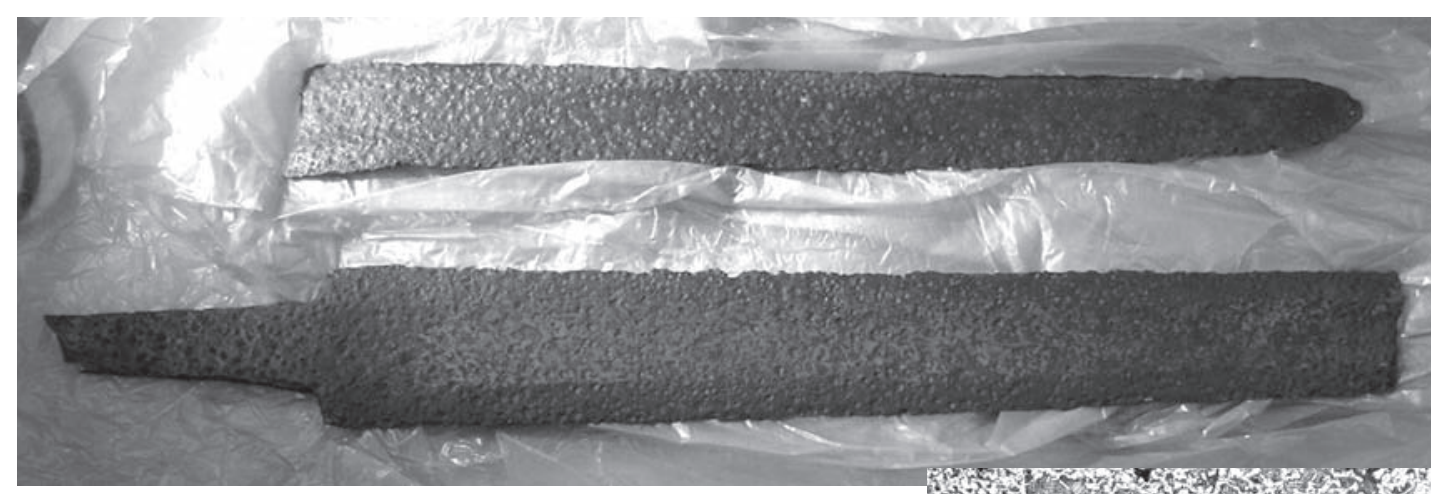

Figure 71. Fragments of sword \# C5 from Helsinki.

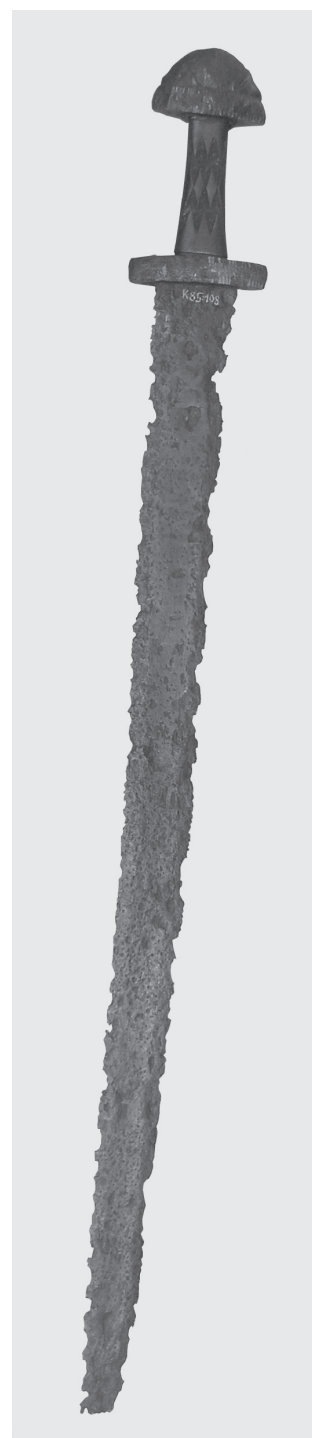

Figure 72. Microstructure of sword \# C5 : tempered martensite and ferrite (scale bar $=50$ microns).

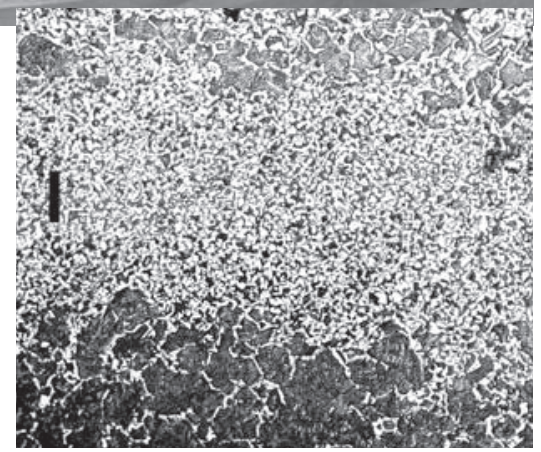

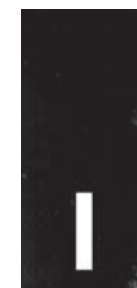

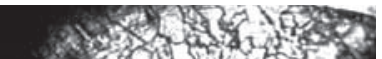

3. - An knt

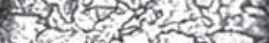
3 in $y=5$ ? Gen

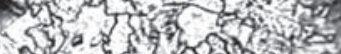
72 है

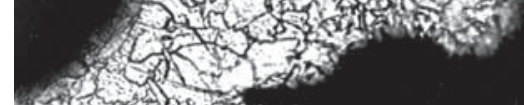
से 3.

Figure 74. Microstructure of \# C6 body: (scale bar $=50$ microns).

Figure 76. Microstructure of \# C6 edge: (scale bar $=10$ microns).

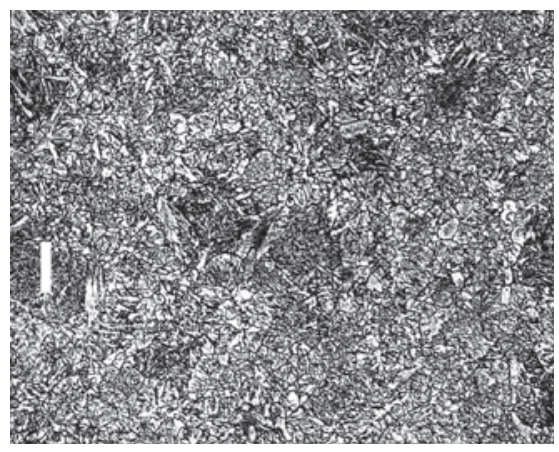

Figure 75. Microstructure of \# C6 edge: (scale bar $=50$ microns).

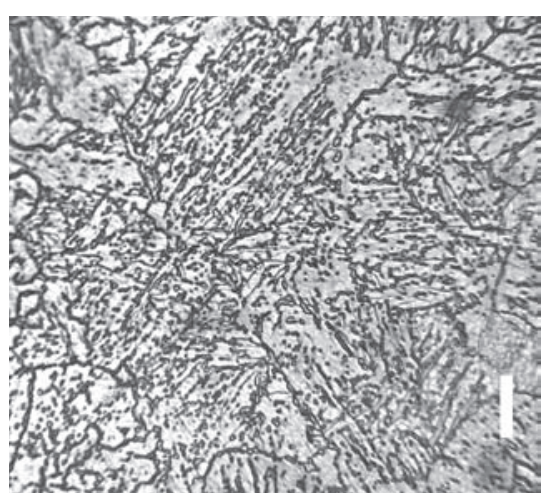

Figure 73. Sword \# C6 from Saaremaa. 


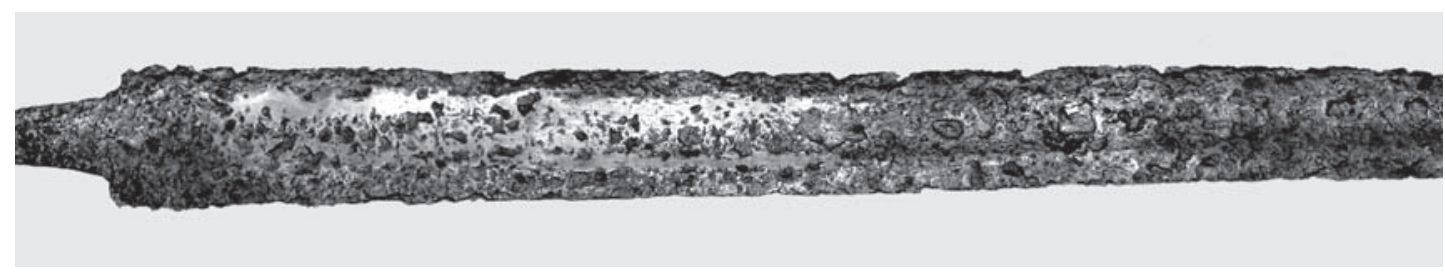

Figure 77. Sword \# C7 from Saaremaa.

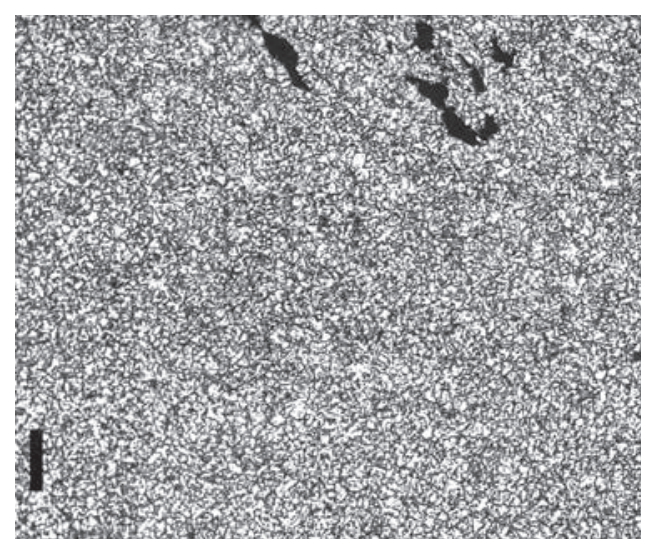

Figure 78. Microstructure of specimen from tip of \# C7: (scale bar $=50$ microns).

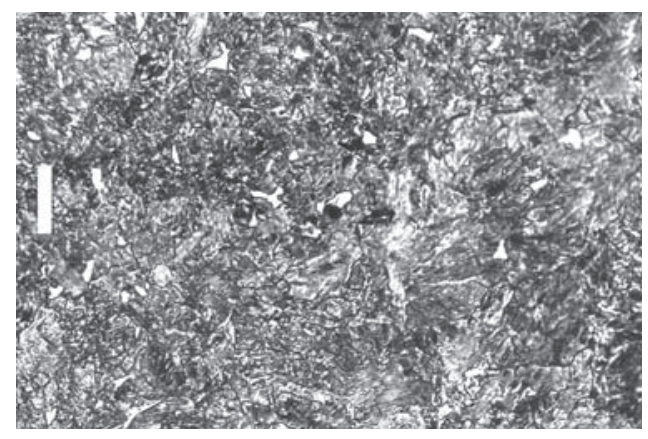

Figure 80. Microstructure of specimen from edge of \# C7: (scale bar $=50$ microns).

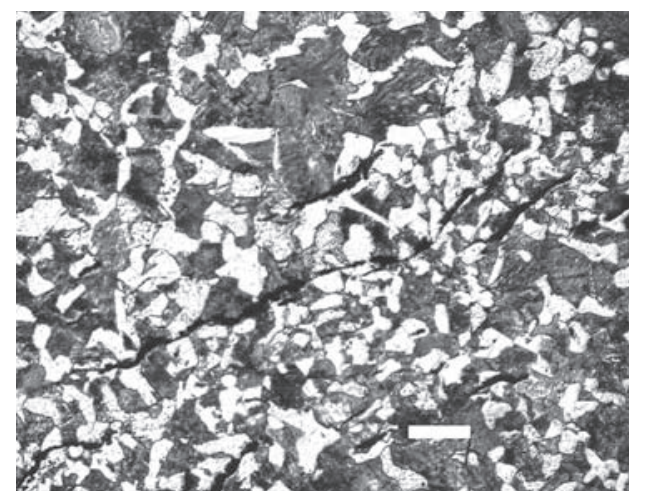

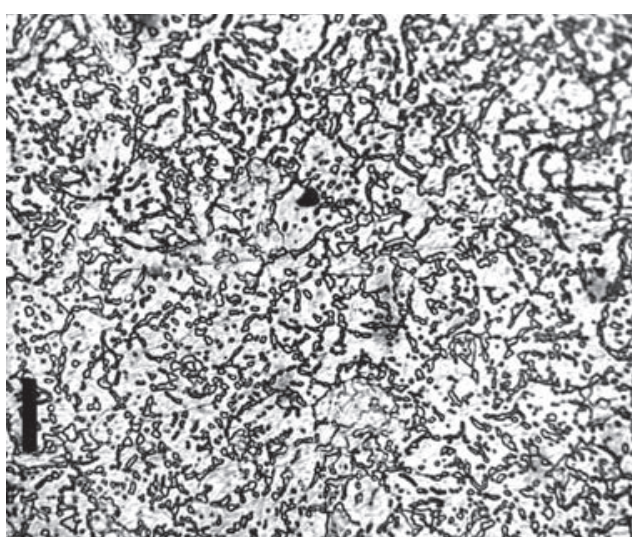

Figure 79. Microstructure of specimen from tip of \# C7: (scale bar $=10$ microns).

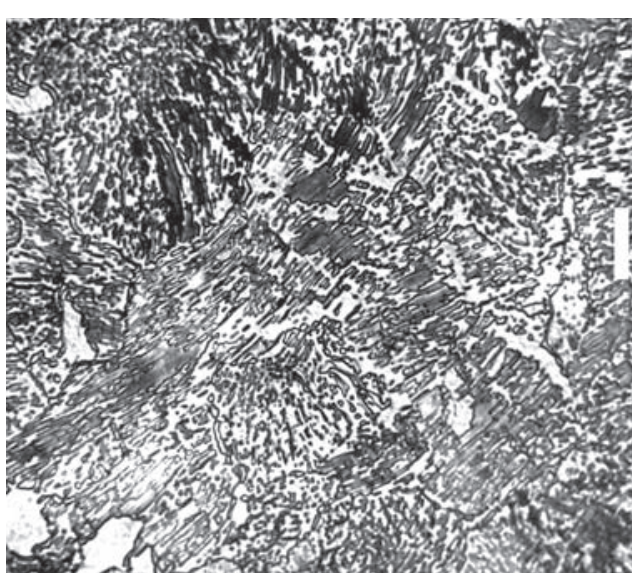

Figure 81. Microstructure of specimen from edge of \# C7: (scale bar $=10$ microns).

Figure 82. Microstructure of specimen from centre of \# C7: (scale bar $=50$ microns). 


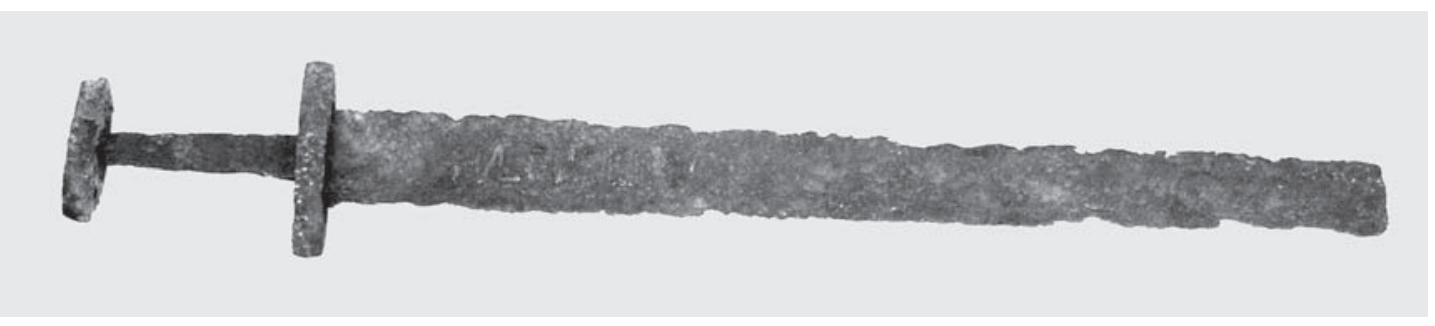

Figure 83. Sword \# C8 from Saaremaa.

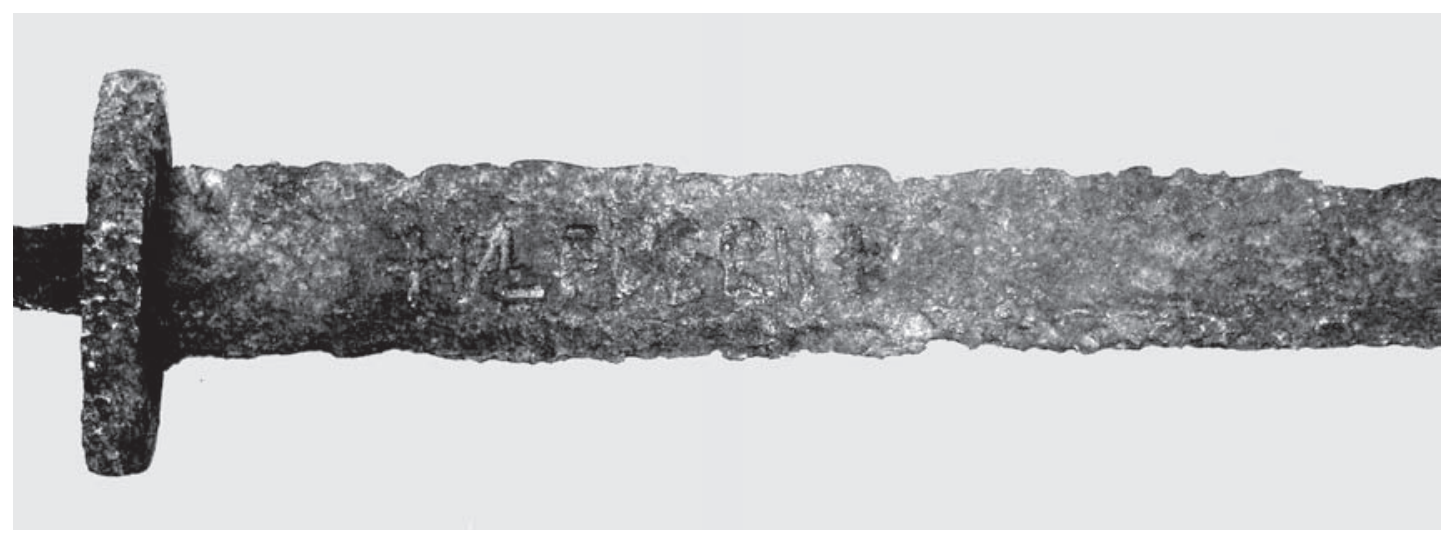

Figure 84. The inscription on sword \# C 8.

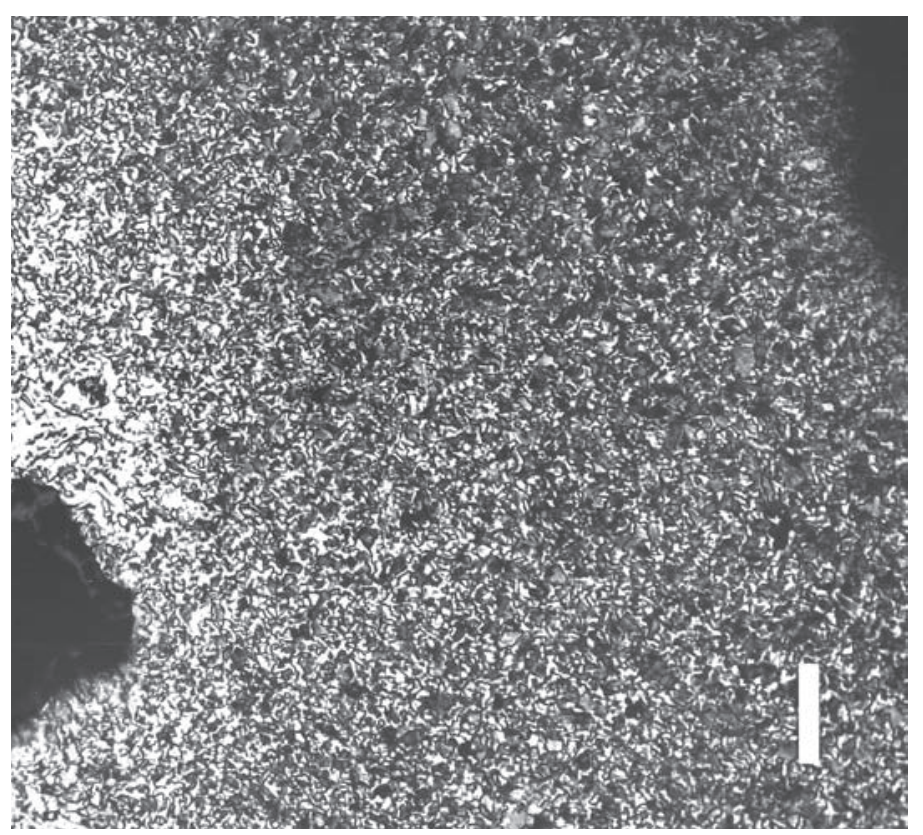

Figure 85. Microstructure of \# C8: pearlite and ferrite, with very few slag inclusions. 

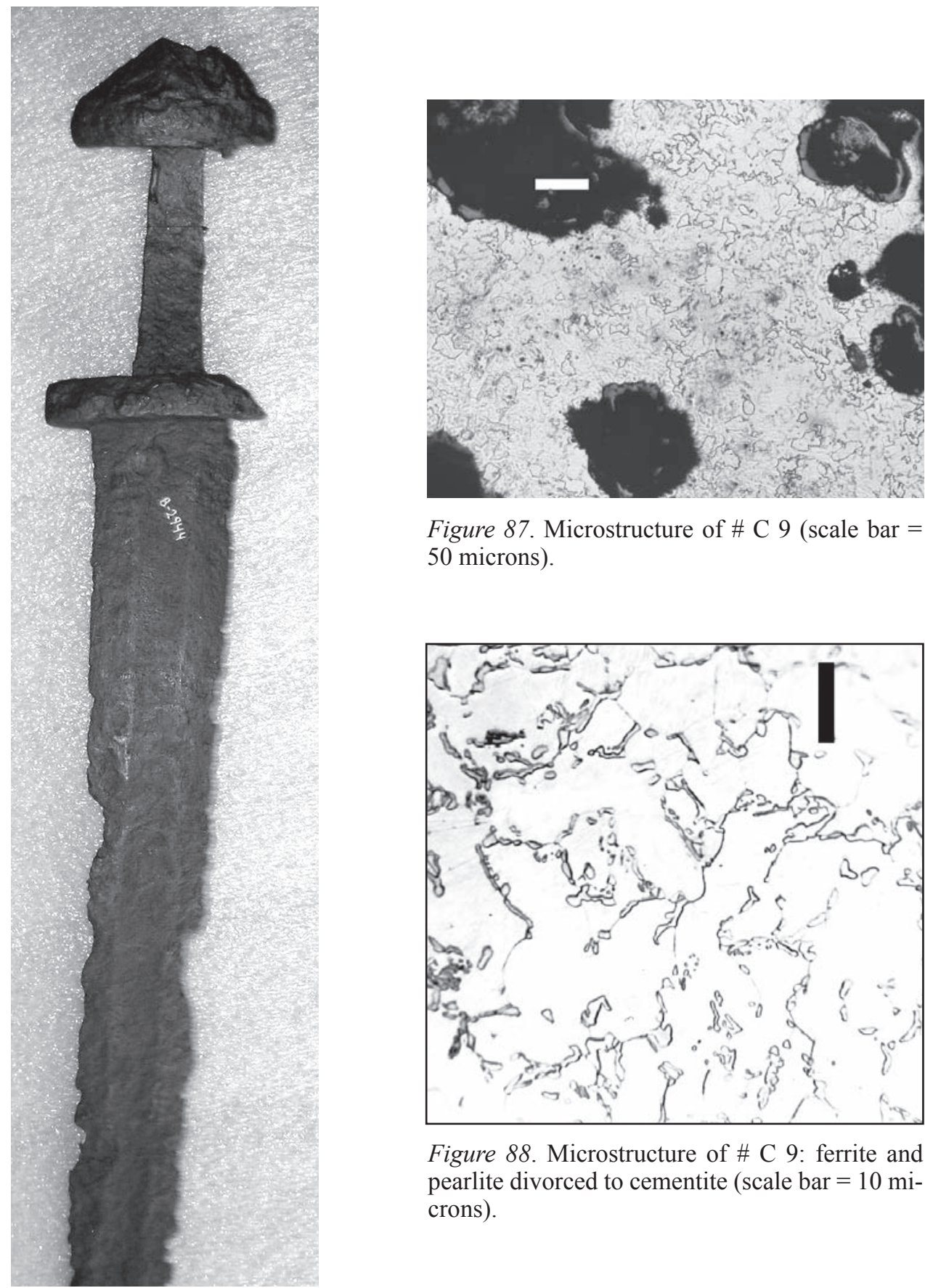

Figure 87. Microstructure of \# C 9 (scale bar $=$ 50 microns).

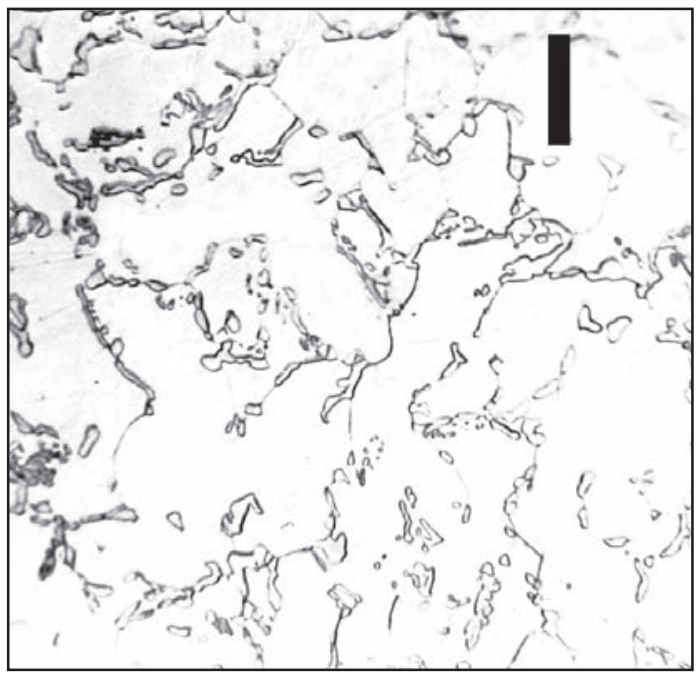

Figure 88. Microstructure of \# C 9: ferrite and pearlite divorced to cementite (scale bar $=10 \mathrm{mi}$ crons).

Figure 86. Sword \# C9 from Bergen. 


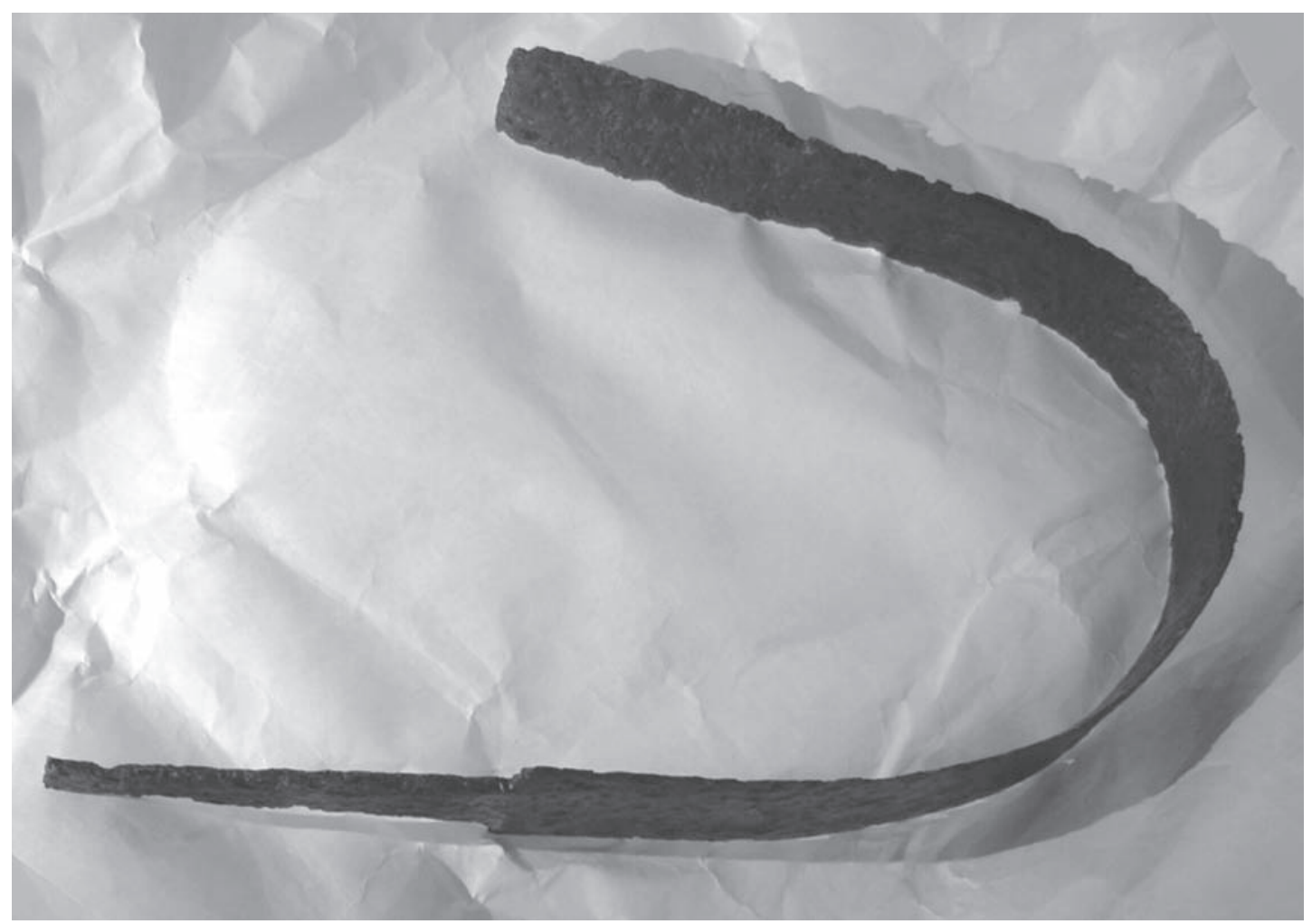

Figure 89. Sword \# C10 from Hollola.

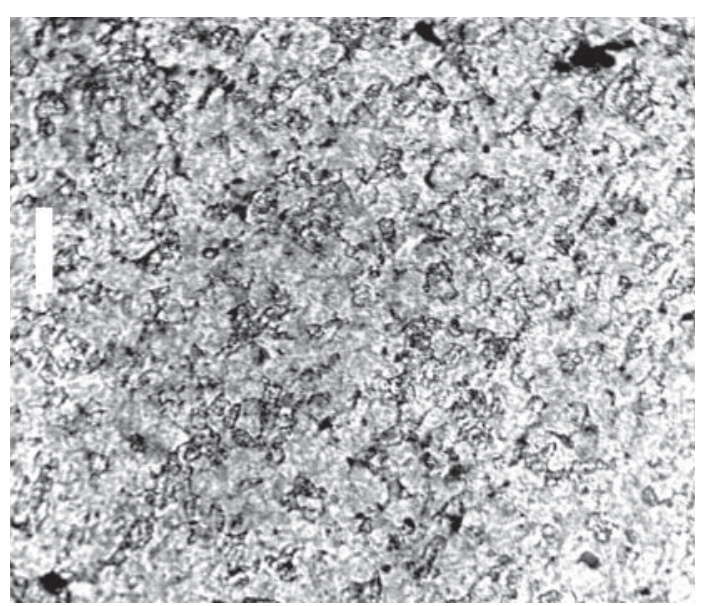

Figure 90. Microstructure of \# C10 (scale bar 50 microns).

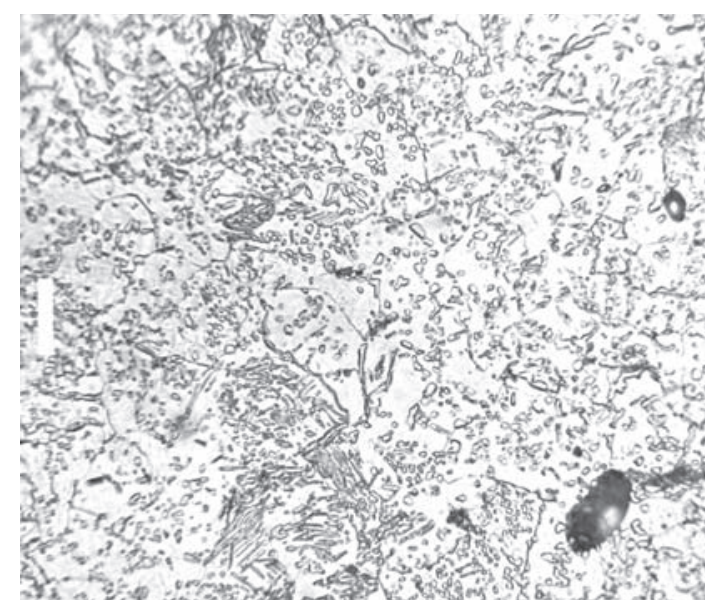

Figure 91. Microstructure of \# C10: ferrite and pearlite divorced to cementite. 


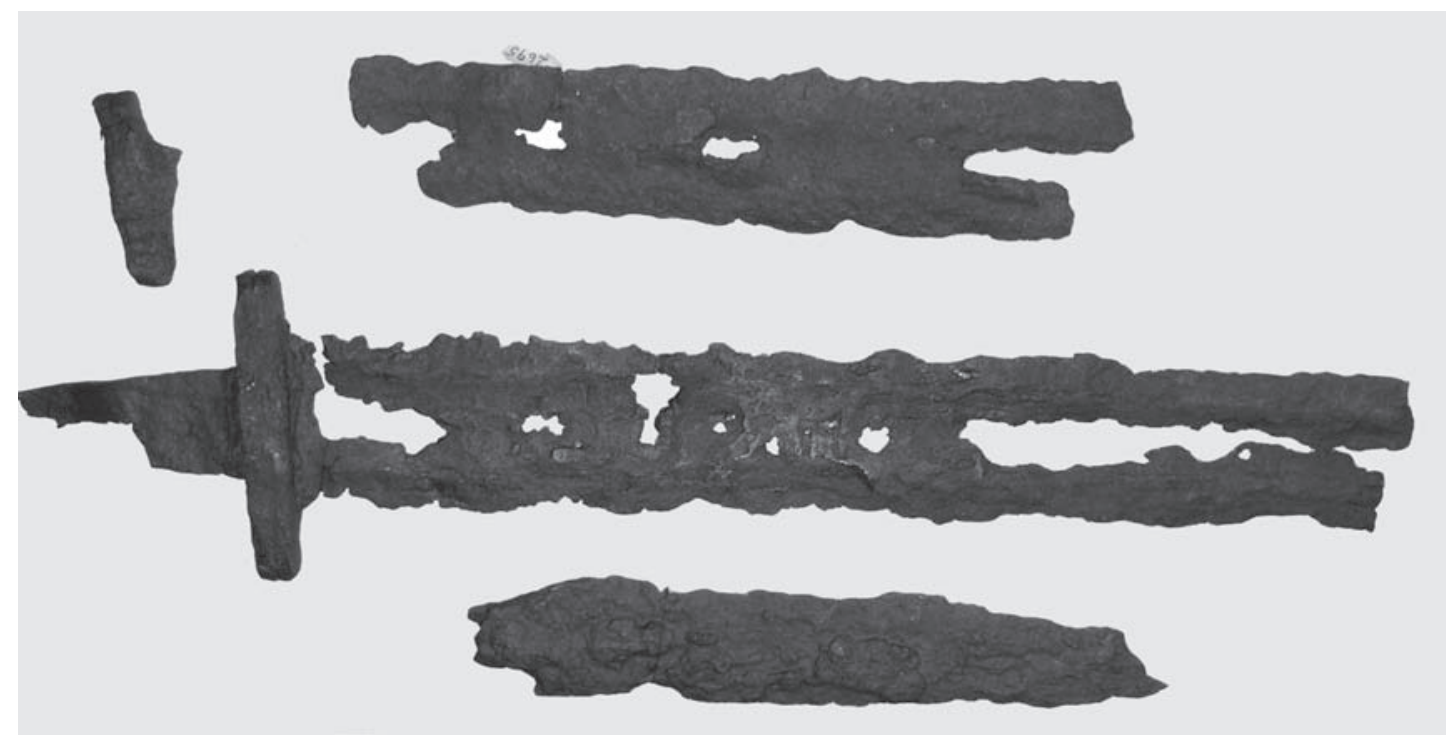

Figure 92. Sword \# C11 from Bergen.

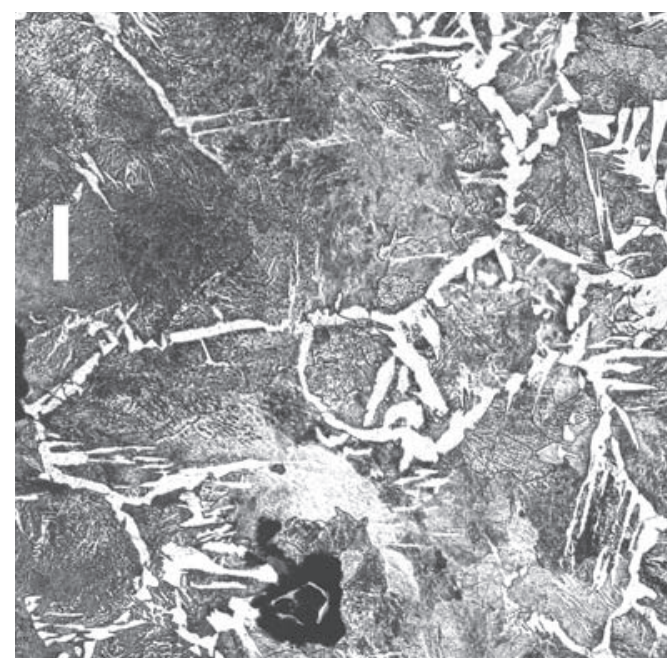

Figure 93. Microstructure of \# C11: pearlite and ferrite (scale bar 50 microns).

Figure 95. Microstructure of \# C12: pearlite, slightly divorced, and ferrite (scale bar 10 microns).

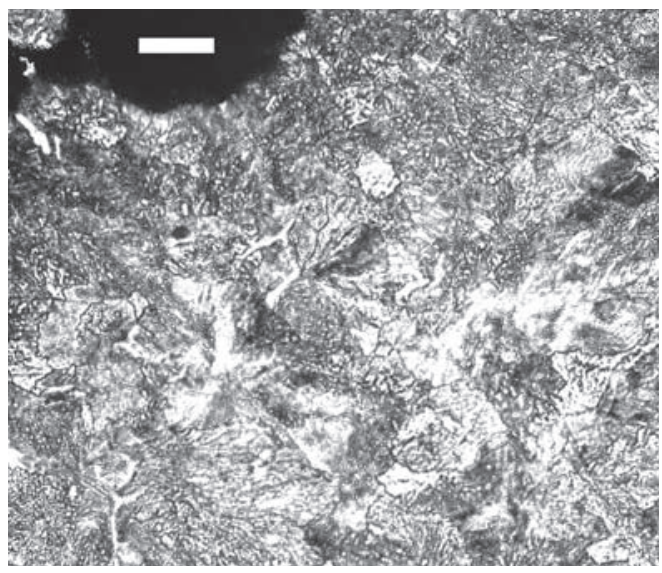

Figure 94. Microstructure of \# C12 (scale bar 50 microns).

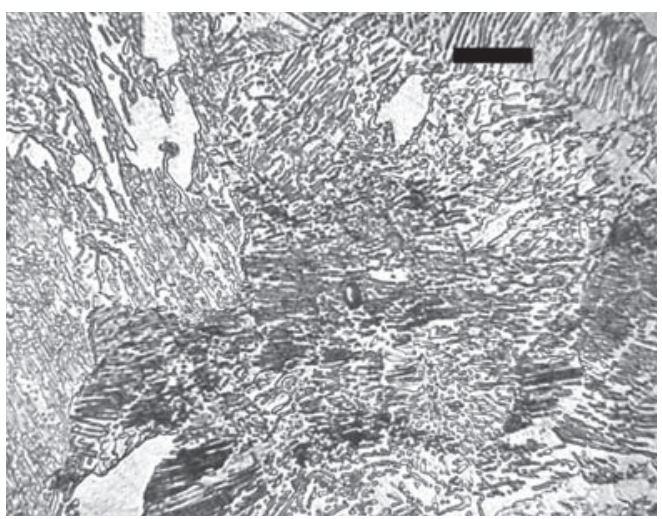




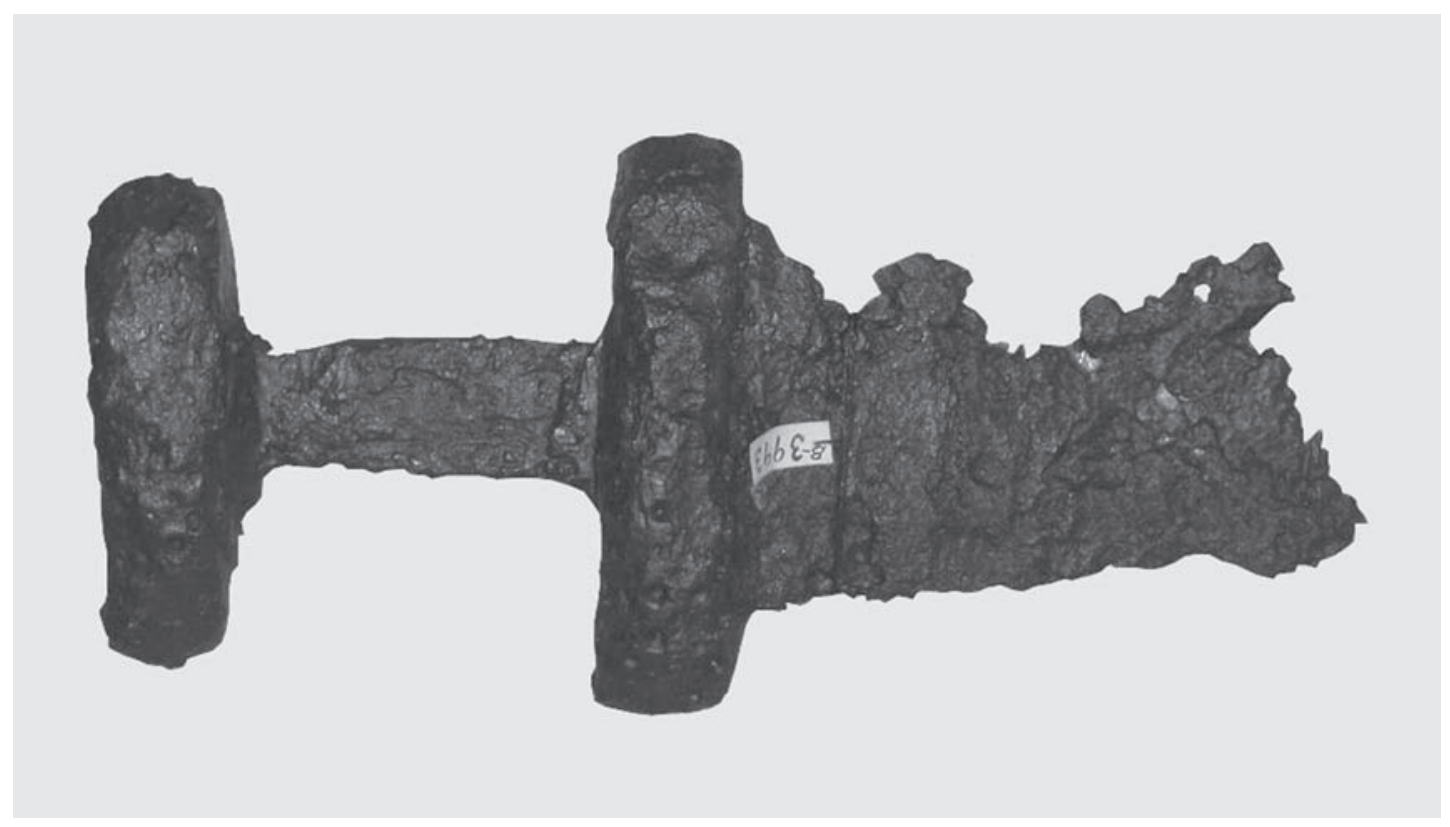

Figure 96. (remains of) sword \# C13 from Bergen.

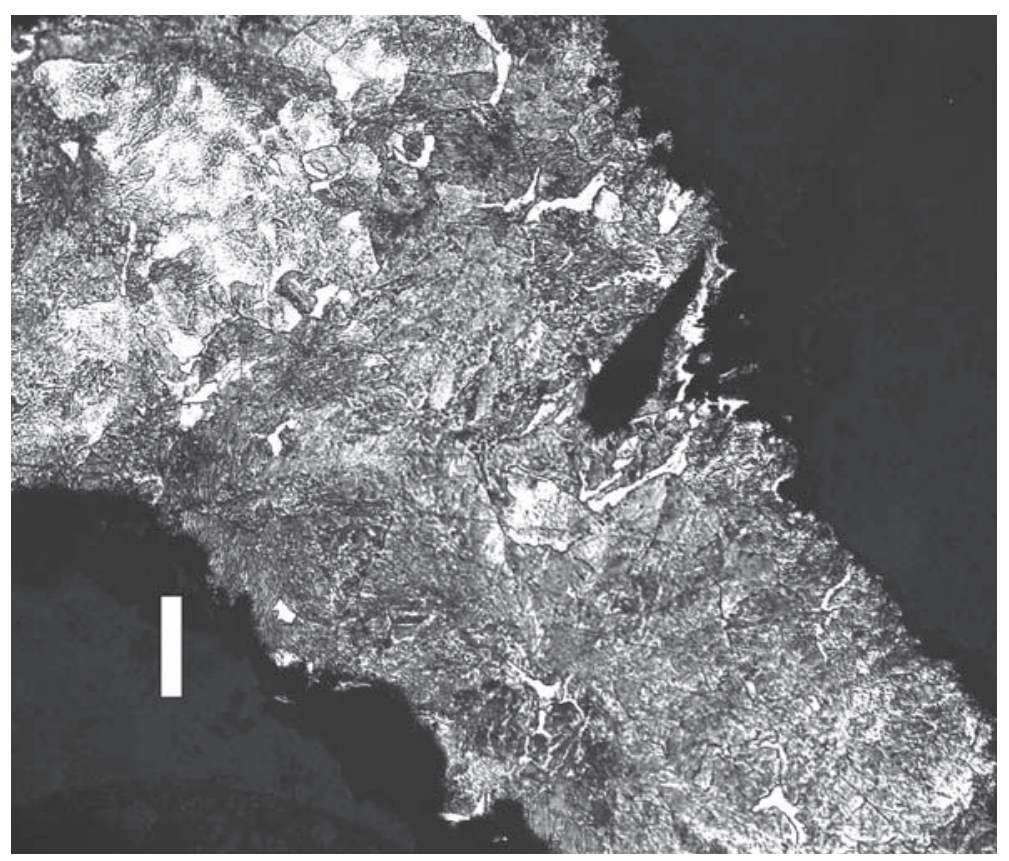

Figure 97. Microstructure of \# C13; pearlite with a little ferrite (scale bar 50 microns). 


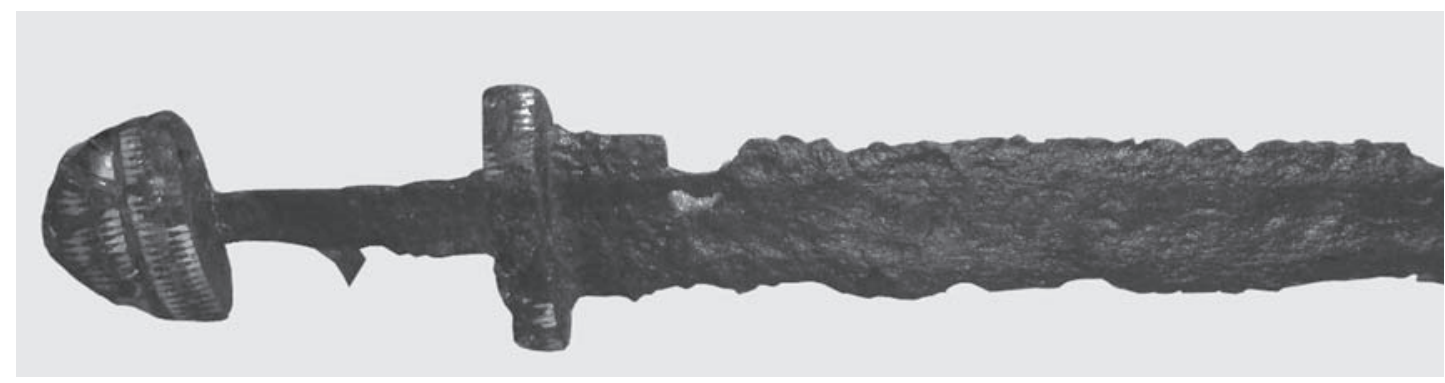

Figure 98. Sword \# C14 from Bergen.

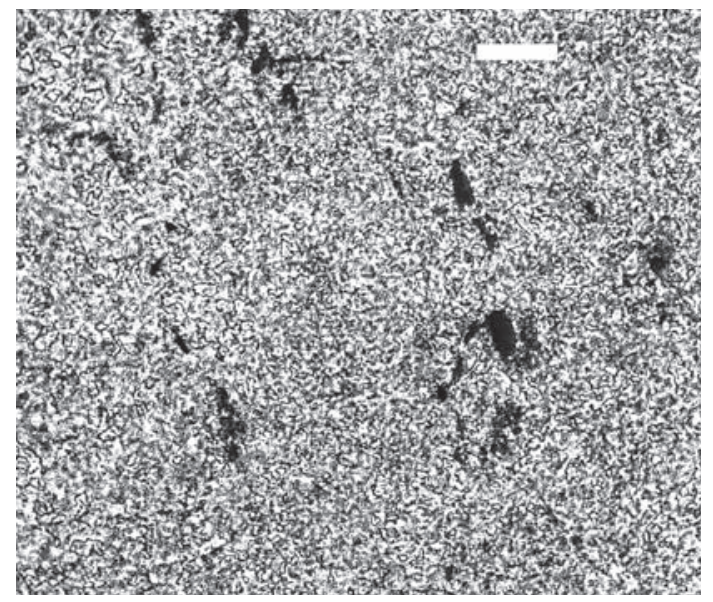

Figure 99. Microstructure of edge of \# C14 (scale bar 50 microns).

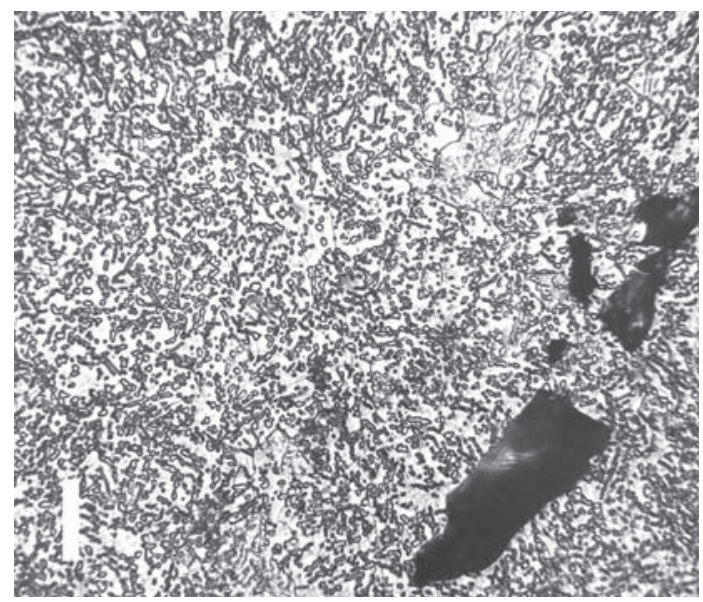

Figure 100. Microstructure of \# C14: ferrite and cementite (scale bar 10 microns).

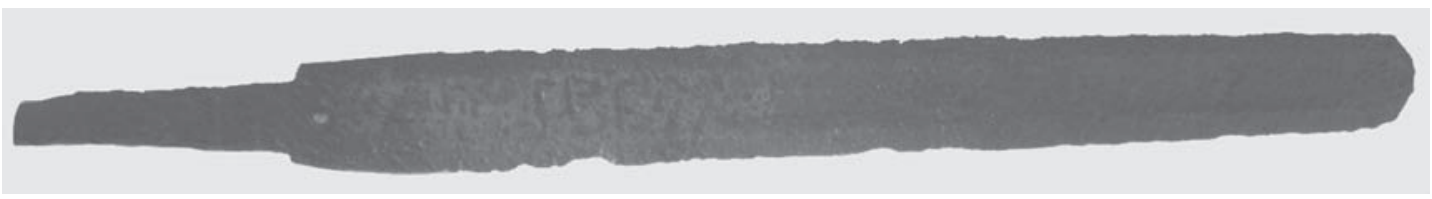

Figure 101. Sword \# D1 from Tyrväntö.

Figure 102. Microstructure of \# D1 (scale bar = 50 microns).

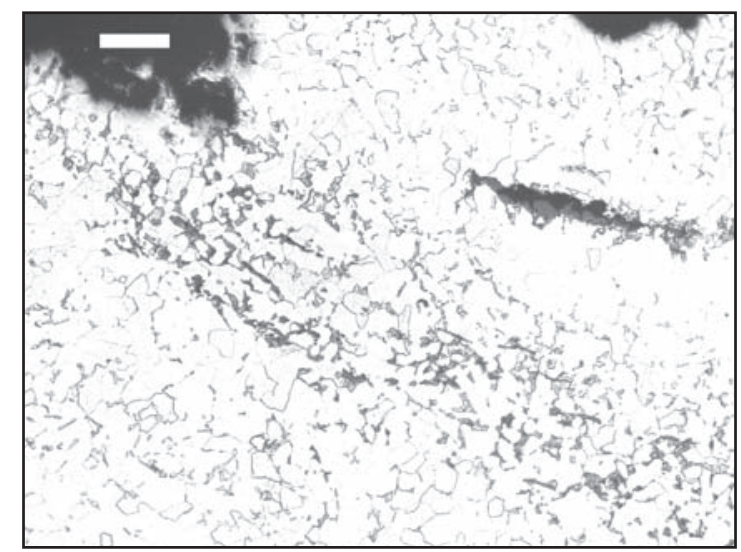




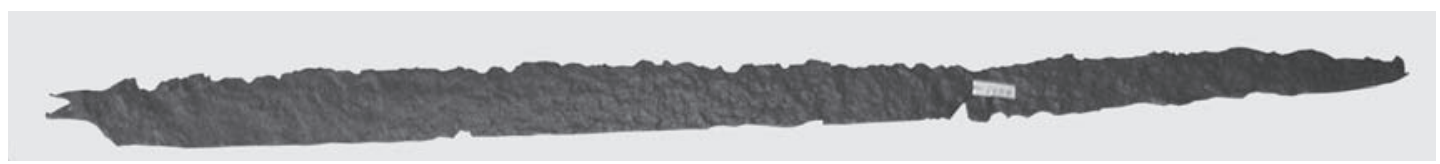

Figure 103. (Remains of) sword \# D2 from Bergen.

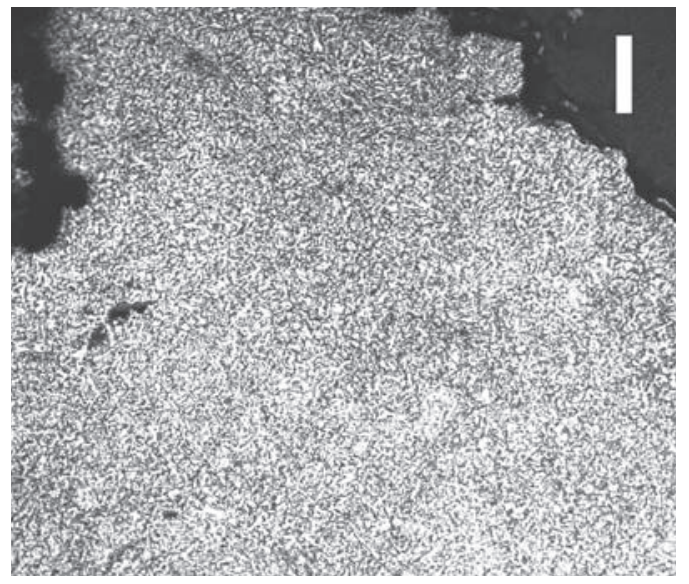

Figure 104. Microstructure of \# D2 (scale bar = 50 microns).

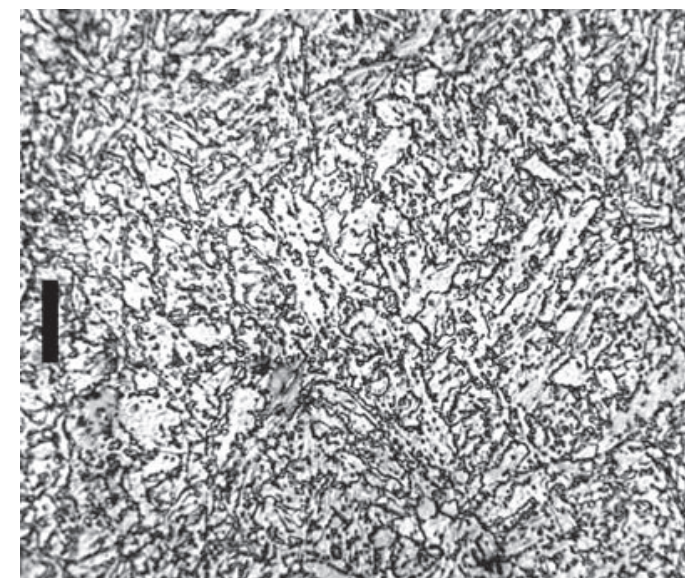

Figure 105. Microstructure of \# D2: tempered martensite or bainite (scale bar $=10$ microns).

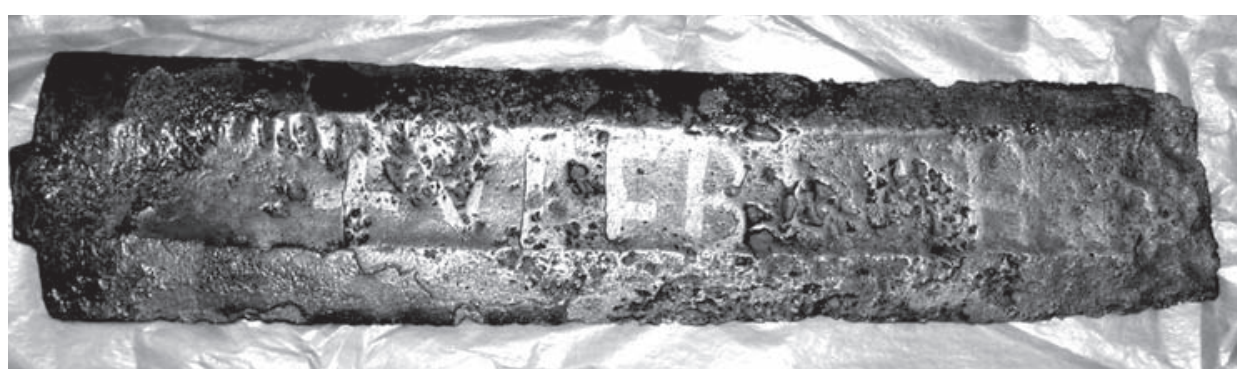

Figure 106. Remains of sword \# D3 with inscription.

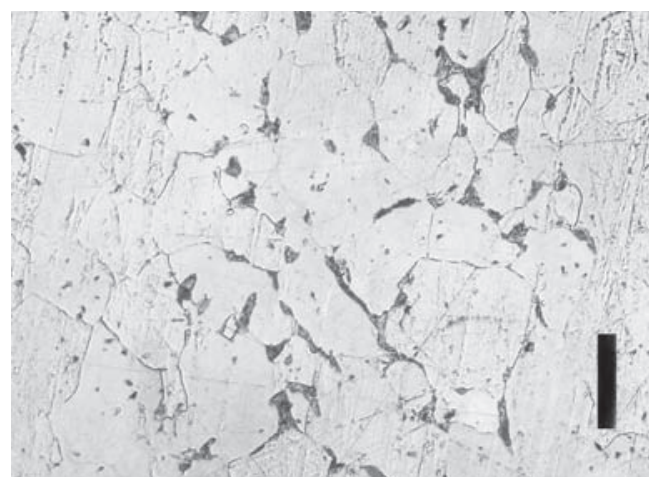

Figure 107. Microstructure of \# D3 (scale bar 50 microns).

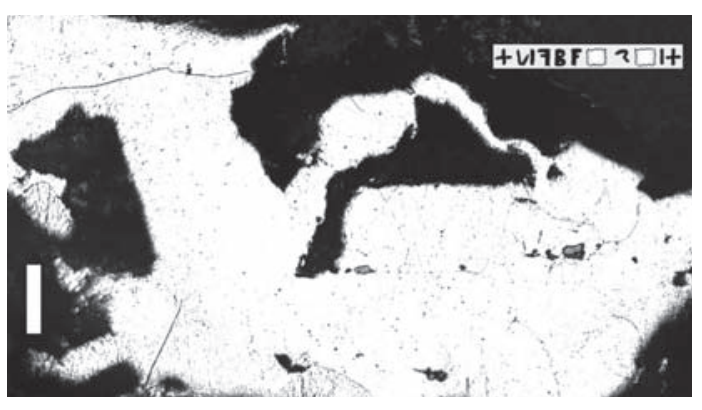

Figure 108. Microstructure of \# D4 (inset inscription). 


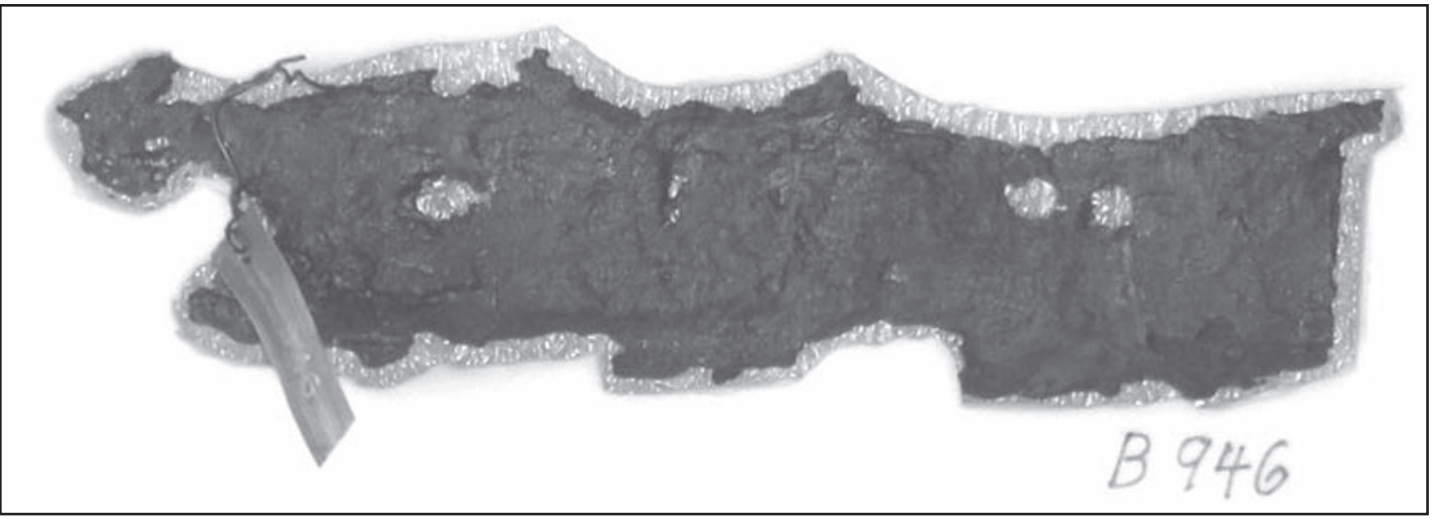

Figure 109. Fragment of sword \# D5 in Bergen.
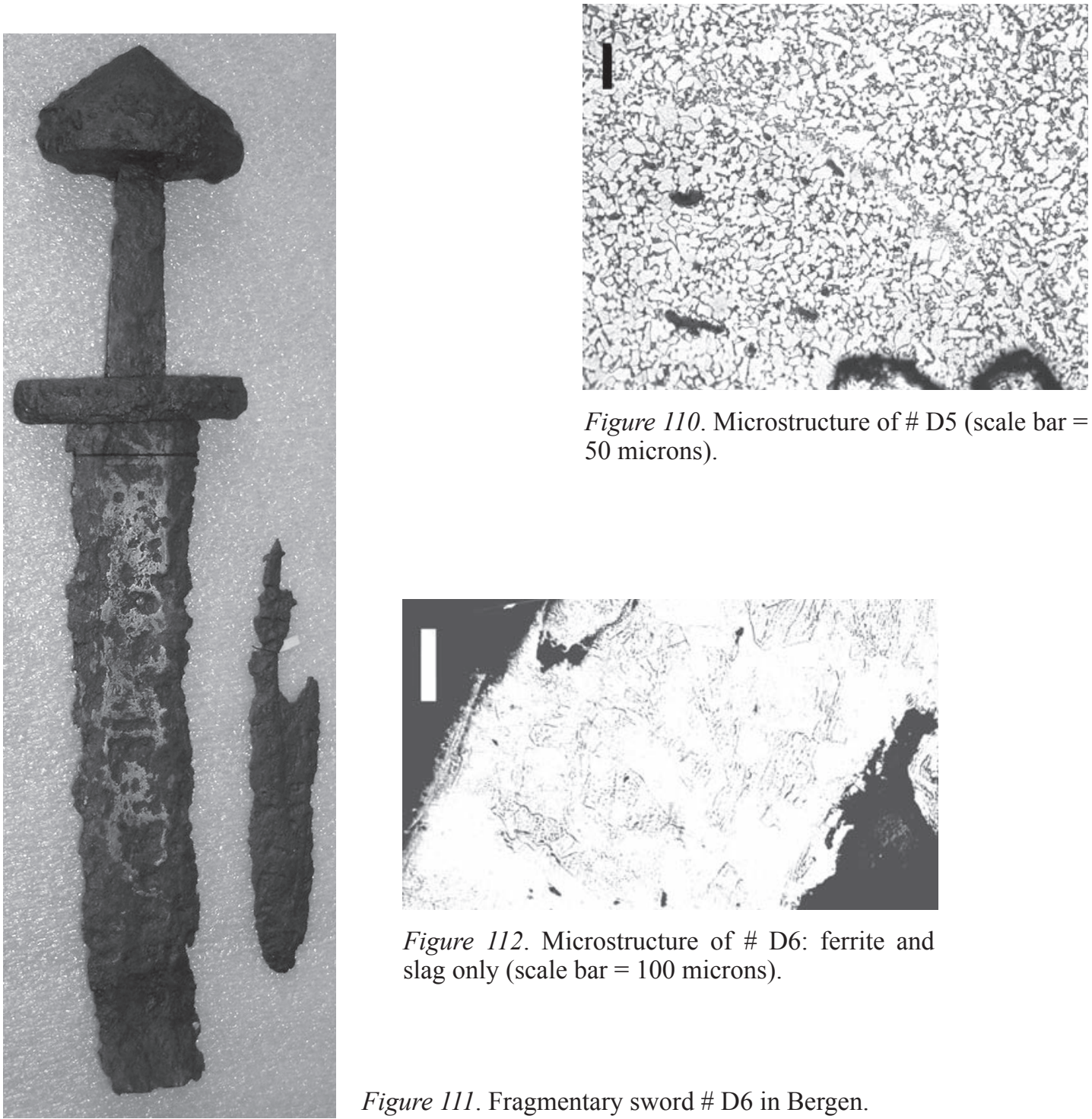

Figure 110. Microstructure of \# D5 (scale bar = 50 microns).

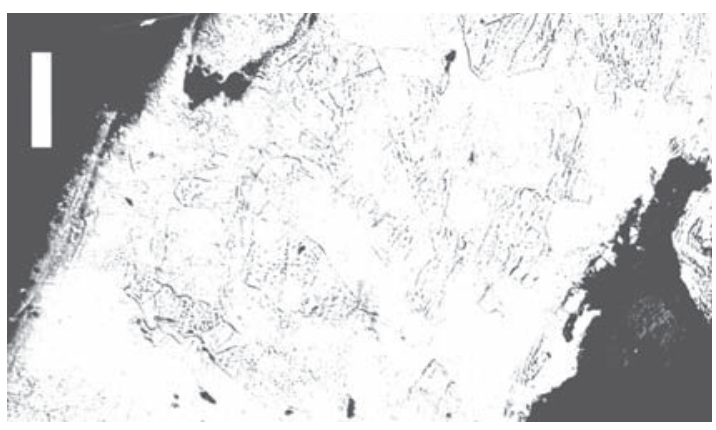

Figure 112. Microstructure of \# D6: ferrite and slag only (scale bar $=100$ microns).

Figure 111. Fragmentary sword \# D6 in Bergen. 


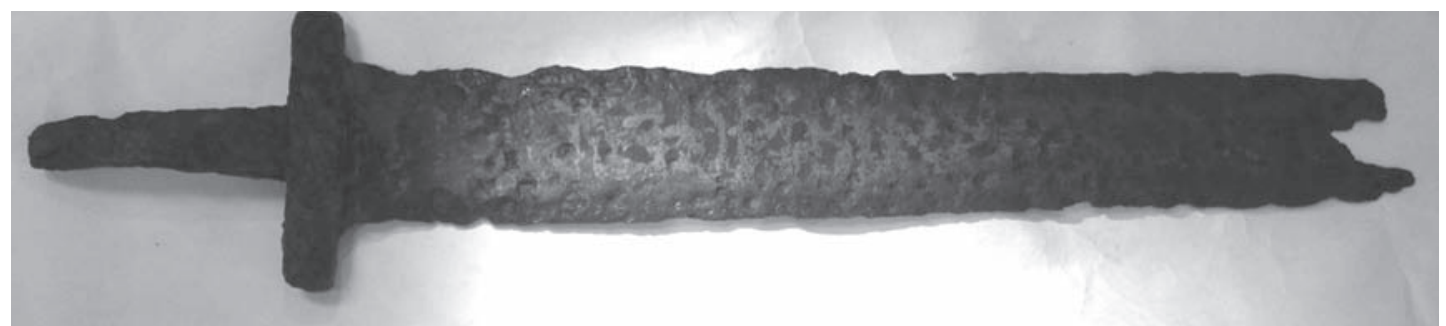

Figure 113. Fragmentary sword \# D7 in Helsinki.
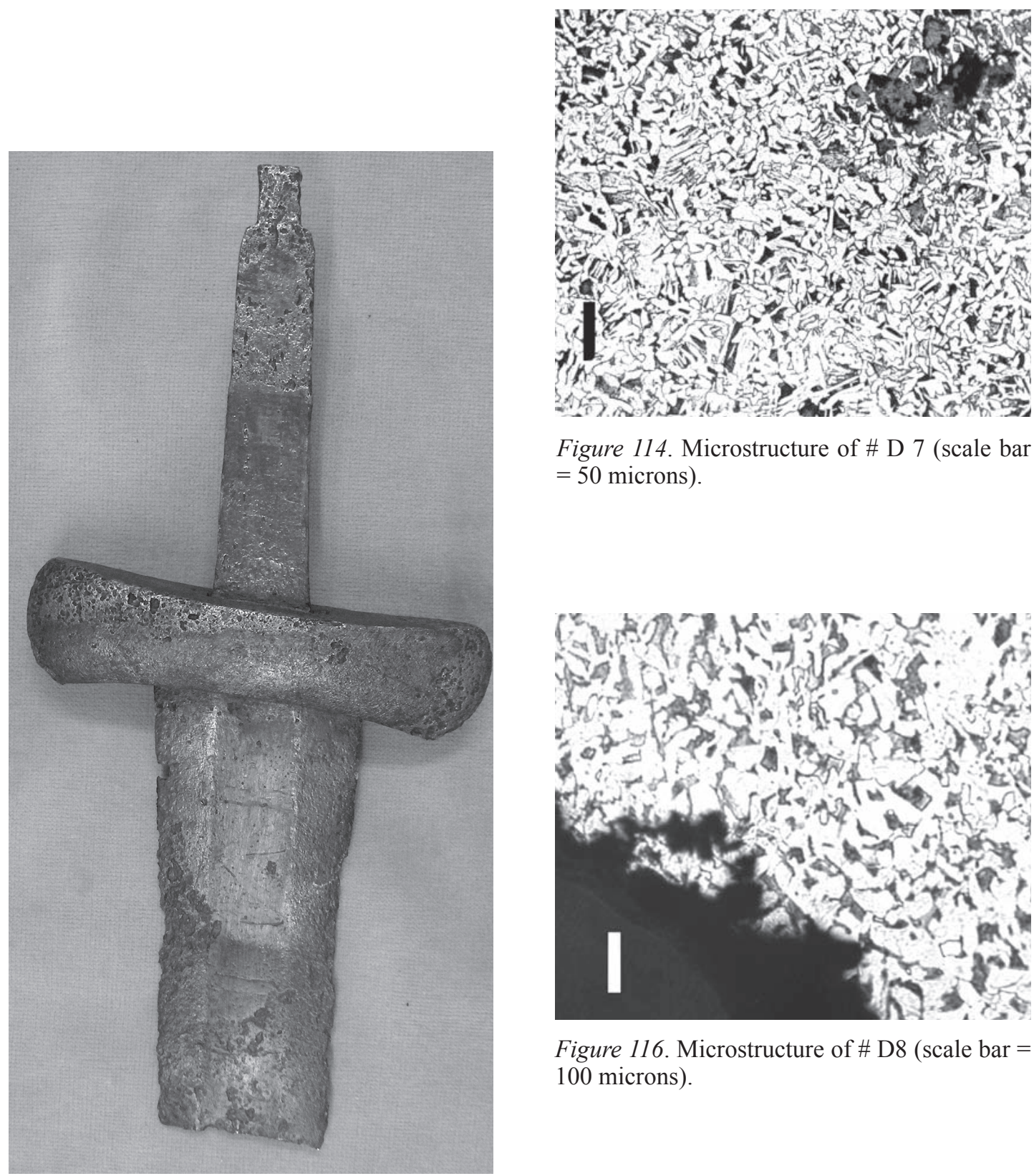

Figure 114. Microstructure of \# D 7 (scale bar $=50$ microns).

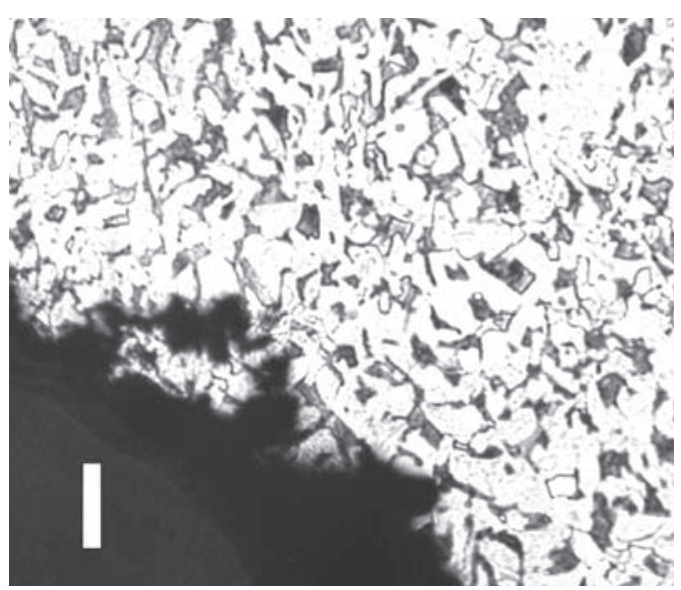

Figure 116. Microstructure of \# D8 (scale bar = 100 microns).

Figure 115. Remains of sword \# D8 from Kokemäki. 


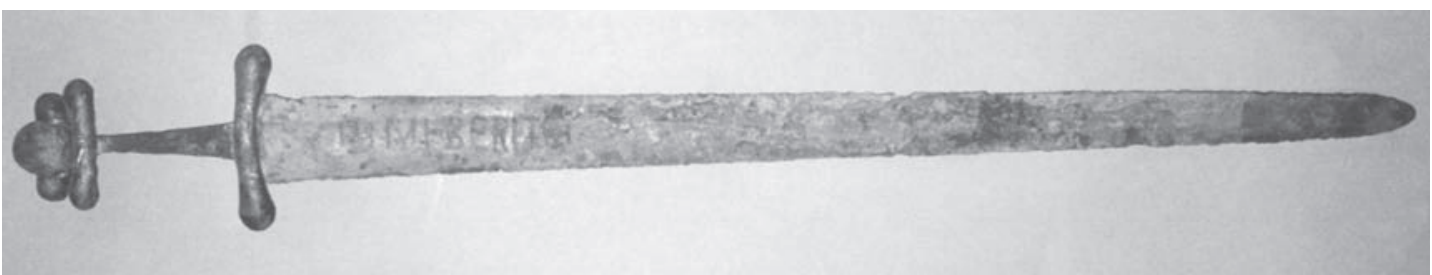

Figure 117. Sword \# D9.
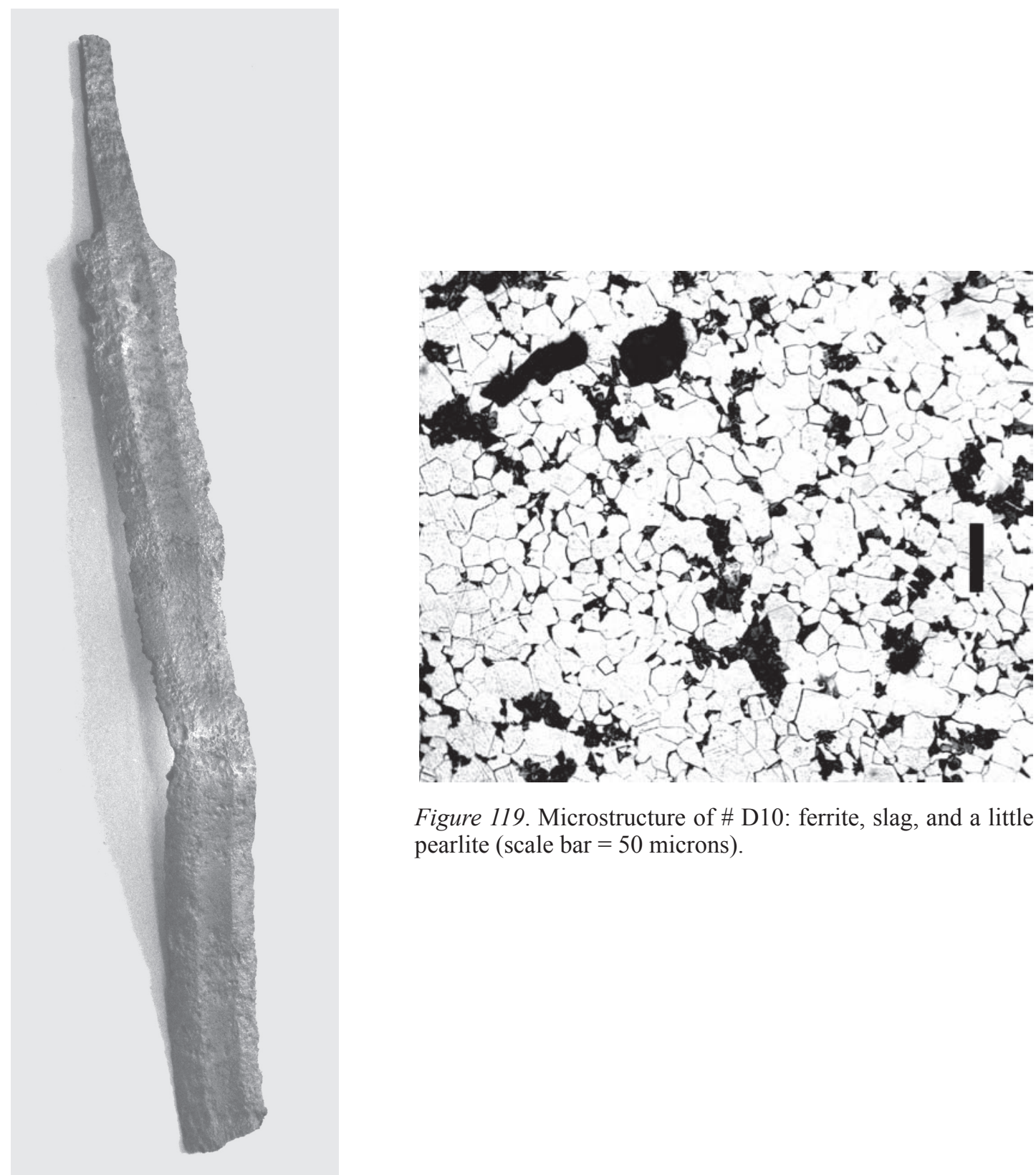

Figure 119. Microstructure of \# D10: ferrite, slag, and a little pearlite (scale bar $=50$ microns).

Figure 118. Fragmentary blade \# D10 from Saaremaa. 


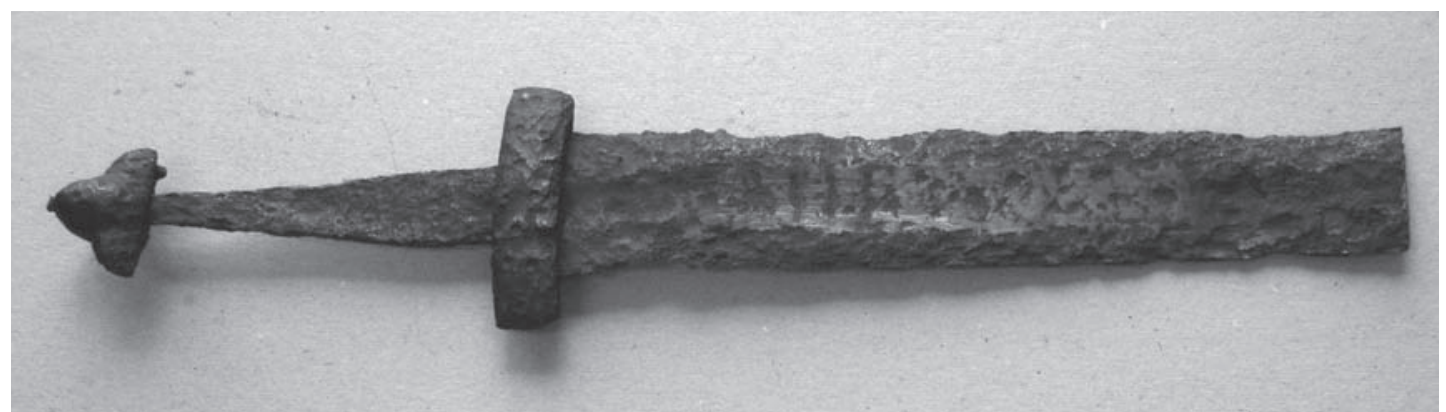

Figure 120. Sword \# D11 from Randvere.
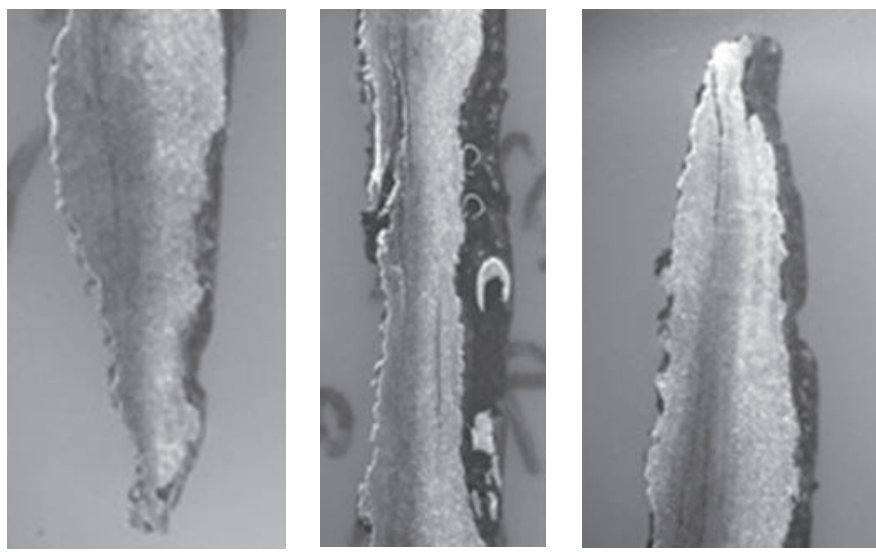

Figure 121. Section of sword \# D 11 ( blade width $38.5 \mathrm{~mm}$ ).

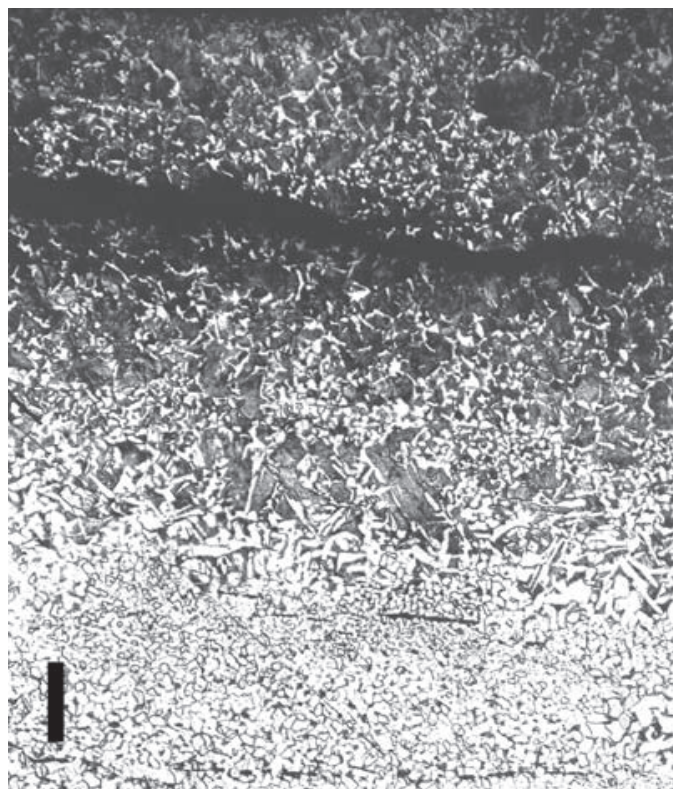

Figure 122. Microstructure of \# D11 (scale bar $=100$ microns). 


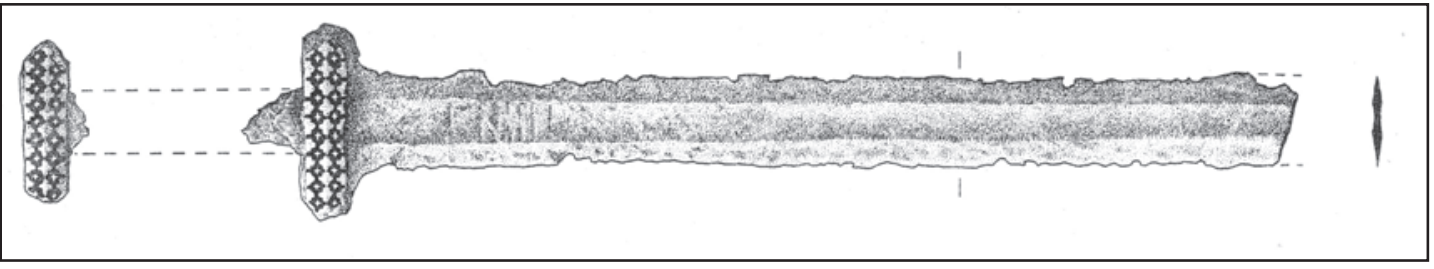

Figure 123. Sword from Donnybrook. \# E.1

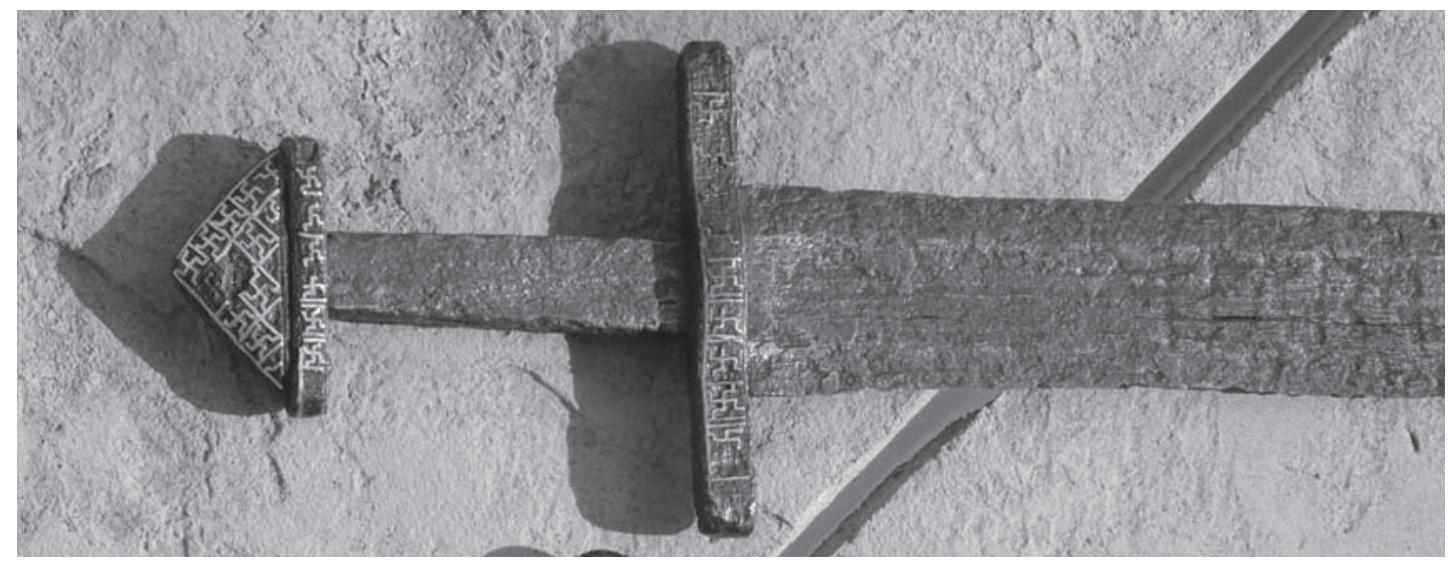

Figure 124. Sword with silver-inlaid hilt \# E.3.

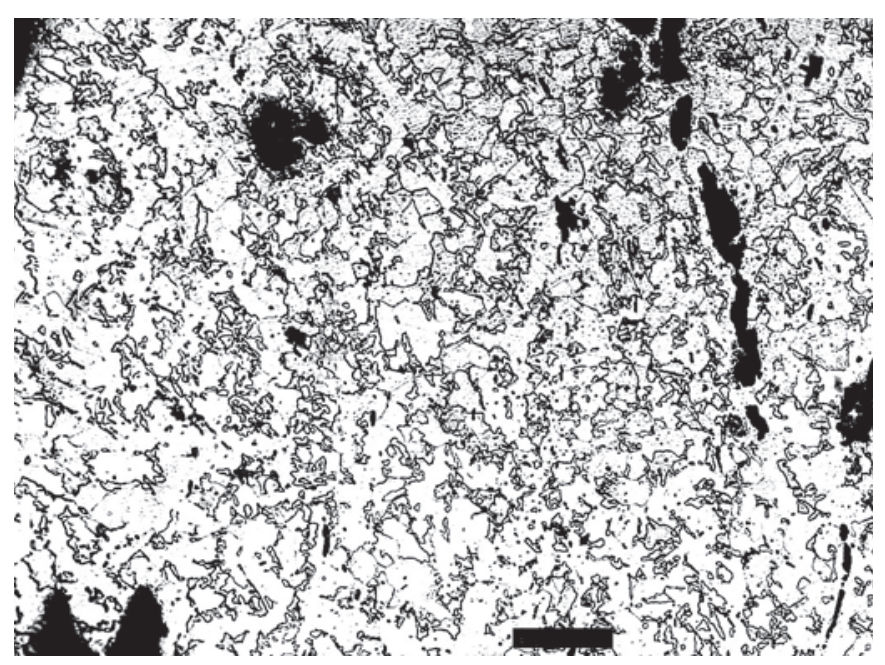

Figure 125. Microstructure of the edge of sword \# E.3: pearlite and irregular inclusions (scale bar $=50$ microns). 


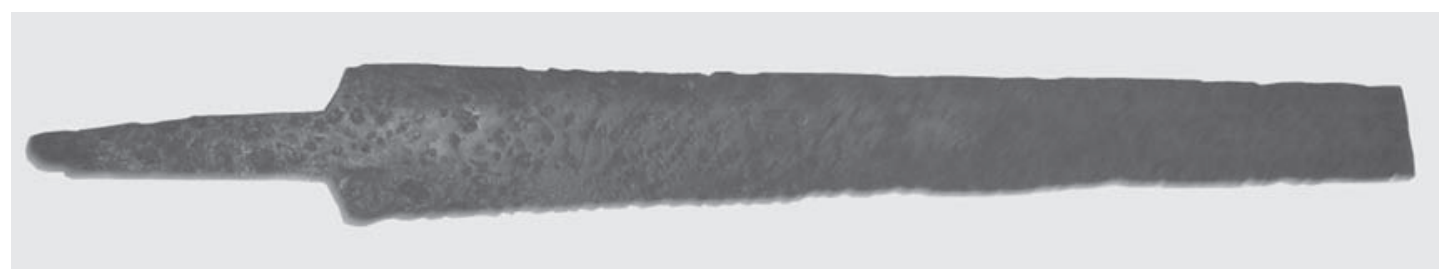

Figure 126. Sword \# E.4 Helsinki 8911 (sword from Mynämäki).

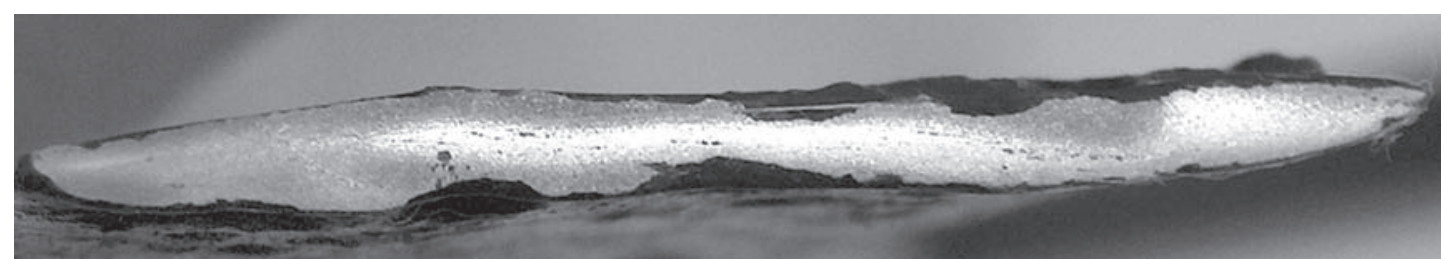

Figure 127. Cross section of sword 8911 (the blade is $42 \mathrm{~mm}$ in width): the dark areas are pearlitic, and the light areas ferritic. Several pieces of iron and steel have been welded together and then forged into a blade. No attempt at hardening by heat-treatment has been made.

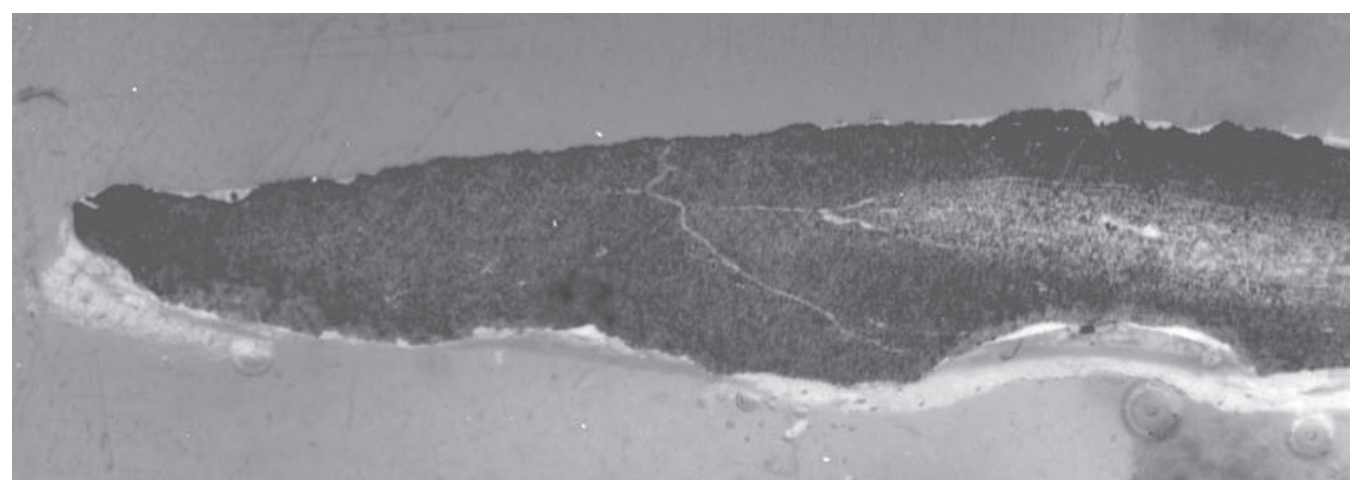

Figure 128. Half-section of one edge of 8911 shows weld lines where three pieces of steel (dark-etching) and one piece of iron (lighter-etching) have been joined together here.

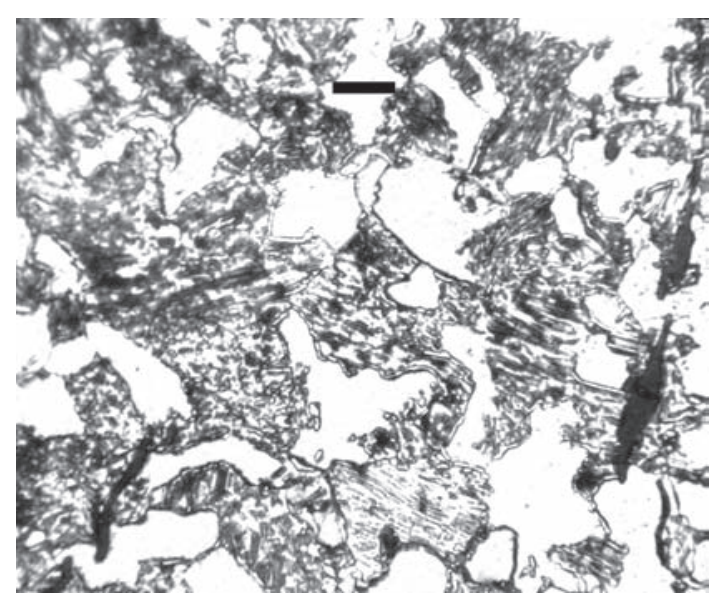

Figure 129. Microstructure of edge of sword 8911 (scale bar $=10$ microns). 

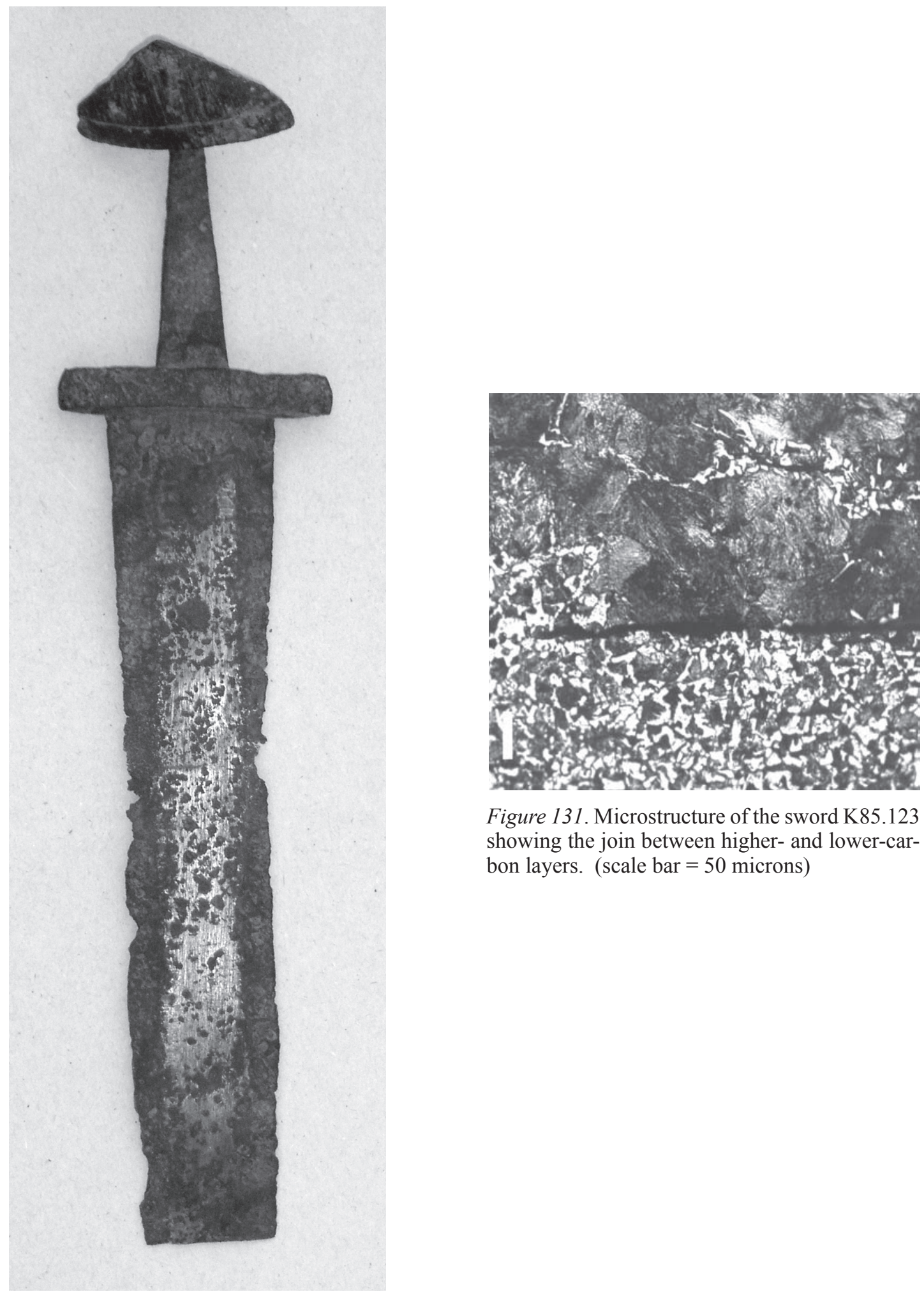

Figure 131. Microstructure of the sword K85.123 showing the join between higher- and lower-carbon layers. (scale bar $=50$ microns)

Figure 130. Sword \# E.5 from Saaremaa K85.123. 


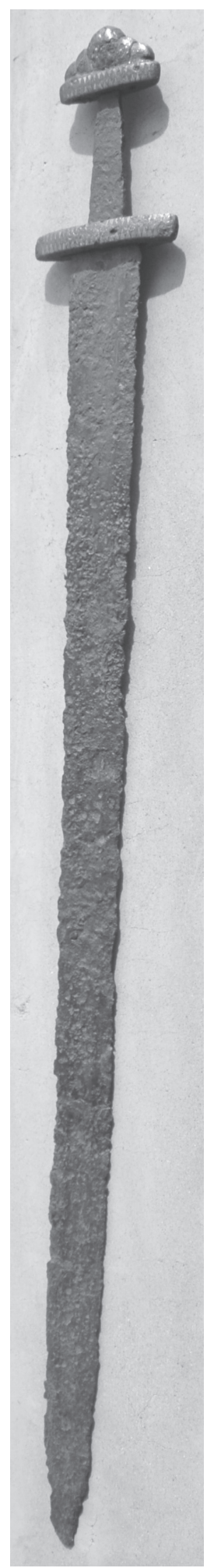

Figure 132. Sword \# E.6 (from a private collection).

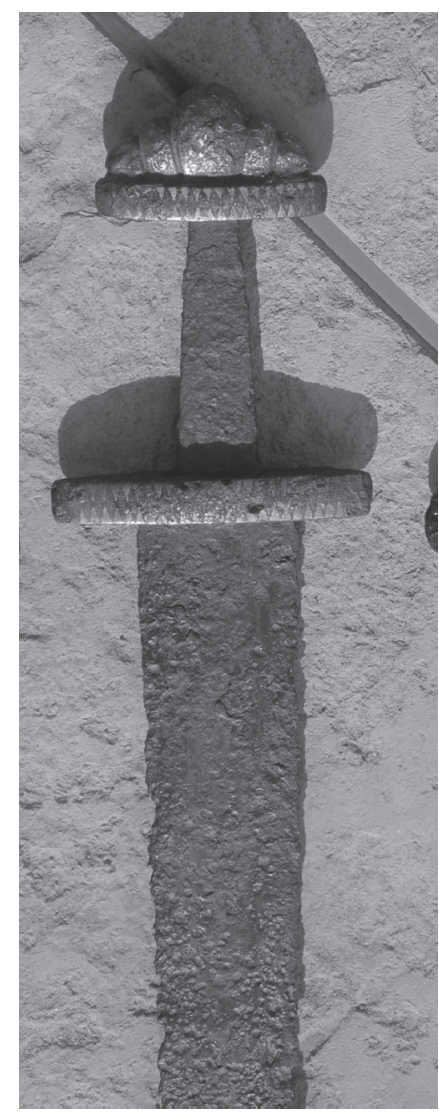

Figure 133. hilt of sword \# E.6.

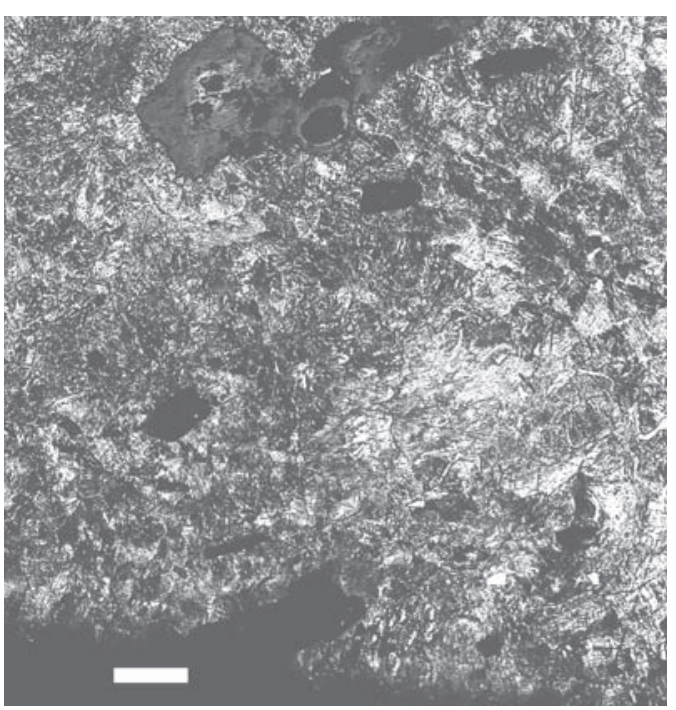

Figure 134. Microstructure of a sample from the edge of sword \# E.6: pearlite and irregular inclusions (scale $\mathrm{bar}=50$ microns). 


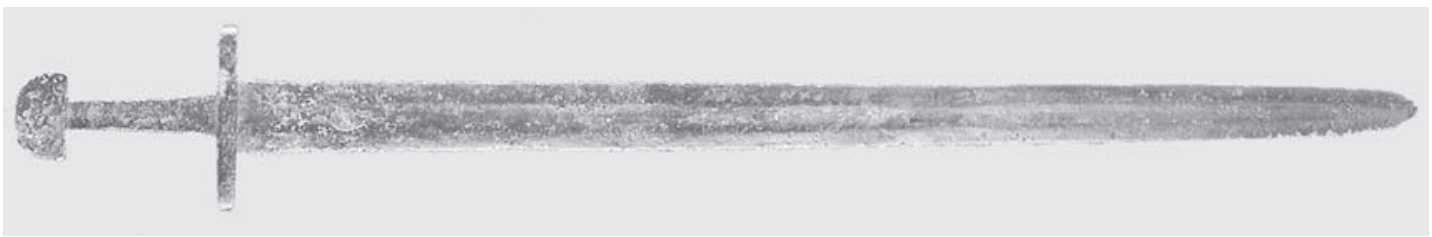

Figure 135. Sword \# E.7 (from a private collection, formerly in the Gwynn collection)

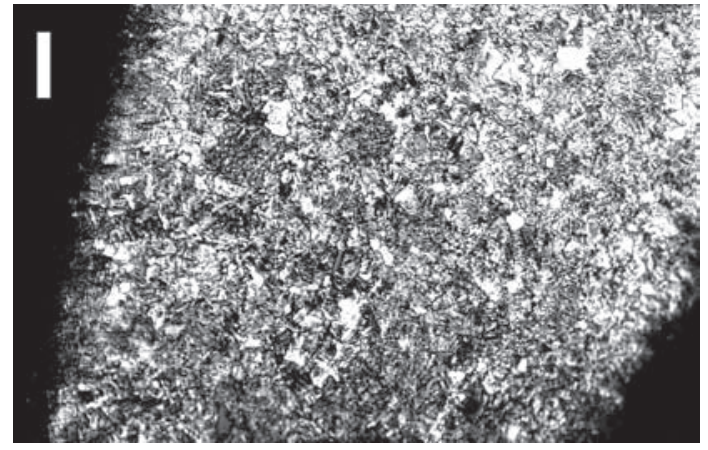

Figure 136. Microstructure of a sample from the edge of sword \# E.7 (scale bar $=50$ microns).

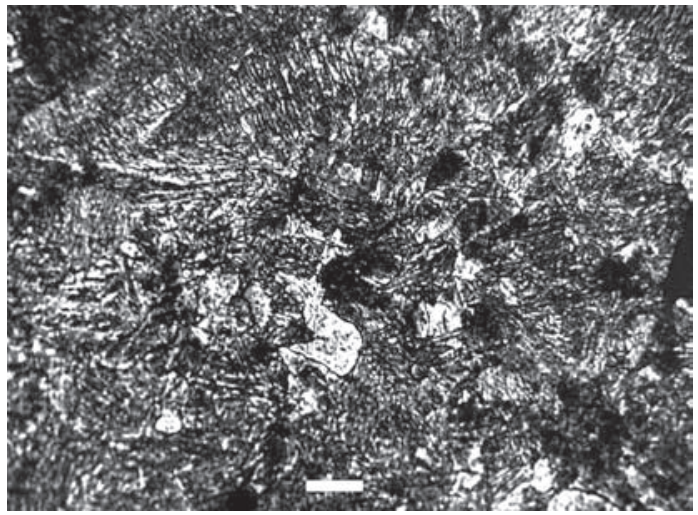

Figure 137. Microstructure of a sample from the edge of $\mathrm{X}$ : pearlite and irresolvable carbides. (scale bar $=10$ microns).

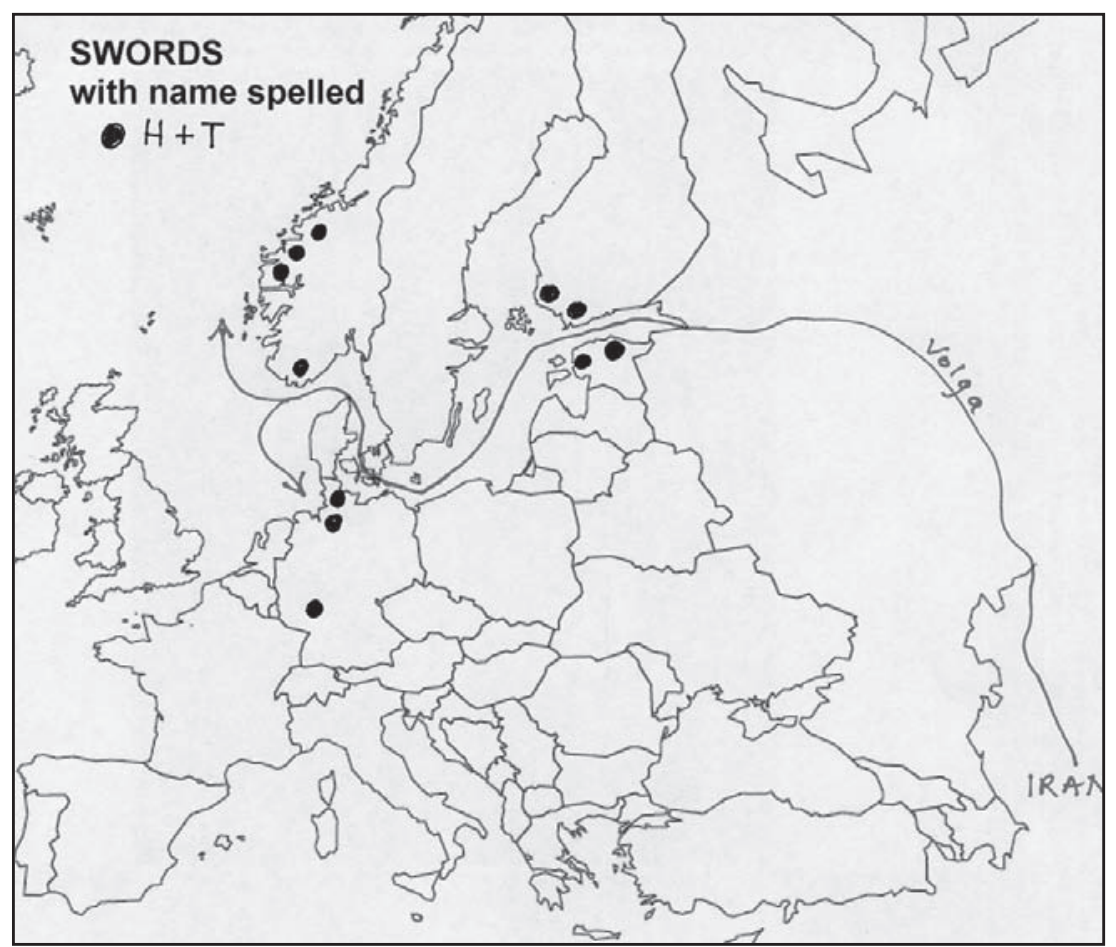

Figure 138. Map showing location of Group A swords with spelling of maker's name +VLFBERH+T 